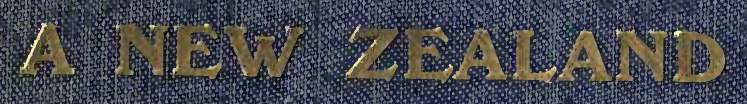

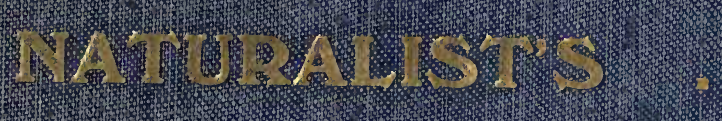

\title{
CALOWDAR
}




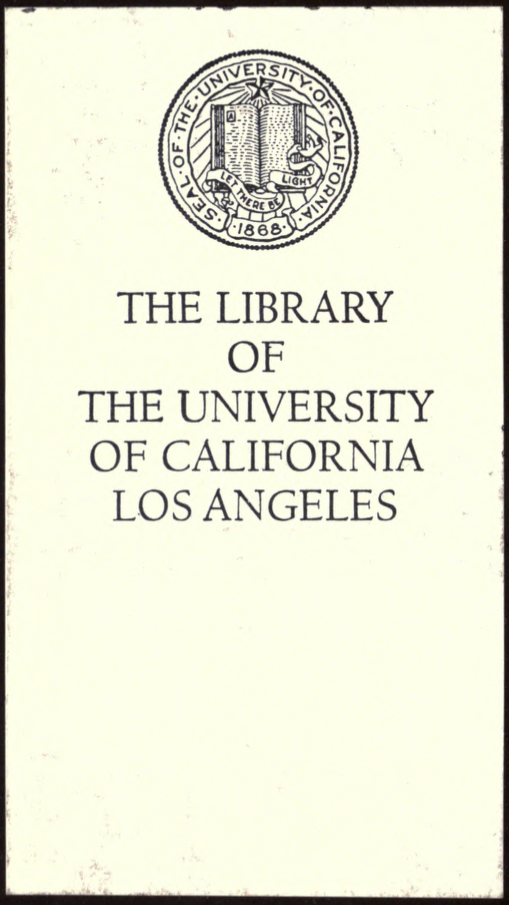


- $-\infty+\infty-\infty$ 



\section{A New Zealand}

Naturalist's Calendar. 


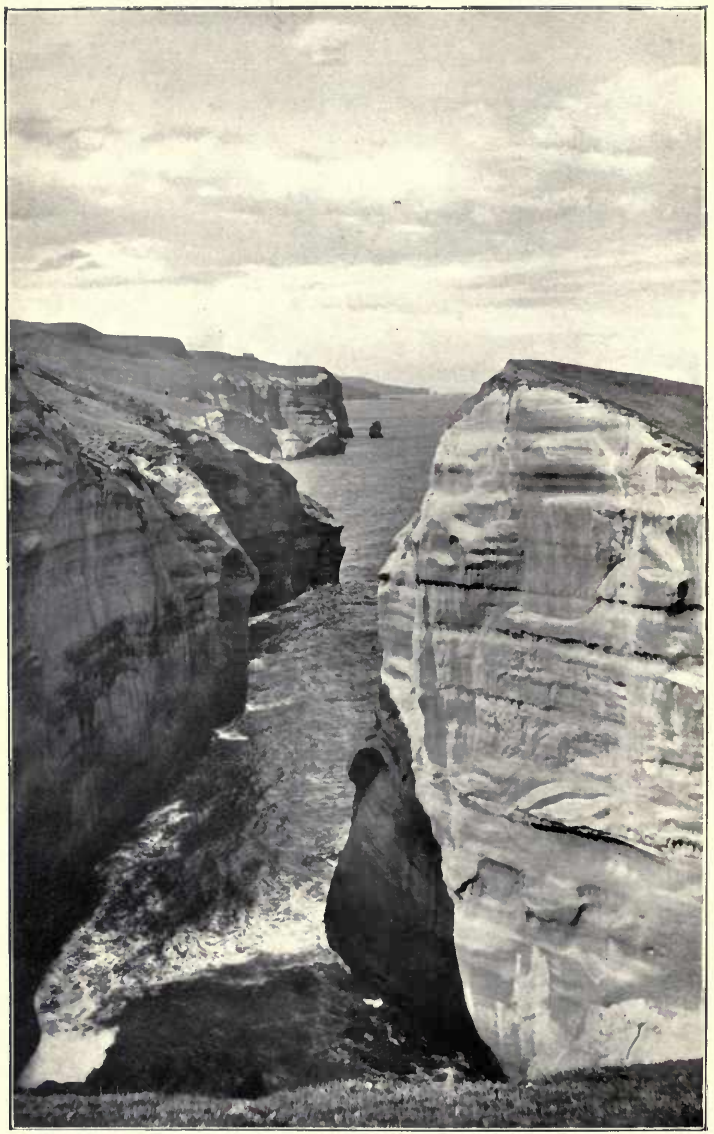

CI.IFFS AT SEAVIEIV SHOWING ACTION OF THE SEA ON THE SANDSTONF. 


\section{A New Zealand}

Naturalist's Calendar

.. AND ...

Notes by the Wayside

BY

GEO. M. THOMSON

F.L.S., F.C.S.

DUNEDIN :

R. J. STARK \& CO.

1909

I'HE LBRAKY UNVERSITY OF CALIFOMATI LOS ANGELES 



\section{PREFACE.}

IN the course of many a ramble throughout New Zealand, and especially in the neighbourhood of this berutifully situated toron which it has been my lot to dhell near for over thirty years, in my claily walks through its finely wooded Toun Belt und suburbs, and in my own garden, I have tried to keep my cyes open to the beanties of Nature. I have recorcled, too, the facts and incidents which interested we, and eventually I put together the notes which I hat made in a series of articles contributed to the columns of the "Otago Duity Times." These articles did not profess to teach anything new; they rather sought to tell achat had interested the voriter, and what he thought would perhaps interest others. They met with more commendation than it seemed to me that they deserved. And it is in response to suggestions from various quarters that they are now isswed in book form, even though I am selt wove-with the pessimist of old-that "of making many books there is no enul."

This little book will be justified if it leads any to look on the common things of Nature with rencmed interest, and to find pleasure in forgotten fields.

I desire in a very special degree to thank M.J. Croshy Smith, F.L.S., of Invercorgill, and my brother, MrJ. C. Thomson, for the photographs used in the illustration of this little book.

DUNEDIN, N.Z. 



\section{LIST OF ILLUSTRATIONS.}

Cliffs at Seaview, showing action of Sea on the Sandstone Frontispiece Clematis indivisa - facing page I Clematis fœtida - $\quad$ - $\quad$ - $\quad$ - $\quad$ - $\quad$ - $\quad$ - page 4 Fuchsia excorticata - $\quad$ - $\quad$ - $\quad$ - $\quad$ - $\quad$ -, 22 Tutu (Coriaria ruscifolia) - $\quad$ - $\quad$ - $\quad$ - $\quad$ - $\quad$ - $\quad$, 28

Mesembryanthemum australe $\quad$ - $\quad$ - $\quad$ - $\quad$ - $\quad$, 33

Plagianthus (Gaya Lyallii) - $\quad$ - $\quad$ - $\quad$ - $\quad$ - $\quad$ - $\quad$ -, 45

Kamai (Weinmannia racemosa) - $\quad$ - $\quad$ - $\quad$ - $\quad$ - $\quad$, 46

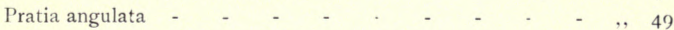

A Common Blue Orchid (Thelymitra pulchella) - - - _ , , 50

A Bush Scene with Small Tree Ferns - _ _ _ _ _ _, 64

Mesembryanthemum australe - $\quad$ - $\quad$ - $\quad$ _ , I14

A Long-Leaved Heath (Dracophyllum longifolium) - - , , I2I

Kowhai (Sophora tetraptera) - - - _ - - _ , I24

Scarlet Mistletoe (Loranthus Colensoi) - _ _ _ _ _ , I I 27

Coprosma Cunninghamii - _ _ _ _ _ _ _ , , I44

A Bush Lawyer or Bramble (Rubus australis), a slender-

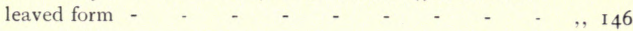

Claytonia australasica - $\quad$ - $\quad$ - $\quad-\quad, 158$

Astelia nervosa, in fruit - _ _ _ _ - , - 16 I

Native Violets (Viola Cunninghamii) - _ _ _ _ _ , , 179

Mako-mako (Aristotelia racemosa) - _ _ _ _ _ , I8I

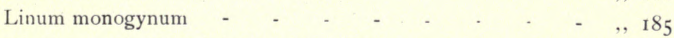

Boulders on the Beach in Moeraki Bay - _ - _ _ _ , 192

Cliffs at Seaview, showing action of Sea on the Sandstone - ,, 200

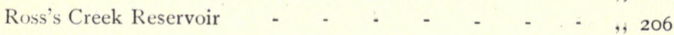

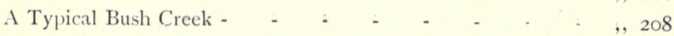




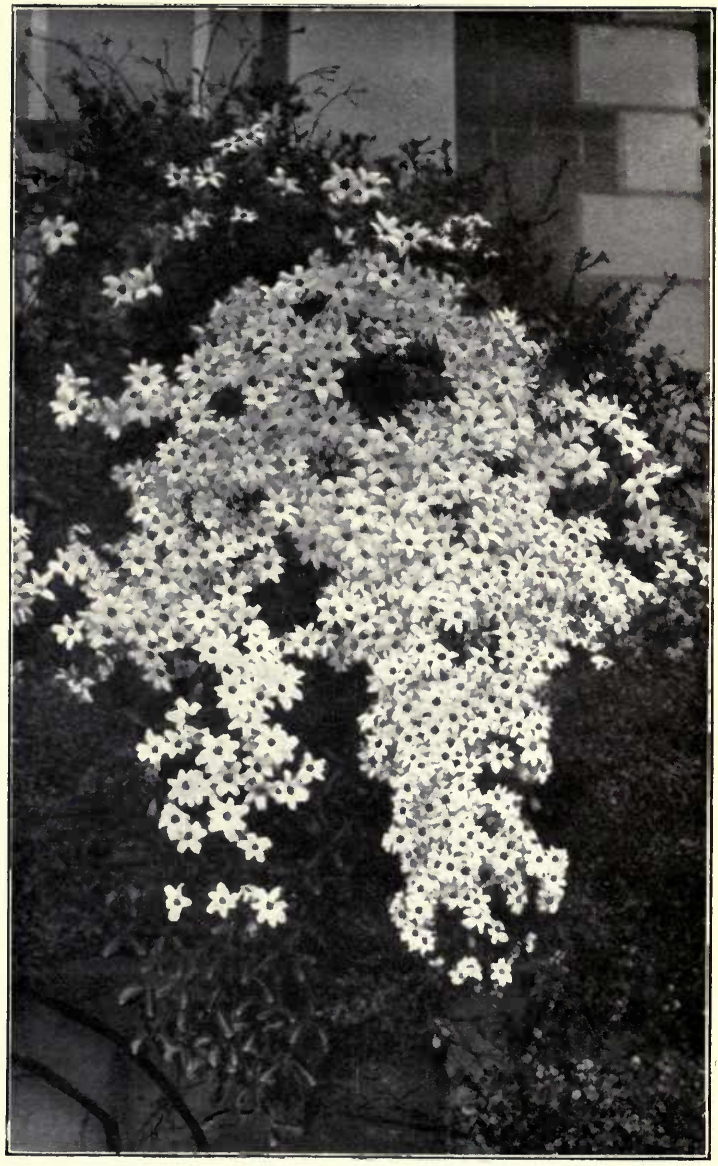

Clemalis indivisa. 


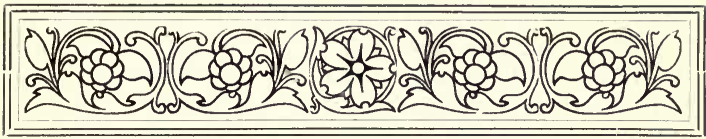

\section{A NEW ZEALAND}

\section{NATURALIST'S CALENDAR.}

\section{Chapter I.-November.}

I.

T $\mathbf{T}$ is a lovely spring morning with a quiet balmy feeling 1 in the air, and all nature seems refreshed with the shower's which fell during the night. It is too fine to stay indoors, and there is much to admire and enjoy in the garden. The spring flowers have been so charming, even though the October gales have sadly knocked them about of late. Primroses and all their allies have flowered very profusely. What an interesting device these flowers have to bring about cross-fertilisation!-the "pin-eyed" forms having the button-like stigma projecting from the throat of the corolla on the top of a long style and the stamens placed halfway down the tube, while the thrum-eyed ones have the anthers at the throat and the stigma halfway down the tube on a short style. In Europe, where these flowers are native, they are visited by various kinds of insects, including species of humblebees, which carry the pollen from the short-stamened to the short-styled, and from the long-stamened to the longstyled flowers. In this country these flowers never used to be fertilised naturally till humble-bees were introduced. Now they seed quite freely, and the flower beds if in a clamp aspect and not hoed too rashly will fill with seedling primroses. It ought to be possible now to acclimatise these flowers in suitable localities, provided they are 
left alone and not choked by that most aggressive of naturalised plants the cocksfoot grass. I find that out of 226 specimens of seedling primroses in my garden, 121 are long-styled and $\mathbf{1 0 5}$ are short-styled; while among auriculas the proportion is 25 to 28 . I notice, too, that in some of my seedlings there is a tendency for the stamens to be suppressed. Wherever this occurred the throat of the corolla was five-lobed, as if a corona or a five-angled cup was being developed. This sport might with cultivation lead to the establishment of a very interesting and pretty variety.

Over the front of the verandah, and creeping up to the drawing-room windows, are several plants of the large white-flowered Clematis. This loveliest of our native bush flowers also has two kinds of blossoms, again occurring on different plants, but of different sexes; the male or staminate having six large white sepals and a bunch of numerous stamens, whose greenish-yellow filaments crowned with the pink anthers give such a delicate tint to the flowers, and the smaller, more star-like female or pistillate blossoms, with a single row of imperfect stamens and a central tuft of carpels with long feathery styles. The pistillate flower's are generally greener in hue than the staminate, whose sepals when fully opened are nearly pure white in colour. Both kinds of flowers are extremely conspicuous, not only on account of their size and brilliancy, but also because they are produced in such large masses; but they have no appreciable scent and are apparently destitute of nectar. But if you stand and watch them closely you will see that several kinds of flies, and sometimes some honey-bees, visit them. The latter are perhaps chiefly in search of the pollen which is produced in such profusion, but the former will be seen to thrust their trunks down among the bases of the filaments, where they evidently find something very much to their taste. Each male flower has a great many-from 80 to 100 - stamens, and each anther contains some hundreds of pollen granules. As only one of these granules is required for the fertilisation 
of each ovule, it is evident that thousands of such grains night be eaten by inserts and yet leave more than enough to fertilise all the pistillate flowers. As a matter of fact, in addition to the bees and flies, there are many species of flower-visiting beetles which feed chiefly on pollen, and it is to attract these that so much pollen is produced. Nearly all flower-visiting insects have hairy bodies, to which pollen readily adheres, and in this way the grains are carried from flower to flower.

There is considerable diversity of size in the blossoms of our common clematis, as well as in the character of the foliage, and this has led to its separation by botanists into two species, named respectively Clematis indivisa and $C$. hexasepala. The extreme forms are rather unlike, a fine specimen of the former having flowers as much as four inches across and large undivided leaves, while the litter has smaller leaves, which are more or less cut into, and the flowers are often not half the size; but there are so many intermediate forms that it frequently becomes (lifficult to decide to which to refer any particular specimen.

The mode in which the clematis climbs is both remarkable and interesting. The leaf-stalks in their young stages are extremely sensitive to friction, however slight. A few gentle rubs with a straw on one side will cause the stalk to bend in that direction in the course of a very short time. and if the rubbing be continued the bending will also continue till the stalk has made a turn right round into a loop or circle so as to enclose the irritating body. In this way, if a breath of wind moves the young stalks against the twigs of a tree or any other support in the neighbourhood, they quickly bend round in the direction of the resistant body and thus catch hold of the support. Once they have got hold they soon thicken and strengthen their tissues, in response to a law, common apparently to all living organisus, which causes them to develope new tissue wherever the stimulus of friction or irritation is applied. If a stem of clematis is cut through with a sharp knife and the cut end is examined with a 
good pocket-lens, it will be found that the tissues consist of numerous wedge-shaped bundles of tubes radiating from a small central portion of pith, and separated from each other by delicate layers of soft cellular tissue. The

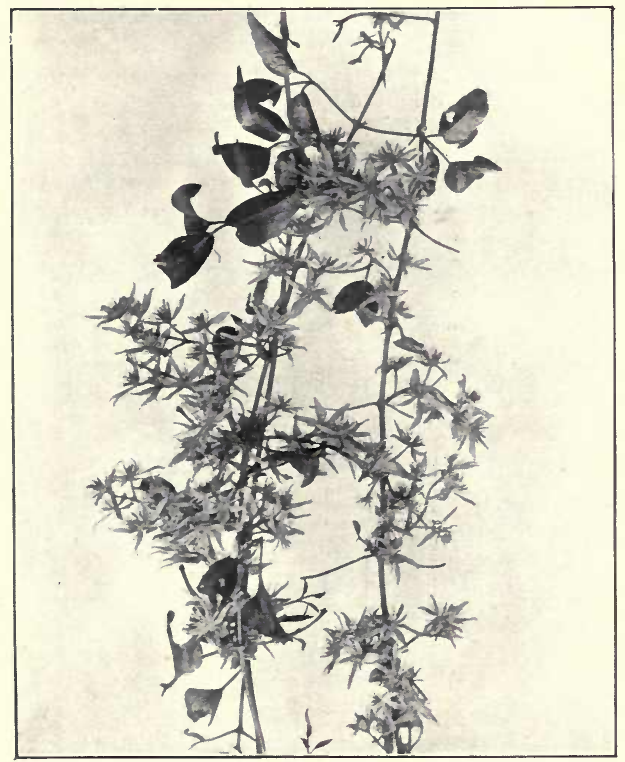

Clematis fotida.

arrangement of the wedges in the circle is not only very beantiful but suggests a combination of great strength and elasticity. Under the microscope the bundles are seen to be formed in great part of rather wide tubes with little pit-like markings on their walls. It is up through these that the fluid nomrishment of the plant is 
drawn, and the size and abundance of these open conduits explains how a plant with such a comparatively slender stem can grow to so great a length as to produce its flowers on the top of the foliage of a tree at a distance often of a hundred feet from the ground.

There is another clematis common about Dunedin which is worth looking at and contrasting with its more showy relative. It is abundant in many parts of the Town Belt, and is easily recognised by its bunches of small greenishyellow flowers, which are rather silky in texture. The individual blossoms are only from one-half to threequarters of an inch in diameter, and the staminate forms have only from twenty to thirty stamens in each. But they differ markedly from the larger form in being fragrant. Many sweet-scented flowers become disagreeable when kept for a time; for instance, hawthorn is very pleasant when the blossoms first open, but afterwards it acquires a rather fishy smell. Something like this must have happened to the specimens of this species which were examined by M. Raoul, who originally described it, for he called it Clematis foetida, a sad misnomer for so fragrant a flower. If you watch the plants on a bright calm and warm day, such as this is, you will observe many bees and flies on the flowers, busy not only eating or gathering pollen but also sipping the nectar from the bases of the stamens and carpels.

A fourth species of clematis, of very peculiar type, occurs somewhat rarely on Wharé Flat, on the farther slopes of Flagstaff Hill. It is appropriately named Clematis afoliata, for it has no leaves in its adult state. The stems are thin and bare, so that the plant appears as a dead specimen; but the young branches have a few small trifoliolate leaves, and it bears flowers of a clull purplish colour which are very fragrant. The individual flowers are not much more than half an inch across, so that the whole plant is very inconspicuous and easily passed by. 


\section{II.}

As I sit here looking over the garden, a black and extremely hairy caterpillar-a little over an inch in length-comes across the footpath with a rapid and yet unconcerned sort of movement, as if disdainful of danger. The way in which it marches over the open and exposed path suggests a confidence bred of hereditary immunity from persecution. Evidently the early bird which catches the worm knows enough to let this caterpillar severely alone. By way of experiment, one was put down on the ground beside a hen with a brood of young chickens. The old bird eyed it cautiously as it crept along the ground, but would not touch it. The chicks came up one after another and took a slight peck at it, but each dropped it instantly. It is common to speak of hereditary instincts to account for the tastes and distastes which animals exhibit, but after all it is, in most cases, probably a matter of education. 'These chickens will most likely remember next time they see a hairy caterpillar that it is not a toothsome morsel nor a desirable mouthful.

If we pick a bit of groundsel and arrest the traveller on the march, it will walk on to the plant, and can be examined at leisure. Looking at it through a pocket lens-a most useful and indeed necessary companion for anyone who desires to study the beauties and wonders of nature, - the hairs are seen to arise in tufts from little shining black or blue-black warts with which the segments of the body are ornamented. Between these warts are small red spots arranged in parallel rows, and contrasting in a very striking manner with the dark ground colour of the body. These caterpillars are very easily reared, and it is a capital object lesson for any child to try the experiment. A cardboard box with glass top serves very well for a vivarium in which half a dozen caterpillar's may be confined. They eat groundsel greedily, and only need to have fresh leaves given to them every twenty-four hours, and to have 
their box kept clean. After a few weeks the insects cease to feed, and, climbing into the corners of their box, will in the course of a day or two spin a slight web of silk and hair within which the pupa will be partially hidden. In this state it will remain apparently dormant for from four to six weeks, when from each case there will emerge a fine moth. This insect is one of the commonest of our moths, and is usually mistaken for a butterfly. Its wings are black with two or three white spots on each, while the body is black crossed with bright yellow stripes, making a very conspicuous combination of colour. The slow fluttering flight and the complete want of concealment of this moth show that the perfect iusect, like the larva, must be distasteful to birds. The moths are common throughout the summer and autumn, and are to be met with even into winter if the season is mild, and two generations seem to be reared during each season. They visit many kinds of open flowers, and slowly dip their long trunks into the nectaries to suck up the sweet fluid contained in them. The technical name of Nyctemera annulata-so called from the golden-yellow rings which encircle the bodyis given to this pretty insect.

Of late years there has been a very remarkable in crease in the abundance of these insects, especially in the sonthern end of this island, and this is apparently due to the great abundance of rag-wort (Senecio Jacobea), which has become such a serious pest in the south. Armies of the caterpillar are sometimes met with during the month of November, followed later by myriads of noths.

\section{III.}

In most of the damp and untrodden parts of the bush there may be found at the present time numerous examples of a little orchid of very singular appearance. On a spraysprinkled stone at the side of the bed of one of our mountain streams, or on the sloping moss-covered bank, may be seen delicate heart-shaped or kidney-shaped leaves an inch 
across or less, and apparently sitting on each is a large spider with long legs. The resemblance is only very superficial, but it is sufficiently strong to give that impression at a little distance. On coming closer it is found to be due to a flower of rather peculiar shape.

To anyone unacquainted with the subject the peculiarity of its structure will be most readily explained by contrasting it with some other better-known flower. 'Thus, if we take a Blue-bell (wood hyacinth) in our hand we find that the flower is made up of six blue leaves - the perianth leavesinside of which are six stamens, and inside of these a small globe-like ovary with a three-branched style and stigma. The parts are quite easily made out, even without the aid of a pocket lens. The perianth leaves in many flowers are distinguishable into an outer set of sepals, forming the ealyx, and an inner set of petals, forming the corolla, but in the blue-bell their position is the only index of what they are. The three which are outermost in the bud are the sepals, and they are usually a little broader than the three petals which they partially enclose. liach stamen has on the top of its stalk a club-shaped head or anther which opens when mature and permits a quantity of pale blue waxy pollen grains to escape. When these get on to the stigma, either of their own or another flower of the same kind, they usually bring about fertilisation of the ovules, and this leads to production of the seed. These facts are familiar to most persons who know anything about plants. Now, if we compare our little orchid flower with the bluebell we can trace out certain resemblances, together with very numerous dissimilarities. The six perianth leaves are present, but they are very unlike one another. At the back of the flower is one rather large sepal, which is greenish in colour but more or less striped and spotted with purple, this arches over the rest of the flower like a helmet, and shuts in all but the front. Facing it is a large purple lower lip, which is the inner petal or labellum. These two parts form the chief portion of the flower. The other four perianth leaves, two sepals and two petals, are lengthened out into long slender tails, and it is these which 
give the flower its peculiar spider-like appearance. Inside the flower we search in vain for the six stamens and the three styles; they are not developed. Yet they can be traced by those who are expert in plant dissection, though it is questionable whether they could be found even by the cleverest manipulator in such a small species as the one now under consideration.

What we do find is a small column at the base of the flower having at its upper part a single stamen, just in front of which is a minute sticky point called the rostellum $o r$ beak, and below that two small sticky depressions which represent two stigmas. In most flowers pollen consists of small grains which are separate from each other, although in fuchsia, rhododendron, and a few other common flowers these grains may be loosely tied together by threads of viscine. But in orchids the pollen is fastened into little roundish or pear-shaped masses called pollinia. The reason, no doubt, is that these flowers are very much specialised in form, so that in most species only one kind of insect can pollinate them. The shape of the flower and the position of the nectar, or whatever else is the attraction, compel the insect to enter in one particular direction, and when it does so its head touches the rostellum and gets a small patch of gluey matter on it. The threads which tie the grains together in the pollinia are joined into a tail-like process which ends in the rostellum, so that when the insect withdraws its head it pulls out the pollinia attached to it, usually in two masses. When the insect enters another flower, these pollinia-which have meanwhile become slightly depressed by their own weight--are in such a position that they are right opposite the two stigmas. On being thrust forward against these some of the grains adhere to the sticky surfaces. In this way pollination is brought about.

I have never yet satisfied myself as to how these little orchids are fertilised, though the probable insect agent in the conveyance of the pollen is a small tawny-coloured fly : nor is it easy to make out what is the attraction. There does not appear to be any nectar, but the base of the flower 
is very juicy, and probably the fly-which is gnat-like in appearance, but with a somewhat stouter body - is furnished with a sharply-pointed trunk, with which it punctures the succulent part.

In examining these flowers-and I have looked into hundreds of them-I was formerly puzzled by often finding a small red spider in each flower. Spiders, and, indeed, all things which creep and cannot fly, are quite unfitted for pollinating flowers. But a closer examination revealed this curious fact: the spiders evidently discovered that flies went into these little flowers and stayed there some time, so they went in after them and stayed too. This I found was the case by noticing that occasionally only legs and wings of flies occurred in the flowers, and on one occasion the head of a fly was found glued on to the rostellum, while the body had been demolished by a spider.

That the flowers are visited and fertilised is shown by their abundance, and by the fact that it is quite common to find the pollinia withdrawn from their anthers. It would be an interesting problem for some of our embryo botanists to take up and find out and record exactly how these little orchids are fertilised.

These pretty little plants which I have been speaking about here belong to a genus called Corysanthes, of which seven species are said to occur in New Zealand. The same gemus is represented in Australia by three species, one of which occurs along the easter'n side from Tasmania to Queensland, and has also been recorded from South Australia and Western Australia. The requisite conditions are, apparently, either a moist climate or proximity to water. Going outside of New Zealand and Australia, we only meet with Corysanthes in some of the islands of the Malay Archipelago.

Several interesting orchids are to be found in flower in November, though it is early enough for most of them. This year, although the spring was so late in coming in, growth has been so pronounced during the past month that we may consider that in many respects the season is now nearly up to normal tine. The most specialised of 
the orchids now coming into flower belong to the genus Pterostylis, so named from the winged style or column. The plants have grass-like or broadish green leaves, and the different species vary in height from 6 in. to $2 \mathrm{ft}$., but each bears only one rather large green flower, which is nearly quite closed up except in front. The peculiarity of its structure is that the lip or labellum, which hangs just at the opening in front of the flower, is sensitive at its lower end, so that when an insect enters the flower and touches the sensitive part, this lip moves back and shuts the intruder into a little box, the back and sides of which are formed by the winged column. The only mode of exit is by walking up the column; but to do this the insect has to pass the stigma, the sticky rostellum, and then the anther's, so that it emerges carrying the masses of pollen with it, to deposit them on the stigma of the next flower visited. The whole details of the structure can be read in Dar.win's " Fertilisation of Orchids."

The pretty white and red-spotted Dendrobium, one of our few epiphytic orchids, maly be found in flower towards the end of the month in a few localities down the west side of the harbour. A favourite spot for it used to be by the big rocks above Port Chalmers.

Two other orchids which begin to flower in November are chiefly interesting as illustrating degeneration. Prasophyllum colensoi is a greenish brown-streaked form which is nearly or quite self-fertile. I am not sure whether it has any fragrance or not, but it certainly belongs to a genus of which some of the Australian forms are very fragrant. It grows commonly in open grassy ground. Bnt still more abundant is a slender erect species known as Microtis porrifolia, which has one sheathing leaf on its stem, and bears small green flowers arranged in a close spike. This has become absolutely self-fertilised, and with a powerful lens it is often possible to see the pollen grains on the summit of the column putting out their tubes, so that they grow directly out of the anther on to the stigmatic surface. These plants are evidently descended from species which were originally specialised in structure and 
were probably attractive, but having in some way or other, which we cannot at present explain, become self-fertile, they have lost their attractive features and now no longer need to be visited by insects.

\section{IV.}

A question which has often occurred to me, and which is not easily answered, is as to the age of certain plants in the garden-some fruit trees for instance. It is such a curious problem, and yet one so little thought of, that it seems worth while raising it here. When we speak of the age of a plant we usually mean its age from the time of the germination of the seed, and this is so manifest a statement that it may be wondered why the question should be raised. But when I go to the nurseryman and buy a "young" apple tree, how old is it? The stock may be four or five years old, the graft may be one or two. But the graft may have been taken from a tree twenty year's old, and that from another old one, and so on. Is the "young" tree the age of the stock-namely, five years, - or is it the age of the graft-perhaps a hundred years old? There is no doubt that, as far as the fruitbearing part is concerned, the plant is as old as the seedgrown tree which furnished the original graft. This fact, which is not sufficiently realised by cultivators, no doubt helps to explain the weakness of many well-known varieties of fruit trees in relation, for instance, to their power of withstanding the attacks of certain insect and fungoid pests. I think I am right in stating, though it is only a matter of memory with me, that some years ago the wellknown Ribstone pippin apple all but died out, the grafts probably representing a tree a century or two old, and that our present grafts were the product of seed obtained by cross-fertilising a Ribstone with some other strong stock. I write this subject to correction, for I cannot now refer to the authority for the statement.

A historical instance of the same curious kind may be remembered by some of my readers hailing from Edinburgh. 
In the garden of Moray House, in the Canongate of the old city, formerly the residence of the Earls of Moray, but occupied in my boyish days (perhaps still) as the Free Church Normal School, there were two (if not more) ancient pear trees, of a fine variety known as the Longueville. It is said that the trees were brought from France in the time of Mary of Guise, wife of James V of Scotland, and mother of the famous Mary Queen of Scots-that is to say somewhere about the year 1540. At the beginning of this century, therefore, they would be some 260 years old. Even then they were bearing fruit, but sparingly, and apparently they soon ceased to do so, though they remained strong and healthy. Repeated attempts were made to perpetuate the variety by grafting them on to young stocks, and it would seem that the grafts grew and threw out abundance of foliage, but fruit they would not. No doubt this was due to the extreme age of the grafts. It is said that the Longueville pear is still known in the south of Scotland, but I do not remember ever seeing the naue in a nurseryman's catalogue.

Now what is true of trees and their grafts is equally true in almost the same way of such things as potatoes. When we plant the tubers of potatoes we are not dealing with new plants, the product of seeds. Our so-called "seed" potatoes are only short portions of thickened underground stems, and it is quite certain that by continual planting of such tubers we are perpetuating stocks which may be extremely old-perhaps a century or more. This has often seemed to me to be in part the explanation of the sudden outbreak of disease which destroyed the potato crop in Ireland in 1845. The Irish cultivators had to a large extent adopted the lazy-bed system of culture, or want of culture, forking their patches of ground in autumn, taking ont all the larger tubers, and leaving in the smaller ones to be the progenitors of the next season's crop. It is impossible to say how long this process had been going on, but it is certain that the stocks must have been very old, and they must also have been impoverished by the treatment to which they had been subjected. They were thus 
in that worn-out reduced condition in which they were very liable to be attacked by the fungus which proved so disastrous, and whose attacks they were utterly unable to resist.

Generally, in dealing with vegetables and fruits, we are apt to consider the old well-known kinds to be the best, but this is not really the case. Some of the well-known forms are no doubt still full of vigour and productiveness, and may continue so for a very long time, but the new varieties. which arise by the intercrossing of vigorous forms, are most likely to be strong with the strength of youth. Hence those new varieties which meet us so temptingly each year in the nurserymen's catalogues are almost certain to be vigorous. In no respect has this fact been better shown than in the many new potatoes which have come on the market of late years and which have been raised from seed by intercrossing.

All this applies with equal force to that numerous class of plants which is perpetuated by cuttings or slips, and it would be interesting for anyone who had special opportunities of doing so to find out, as far as possible, the age of some of our common trees and shrubs. For instance, it is probable that all the willows in New Zealand have been grown from cuttings brought ont from Europe, or, as some believe, in the case of the weeping willows, from those growing over Napoleon's tomb at St. Helena. Our purple and copper beeches and most of our poplars are similarly reproduced by cuttings. These are suggested as examples; there are no doubt many others which must be known to cultivators, and it would be worth while to examine more closely into the accuracy of my statements.

Though I have spent the greater part of this day in the garden, I have not seen nor heard a single humble bee. What has come of them of late? They have been very late about Dunedin. Many of us remember the interest with which we first learned of the appearance of humble bees here. Within one week in February 1888 
'several people in town saw them and compared notes on the subject. The following information, taken from a paper I wrote some years ago, may be new to many interested people:- “In March 1885 the Canterbury Acclimatisation Society liberated ninety-three females (queens) of Bombus terrestris in the neighbourhood of Christchurch. They appear to have established themselves at once, and increased rapidly. In January 1886 two were seen by Mr J. D. Enys at Castle Hill, on the west coast; and early in 1887 they were reported from Kaikoura in the north and Timaru in the south, while by the autumn of the same season (March 1888) they had become established in the Oamaru district. Towards the very end of the same season they had spread up the Waitati Valley, through the Lindis Pass, and were observed on the Hawea flats. In Dunedin they appeared quite suddenly in the second week of February 1888, and were almost simultaneously reported from Waihola. In November 1889 they were first recorded from the head of Lake Wakatipu, and in the beginning of 1890 were observed in the neighbourhood of Invercargill."

The subsequent wonderful increase of these insects was so rapid that beekeepers began to fear that the honey bee was going to be crowded out. But from some cause or other, which is not at present known, they appear to have diminished in numbers of late years. Darwin's explanation of the comparative abundance or scarcity of humble bees in England is familiar to many, but as it may not be known to some I may with advantage reproduce it here. He is discussing the question of the fertilisation of the red or meadow clover (Trifolium pratense), and he asserts, on the authority of a Colonel Newman, that it depends on the number of cats in the district. This seems a most absurd statement at first sight, but it is quite correct, as the following explanation will show:- Red clover is only visited and fertilised by humble bees, but "the number of humble bees in any district depends in a great measure on the number of field-mice, which destroy their combs and nests, and the 
number of mice is largely dependent on the number of cats. Hence," adds Darwin, "it is quite credible that the presence of a feline animal in large numbers in a district might determine, through the intervention first of mice and then of bees, the frequency of certain flowers in that district."

Now, I am not aware of any enemies that the humble bees have here. There are certainly lots of mice and rats in the open (not field mice, however), but there is no evidence whatever that they touch the bees' nests.

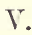

In sauntering about the garden at this time of the year I notice in the ground occupied by fruit trees (which is not as free from weeds as it should be) that when the sun is shining brightly one of the small weeds becomes quite showy with pretty blue flowers. The blossoms are not only very ephemeral-lasting indeed but a short part of each day,--but they do not expand except during sumshine. In this they resemble such wellknown flowers as the Star of Bethlehem (which is called in French by a name signifying Lady Eleven O'clock), and Pimpernel, which from its habit of closing its corolla as soon as the sun is overcast is sometimes kuown as the Poor Man's Weather Glass.

The little blue-flowered weed is an European Veronica or Speedwell (scientifically named $V$. Buxbaumii), which I first remember in this part of the world as appearing at Port Chalmers about fifteen years ago. It had apparently sprung up where some chaff beds from an immigrant ship had been burned. I have since met with it frequently in gardens in the Taieri and elsewhere. The little flower, which is less than half an inch across, has its corolla so deeply divided as to appear to consist of four petals, of which the front or lower one is smaller and paler coloured than the others. These petals are of a fine blue colour, striped with dark blue lines, which converge towards the nearly white centre of the flower. 
Such lines of colour converging towards that portion of the flower where the nectar is secreted are very conmon in insect-visited flowers, and have been called honeyguides. They no doubt serve to direct insects to the little recesses in which the sweets they look for lie hidden, for it must be renembered that such insects as bees and wasps are guided more by sight than any other sense. Two white filaments stand up from the base of the corolla, each ending in a dark-coloured anther, from which a little pale whitish pollen is discharged. Projecting away in front of them stands the single style, with its minute brush-like stigma, but this seems gradually to stand up straighter, and so come nearer the anther cells. There seems no reason why the pollen should not find its way directly on to its own stigma, supposing some insect did not visit the flower and scatter other pollen on it. And if it does not do so while the flower stands open, it is almost certain to be left on it when the corolla drops, for in doing so it pulls the two stamens off with it, and these very frequently smudge the stigma as they fall.

In the flower I am looking at now is a small active insect - a Thrips, - but neither its smallness nor its activity will enable it to reach the nectar, of which apparently only a very minute quantity is found at or near the base of the corolla. For inmediately above the base numerous rigid hairs protrude towards the centre of the flower, forming a network easily enough thrust aside or pierced by the trunk of a bee, but quite fir'm enough to exclude the small insects which would only rob the flower without bringing about cross-fertilisation.

Even while looking at this flower a breath of wind shook it and the little blossom rolled off, the second which has fallen to-day from the same branch, and it is not yet noon. The very short-lived character of this flower, which it shares with many others equally brilliantly coloured, is partly the price it pays for being so showy; but it is no doubt also a secondary character which it has developed along with its faculty of becoming self-fertilised. For it is 
curious how long certain highly-specialised flowers will remain open if fertilisation is prevented. I have kept an orchid, (a species of Cypripedium), in a somewhat shady room where no suitable insects were to be found, for over seven weeks, and at last had to send it back to the greenhouse, not because its blossoms had faded at all, but becunse they had become dusty. But this little speedwell gets no time to be dusty : if the right visitors do not come along when it holds up its pretty petals to be kissed, its reproductive process is performed by its own pollen, and the corolla drops, its beaut $y$ having failed to be of service to it.

There are two other introduced Veronicas common in this neighbourhood, and one of them-V. arvensis-is, I regret to say, very common in my garden. It is nearly as troublesome a weed as the little bitter-cress, for it has developed the faculty of self-fertilisation to such a complete extent that it usually ripens its seed capsule without opening its flowers at all. When it does do so, and this only happens on sunny days, it is seen to have almost the same structure as the larger species, only its corolla is very minute, very deep blue, and extremely transitory. It appears to be there as if to say "I want to show you that I am a Veronica, but my beautifnl colours are not needed now, only if I did not show them occasionally you might think I had not got them to show, which, of course, is not the case."

The third species-Veronica serpyllifolia - is common in many damp open parts of the Town Belt and elsewhere. Its flowers are intermediate in size between the other two, are white or lilac in colour, lout with the same blue stripes, and are not so ephemeral as V. Buxbaumii. This lilac tint is a more generalised and more primitive colour than the blue, and many blue flowers appear to have developed from white through lilac to blue, which is the most specialised of all. A familiar example is the common forget-me-not.

In all three Veronicas the ancestral forms must at one time have been thus highly specialised in colour and markings that they might be visited by insects, and some of the better known European forms, like Germander Speedwell 
V. Chamredrys) and Brooklime (V. Beccabunga) still retain their ligh specialisation. It was probably their beauty and their open face which suggested to Tournefort their generic name.

Medireval legend tells how, when the Saviour was toiling along to the hill of Crucifixion, bearing His cross, a compassionate woman whose house He was passing, pitying the worll sufferer. wiped His face with a napkin, and how on the cloth was found the impress of the divine features. She treasured the sacred representation, the Vera Eikon or true image, as it was termed in the hybrid Latin-Greek of the early (hristian ages. Then by a common conceit she came to be known by an inversion of these words as Veronica, and by this name she was canonised. So the botanist, seeing the clear blue colour of the Speedwell blossom upturned to the sky, and, as it were, reflecting the azure vault, called the little flower the true image, the Veronica.

Coming back for a moment from the romance of science to its facts, In what part of the world did Veronicas originate? Such a question may arise in the mind when we consider what is the present distribution of the plants of this genus. But we cannot answer it. They occur in the North Temperate Zone always as snall herbs with usually alternate leaves and blue or bluish flowers; they are apparently found nowhere within the tropics, but they reappear in South America, in Australia, but especially in New Zealand, where they constitute one of the most characteristic plant gromps we have. But in these islands they occur most commonly as shrubs, and have opposite usually uncut leaves, and flowers which are white, pink, or lilac, but rarely blue in colour. There are a few exceptions to the preceding general character, and one species occasionally foumd in the North Island is the same as a common Enropean plant.

The genits must have been widely spread at one time, perhaps over a submerged Antarctic continent, and it must be an ancient genus, for the species present a most remarkable diversity of structure. One of them. Veronica elliptica, which is a very common and familiar shrub along the sea- 
coast, is found in equal abundance in Southern Cbili, 'Tierra del Fuego, and the Falkland Islands, and this may represent one of the primitive forms which has survived through long ages.

The smallest species in New Zealand- $V$. canescens - is a minute creeping plant of a grey rather than a green colour, which grows so close to the soil, which it resembles in colour, that it is almost invisible until its little blue flowers open out. These only expand in strong sunlight, and are as evanescent as those of the imported speedwell. Between this pigmy, whose leaves do not exceed a tenth of an inch in length, and some of the large shrubby forms, with leaves from four to six inches long and fine racemes of white, bluish, or purple flowers, a great variety of plants is found. Hooker catalogued forty species as occurring in New Zealand; Armstrong (of Christchurch) recognised seventy; while Mr Cheeseman, of Auckland, who is the author of the recently published "Manual of the New Zealand Flora," describes eighty-four. But the mere occurrence of such a number and such variety points to a long ancestry, and further shows that they must have been subjected to very varying conditions to attain their present characters. 


\section{Chapter II.-December.}

\section{I.}

YOW that the Clematis flowers have passed, the native 1 bush has not a single conspicuous blossom left. Beautiful as are the shades of green which characterise the foliage, yet it is true that as compared with the vivid colours of a woodland scene in the old country our bush has a somewhat sombre aspect. The most sombre hues are those of the Fuchsia and the large-leaved Panax (sometimes erroneously called New Zealand gum tree), but there is a wonderful diversity of colour and shade in the banks and masses of foliage which ncet the eye in a bit of the native forest or scrub. There is nothing so restful to the eye as the greenness of grass and of young foliage, and though most of our native trees and bushes lack the vivid verdure of a meadow in spring time, yet they have a quiet beauty of tint of their own which is very charming. Looking over a bit of greenery filling one of the dells which cross this romantic Town Belt of Dunedin, I can see about a dozen shades of colour, varying from the bright green of the young broadleaf* and Muhleubeckir (what a name for a graceful clinging climbing plant!) to the olive and russet greens and browns of the red mapaut and the pepper tree, + and the dark hues of the Fuchsias, all blending harmoniously into one another. Among the foliage there are flower's in abundance, though mostly so small and so unassuming in appearance as to escape notice. Still there are numerous and interesting things to be seen among these unobtrusive flowers. The common Fuchsia is a good example. Its branches are just now often crowded with flowers, though their season is nearly past. These are of a green or greenishpurple colour, and in general form resemble many of the kinds frequently grown in the garden or greenhouse,

\section{* Griselinia littoralis. + Myrsine Urillei. $\quad$ +1)rimys colorata.}


though the latter are usually more slender, and also more highly coloured.

Let us look at these flowers. They are always placed on the lower side of the branch; whatever their position may be primarily, their stalks curve in such a manner as to bring

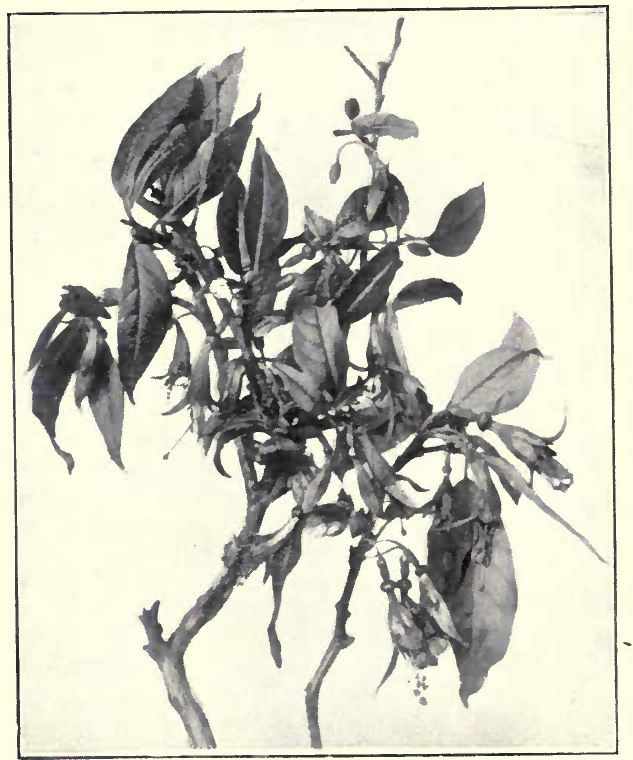

Fuchsia excorticata.

them to the under-side. In the cultivated species, which are all of South American origin, this pendulous character. is usually more pronounced, and in both cases it is associated with the mode in which the flowers are cross-fertilised by honey birds. In most flowers the calyx is a protective 
organ, the corolla being the coloured and attractive portion, but in Fuchsias the calyx has become chiefly attractive, and the petals tend to become reduced in size correspondingly. In the South American species both whorls are brightly but usually differently coloured, and it is in part the contrast between them which causes the flowers to be so conspicuously bright. But in our common bush form the petals are reduced to little dark purple scales which stand between the divisions of the calyx, while in the small creeping Fuchsia procumbens, from the Great Barrier Island-commonly cultivated here as a pot plant on account of its inability to stand the southern winterthe petals have disappeared altogether. Protruding from the mouth of the calyx are eight stamens, the anthers of which all open at the same time and display their little masses of bright blue pollen. It may be noted here that blue is not a common colour in pollen; it acts in this instance as an additional attraction to a flower which has evidently lost brilliancy of hue in other parts. Hanging out from the centre of the flower is a long reddish style, ending in a rather large greenish or yellowish stigma, which is often seen to be smeared with blue pollen. At first sight the flower seems to be fitted for self-fertilisation, as if the pollen could drop readily on to its own stigma, yet a little examination shows that this is not the case. In the first place, flowers do not produce nectar for nothing - they are constructed on the Bismarckian principle "do ut des"and if the dilated nectaries of these Fuchsias contain much sweet fluid, it is as a bait to the korimakos and tuis, * which are needed to fertilise them. Then the pollen does not drop out of the anther cells, and you cannot make it do so by shaking. If a little of it be mounted in a drop of oil and examined under the microscope, it will be seen that all the minute grains are tied together by fine threads so that they do not fall away from each other. It is a very easy thing to watch korimakos at work on the flowers, for if the watcher keeps quite still and has a little patience the birds

*The Korimako or Bell Bird (Anthornis melanura). The Tui or Parson Bird (Prosthemadera Nove Zealandie). 
will show plenty of confidence and will reward his watch. How actively the little lithe creatures move among the branches, bending and twisting their graceful bodies and necks under the flowers, into each of which the long brushtipped tongue is thrust! While so engaged the feathers at the base of the bill and on the front of the head become smeared with blue patches of pollen, which is thus conveyed to the stigmas of other flowers. Were the korimako a quiet and rather sedentary bird, such visitations would only bring about fertilisation of flowers by others on the same tree, but so restless is it and so perpetually on the move that it flits about from tree to tree as if it revelled in the abundance of the feast provided for it.

There is a second form of Fuchsia in the bush, not so common as the larger one but still abundant enough, which is characterised by its smaller leaves and much smaller paler-coloured flowers. What marks it ont most clearly from its commoner relative is that the stamens are not only very much reduced in size, but that their anthers contain no pollen. Thus, while the flowers of the larger form are probably incapable of self-fertilisation, though possessing both the reproductive whorls fully developed, this smaller kind is also hermaphrodite in structure, but is strictly female in function, being absolutely dependent on pollen from the larger form for fertilisation of its ovules. The stigmas are often to be seen smudged with blue pollen, and the plants bear abundance of berries, so that the flowers must be freely visiter.

Both these forms belong to the same species, $F$. excorticata-so called from its habit of casting off its light-brown papery bark - and it is one of the curious problems still awaiting solution at the liands of botanists why so many flowers in this country are sexually imperfect. Sometimes a third form is met with in which the flowers are intermediate in structure between the other two.

What a curious problem is shadowed forth by the distribution of the Fuchsias. The genus occurs only in the South American region (where it ranges along the Andes from Mexico to the Straits of Magellan) and in New 
Zealand. Whichever region is its headquarters or starting point, the question arises, How did it spread to the other? Land connection say some, ealmly ignoring the thousands of miles of ahyssal seas which separate the two areas. The seeds could not be carried by the wind, for they are enclosed in a succulent berry. But they could be and are carried in the crops and stomachs of birds, and in this way might be borne a thousand miles or more by chance. For it is not an uncommon thing in the Auckland peninsula, after periods of westerly gales, to hear of Australian birds which have strayed there, and for one that is seen or shot there must be many which arrive and probably get killed by gulls and other coast birds or succumb to the severe knocking about they have got. In some such way it might be possible to account for succulent-fruited plants being spread across considerable areas of sea or from island to island. But unless there were, during past epochs, intervening islands-not necessarily, of course, in a straight line-it is difficult to account for the occurrence of Fuchsias in two so widely separated regions and nowhere else on the surface of the globe. The evidence at present available points to a former land connection across the antarctic, but it is still problematical, and we must wait for further light on the question before coming to a decision.

I have spoken of the sombre hnes of the Fuchsia, but what a pretty sight it is on a bright breezy day to see the play of colom as the wind turns up the whitish under-sides of the leaves. Thongh thin in texture, and exposing a large surface to the action of the sun and wind, these leaves are remarkably well protected against extremes of heat and cold. Their upper surface has no or very few apertures. while the green pigment which so freely absorbs the sum's light and heat is densely packed in the cells just underneath it. The lower surface, on the other hand, is perforated by very numerous stomata or breathing pores, and the cells immediately under the epidermis contain only air, and hence act as a non-conducting layer as far as heat is concerned. From rough measurements I calculate that there are about 350,000 stomata on every square inch of the 
under surface of a Fuchsia leaf. What an amount of water a large tree of this species must evaporate in a dry summer day!

In this southern end of New Zealand, and on the mountain slopes, the native Fuchsias are deciduous. Were it otherwise they would be stripped of leaves and branches during winter, for the latter are brittle and easily broken, and are also frequently spread out at rather low angles, while the abundant leafage would cause them to catch and retain snow readily. Then, as a rule, the snow in this temperate region is large-flaked, soft, and not much removed from the melting point. It is therefore particularly liable to cling to foliage, and is thus far more destructive than crisp dry small-crystalled snow would be. The Fuchsia shares the deciduous habit with only a few other New Zealand trees and shrubs, such as the mountain ribbonwood* and, to a partial extent, the mako-mako.t The absence of deciduous-leaved trees in these islands is an argument against any recent glacial epoch in these southern regions.

\section{II.}

The magnificent floral display of the broom and the gorse during the last month, the great promise of flowers on the elderberry, and the exuberant huxuriance of cocksfoot and other introduced grasses in the recent moist mild weather, show what a remarkable hold these immigrants have taken of their new home. I was on the lookout for Tutu the other morning, and noticed how scarce it is becoming in localities where only a few years ago it was one of the most abundant of the native shrubs. Some native plants are more than holding their own in the 'Town Belt, such as the fuchsia, wild bramble or lawyer, and the common climber Nuhlenbeckiu. This is in part due to the fact that they have succulent fruits which are eaten by blackbirds and thrushes, and so have their seeds distributed in the same way as happens with the elder-

$$
\text { * Gaya (Plagianthus) Lyalli. +Aristotelia racemosa. }
$$


berries, and partly - at least as regards the two last namedon account of their vigorous growth as climbers, for they scramble over other plants and seek to monopolise their light. The tutn also has succulent and attractive fruit which we might expect to be scattered in the same way as the others named, yet it is not increasing. Perhaps the fact of its growing near the edge of the bush, where futile attempts are made from time to time to eradicate gorse and broom by burning, may account for its disappearance from many localities, for it is a somewhat easily destroyed plant.

Twenty year's ago there were various other plants besides Tutu to be found in our Town Belt which are very difficult to find now owing to the spread of the introduced plants. The common little orchid Corysanthes and the curious grayish-green Gastrodia have disappeared from many of their old haunts; the curious Moonwort (Botrychium ternatum) and the little Adder's Tongue Fern (Ophioglossum) are things of the past; while the liliaceous Dianella, with its little nodding flowers followed in autumn by dark blue berries, is among the missing. These aud nuany others are not rare plants, for they can be met with in abundance by going a little further afield, but they have disappeared from spots in the Town Belt where formerly they could always be found; they have been crowded ont of existence by stronger and more aggressive species.

The Tutu (Coriaria) is a plant with many peculiar characters and points of interest. It is evidently of great antiquity, as evidenced by its own distribution and that of its genus. Three species of Coriaria are recognised as occurring in New Zealand, and all of them occur in the neighbourhood of Dunedin. The common perennial shrubby form-C. ruscifolia-grows near the edge of the bush right down to the sea level; the other two-C. Ihymifolia (the thyme-leaved form) and $C$. angustissima are only found at or above 2000 feet. They are much smaller than the common shrubby species, more slender and delicate in their leafage, and they die down to the ground each autumn. 
These two can be found on the slopes of Swampy Hill, at the head of Nicholl's, Morrison's, and other creeks, which come down into the Leith. No doubt, also, they occur in plenty of other similar localities in the adjacent hills, for they are common throughout sub-alpine districts in this

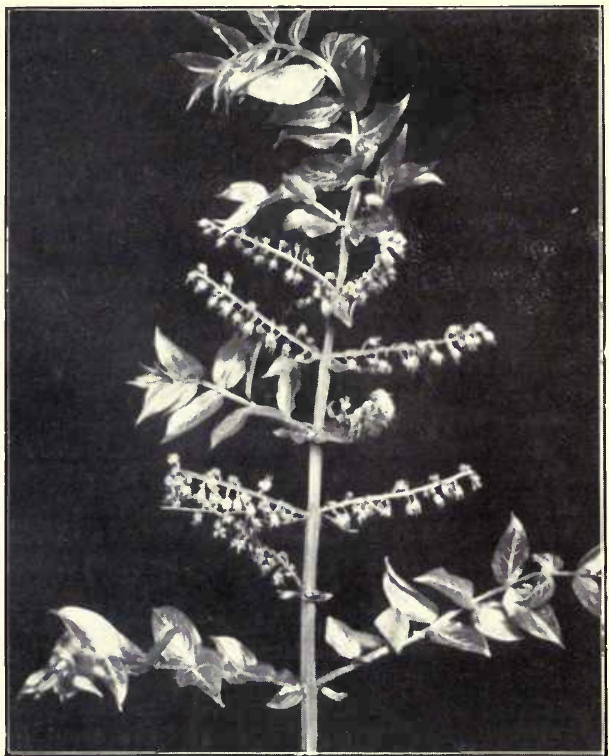

Tutu (Coriaria mescifolia).

island. How far these three plants are distinet species, or only varieties of one very variable species, is largely a matter of individual opinion. I could easily pick out of my herbarimm three specimens so different from each other as to leave no doubt as to their specific distinctness. On 
the other hand, were I to lay out on a table a series of specimens collected at various localities and elevations, from the shores of Otago Harbour to an elevation of 6000 feet or 7000 feet on one of the western mountains, it would puzzle a systematist to say to what species some of the intermediate forms belonged. What is perhaps of more interest is this, that Coriaria ruscifolia is as common in Chili as in New Zealand, while $C$. thymifolia ranges from Peru to Mexico along the main chain of the Andes at elevations of from 4000 feet to 12,000 feet. This recalls to some extent the distribution of the Fuchsias, except that the New Zealand species of the latter are quite different from the South American. Both of our species of tutu occur in the Kermadec Islands, which lie pretty far to the north of the New Zealand group of islands. These facts point to the antiquity of the species, while the distribution of the genus bears ont the same idea still more. Species of Coriaria occur in Southern Europe, Japan, China, and the Himalayas; indeed Linnæus gave the generic name to the plant, because the roots of the European species (C. myrtifolia) have long been used in Southern Russia and elsewhere for tanning leather.* Now if one might hazard an interesting speculation, I would suggest that in a former geological age Coriaria was spread over the extreme north of the northern hemisphere at a time when the climate of Spitzbergen was that of a temperate region. When the great ice-caps of the last or some preceding glacial epoch began to settle on the North Pole, driving the vegetation southwards, Coriaria had to retreat along with other plants. It appears to have followed two lines of retreat, one down to Sonthern Europe, and another through the Alaskan or Behring Sea region, this latter probably dividing into two branches, a western line passing down by Japan and China to the Himalayas, and an eastern down the mountain chains of America, from whence it spread across the Pacific to New Zealand by a now submerged chain of communications. Such speculations are

* Latin, Corium, leather. 
more than merely interesting, they frequently lead to suggestions from which come practical discoveries. As far as I know no fossil remains of tutu have ever been recognised, and the only parts likely to leave any identifiable fossils would be the leaves and stems; but it seems to me quite possible (I will not say probable) that such clues to its past history may yet be found. A statement of an analogous case will show that my supposition is not unfounded. Everyone is familiar nowadays with the coniferous tree patriotically named Wellingtonia gigantea, the Mammoth Tree of California. Its botanical name is Sequoia. Two species of Sequoia are found in the Rockies - the large, S. gigantea, which is nearly extinct in its native habitats, and the Californian redwood, $C$. sempervirens. Besides this, a fossil species is found in Japan, another in the coal beds of Spitzbergen, and another in the Miocene rocks of Switzerland. This distribution, representing probably an older type than Coriaria, is not very dissimilar, and the usually received geological explanation is that the genus was driven south by former extensions of Arctic ice, and that it followed the three lines of migration indicated.

There is another feature about Coriaria which shows the antiquity of the form, and it is that it has no living allies. Botanists don't know where to place it, or with what other groups of plants it should be classified.

The flowers of tutu are worth looking at just now. They are quite out of the ordinary in their development. When they first open they often appear to be rusty or brownish red, this tint being due to the colour of the backs of the undeveloped anthers. They have each five small green sepals, between which appear the points of five smaller and paler petals, then ten unripe anthers, and in the centre five or more red styles, which are stigmatiferous all over-that is, covered with little sticky protuberances, so that pollen grains will adhere to them. These styles are the first and most conspicuous part of the flower to mature, and they remain protruded for a week or more, so as to catch any pollen which may be 
floating about in their neighbourhood. I have noticed that while the upper flowers on a cluster-really the lower ones, however, as the racemes hang down-nearly always have five styles, those nearer the base of the cluster have seven, eight, or ten. I don't know whether this is a common fact.

After the styles have shrivelled, the anthers mature, their stalks slightly elongating. As they then hang loose to the wind, the slightest breath of air stirs their pendent clusters, and scatters out the dry dusty pollen in little clouds. This is a curious device to prevent selfand bring about cross-fertilisation; and, as is the case in all such wind-fertilised flowers, the number of pollen grains which go to waste and fail to reach a stiguna must be enormous. After fertilisation the petals begin to grow, and become full of purple juice, eventually forming the so-called berries, inside of which are the small hard dry fruits which are commonly known as seeds.

Tutu is well known to be one of the few poisonous plants which occur in New Zealand. The poison is most abundant in the seeds, but it is also found in the stems and foliage. The drovers and early settler's of the colony were very familiar with the effects of this plant on cattle. Animals taken quietly on to tutu-covered ground and allowed to feed there got into fine condition on it, even when they ate it freely. But if a mob of cattle which had been driven all day were brought to camp on such ground, many of them used to go mad during the night, and the drivers had a bad time of it, often losing several of their beasts.

\section{III.}

Many of the seaside plants are in flower now. A typical and very common one, which grows right down on the sand near the beach, is a very pretty creeping Convolvulus ( $C$. soldanella), with bright green delicatelyveined kidney-shaped leaves and rose-red flowers, often ornamented with purplish stripes. Like many littoral 
plants it has a great range, being found on the coasts both of temperate and tropical Australia and right away to Emrope. As a boy I can recall its occurrence on the shores of the Firth of Forth. Its seeds are probably capable of floating for a long time in sea-water withont being injured-indeed, the plant will not, as far as my experience goes, grow away from the neighbourhood of the sea and of salt water. I have never succeeded in germinating the seed in ordinary soil, nor have plants brought from the beach and placed in the garden border ever survived. It is an example of a plant very greatly specialised for the particular habitat in which it occurs. Another plant which affects brackish lagoons and damp spots is Mimulus repens, a low-growing small herb, whose pretty purple flowers, with their yellow throat, make it a conspicuous object. The most curious feature noticeable about all species of Mimulus (the common yellow musk is a good example) is the possession of a two-lobed stigma, of which the lower lobe or plate is sensitive. This is a feature they share with several other' plants belonging to the same natural order (Scrophularinea). If you look into a flower of musk you will see the little stigma like a small whitish disc at the back of the flower facing you, and probably wide open. Touch the lower plate or lobe with the point of a blade of grass, and it will almost immediately close up. This is one of the many devices which exist in brightlycolonred flowers to bring about cross- and to prevent self-fertilisation. If an insect thrusts its head into the flower and touches this stigmatic plate it at once closes up, but in the course of twenty minutes or so it opens ont again if no pollen has been placed on it. In withdrawing from the flower the insect brushes out a quantity of pollen from the anthers, but the stigma being closed none of this can get on to their inner surface. But the next flower which is visited receives some of the pollen on to the lower lobe of the stigma, which then closes up and does not open again. The flower being thus pollinated and fertilised soon withers, 
the work of the corolla being accomplished. Our purple seaside species shows this character very markedly. This plant is equally common on the shores of South-eastern Australia and of Tasminila.

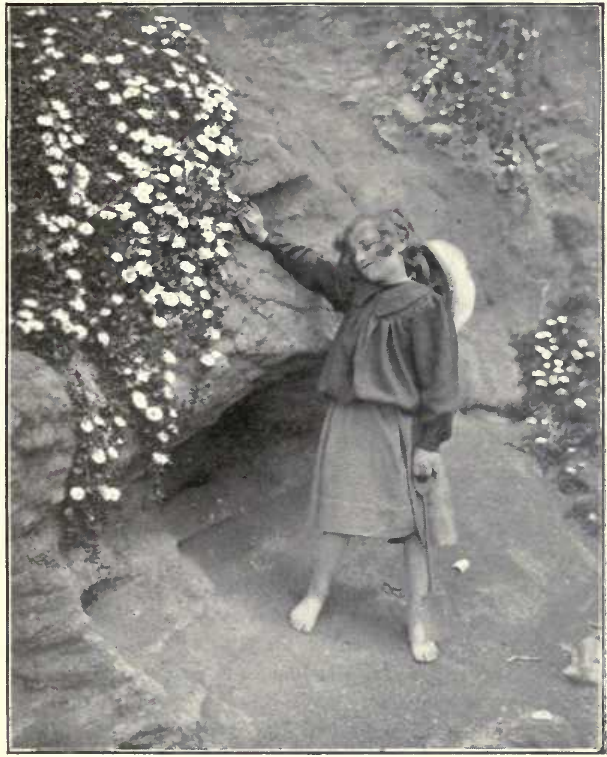

Mesembryanthemum australe.

Another widely-spread littoral plant is the succulent Mesembryanthemum austrule, called Pigs-face in Australia, but often better known as the Fig-marigold. Linnæus must have been somewhat hard put to it when devising his system of binomial nomenclature to invent names for all the plants which he described. This genus he named 
from two Greek words meaning " midday flower." The triangular leaves, full of a saline sap, are peculiar, and the pink flowers resemble those of a small cactus in the great number of petals which form the corolla. Our species is also found in Australia, where, according to some authorities, it is stated that the leaves are eaten pickled. But 1 never came across any person who had tried them. The fact is that in our food, as in so many other things, civilised men tend to become cosmopolitan, and having got accustomed to certain articles of diet we use them into whatever part of the world we go. In earlier days, before the advent of the rapid methods of transit which now prevail, people often utilised local somrces of food supply which are now discarded and forgotten. The local species of Vesembryanthemum is apparently the sane as a Cape species, and it is in South Africa that the genus is chiefly developed. One of the Cape species (. $\%$. crystallinum) is often cultivated in gardens under the name of the Ice Plant.

Allied to Mesembryanthemum is another succulent-leaved plant, with dark green leaves which glisten more or less with small transparent papillæe and small yellowish flowers, and which has long been cultivated in Europe under the name of New Zealand Spinach. It is technically named Tetrogonia exponsa, and, like so many seaside plants, is widely spread, ranging to Anstralia on one side, South America on the other, and as far north as Japan.

The adaptability of plants to various habitats is well illustrated by the examples cited, but the possibility of flowering plants actually invading the waters of the sea and acquiring a submarine habit seems almost incredible. Yet such is the case with more than one group, and the best local example I can quote is Zostera, the common Sea-wrack. 'This is the bright green grass-like plant which is so abundant on the banks in our harbour, and which is equally common in many of the lagoons and estuaries which occur along the coast. It is a true-flowering plant, allied to the pond weeds which grow in fresh-water ditches and ponds. If one examines the leaves at this time of year 
the base is often seen to be somewhat swollen, and on opening this part there is observed an elongated watertight case, made by the folded margins of the leaf, in which the flowers ire arranged in two rows. These flowers are of two kinds, the male consisting each of a single one-celled anther, and the female of an ovary with one pendulous ovule. It is interesting to speculate on the profound changes which have caused a flower with six perianth leaves, six stamens, and a three-celled ovary, as there is good reason to believe the ancestral form possessed, to become modified into this retrograded and very much altered submarine plant.

\section{IV.}

It is only a step from the dry sand above high-water mark to the sea itself, where new sources of interest continually await ns. The sea at all seasons of the year, and in nearly all weathers, yields an abundant harvest to the naturalist. At this time of the year periodical migrations of fish take place, as may be seen by the great abundance of red cod* in the harbour, and barracoutat are frequently plentiful on the coast. There can often be seen in the sea in calm weather large bands of gelatinous-looking substance which these fish apparently eat, and which has therefore been termed "barraconta feed" by the fisliermen. I believe that when this substance is met with in abundance on or near the surface, the fishermen at once look out for barraconta, and begin to watch for them with great keenness. These bands of gelatinous material consist of immense numbers of large transparent salpæ floating in close proximity to one another. Each Salpa has a glass-like case or test about an inch long, crossed by delicate bands of muscular fibre, which give it a more or less transverselystriped appearance when the animal has been placed in spirit. Whole tests or fragments of them are frequently met witl washed up on the beaches. Aloug with these, the cases of another allied animal (probably a Doliolum) are very common. Each case is like a wide glass barrel,

* Red Cod (Physiculus bacchus). + Barracouta (Thy'rsites atun). 
open at both ends. Usually each of these cases contains a transparent glass-like shrimp (Phronima), which makes use of the empty shell as a convenient dwelling place.

For anyone who is merely interested in looking casually at this class of seaside objects, even without the trouble of studying them, there is no better way than to go out with a stout tumbler in the hand. Whenever a specimen is met with on the beach or in a rock pool pop it into a tumblerful of clear sea water. What may seem a limp sand-encrusted bit of dead matter lying on the beach often becomes a beatiful moving organism when restored to its native element. Very few people but those who have taken the trouble to look at them know the beauty of many of these seaside organisms. They cammot be appreciated by holding them in the hand for examination; but see them surounded by limpid water, in which they maty float freely. and their. organs expand, and they become things of beanty. A seaslug is not particularly attractive when rolled up into a shapeless mass, but place it in a transparent vessel of clear water, where it opens ont its phume-like gills. and it is transformed into a marvellously beautiful structure. Again, a green worm creeping among the stones or through the seaweed is not the sort of thing that fascinates the average individual, but looked at through the safe medium of a layer of glass, its movements in the water are both interesting and beautiful. Rock pools often contain shrimps, hermit crabs, various kinds of small fish, numerous shellfish, barmacles, serpula, and other kinds of small fr.y : and if you want to know what they are really like imprison them for a short time in a glass vessel for examination. 'This note will have been worth writing if it induces any visitor to the seaside to try the experiment I have suggested: to many it will open a new field, and help to dissipate the ennui from which even holiday-makers are al)t to suffer. 


\section{Chapter III.-January.}

I.

$\mathrm{T}$ is wonderful what an amount of interest can be extracted out of an acre of garden ground by merely watching the animal life which occurs in it. The regular inhabitants are legion, and the visitors are legion too. Certainly many of the creatures we now find have been recently introduced into these islands, but whether indigenous or imported there they are in abundance. Bird life is very abundant, in spite of the constant sport indulged in by the harmless necessary cat. "Tom" is always on the alert and stalks his gane with great solemnity, but he seldom makes a capture, though he succeeds in frightening away many a desirable guest. The excited maternal cries of a thrush or blackhird tell of his continual pursuit of the recently-fledged young, but his sporting tendencies do not save the small fruit, which serve to attract and feed a small army of these birds. What diggers thrushes and blackbirds are! They burrow holes into the sides of the hotbeds to find the small red worms which congregate there in numbers, and if any manure be left imperfectly dug into the borders, they make a hole in the ground like the scratching of a young rabbit. What is the price we pay for having these birds in the garden?-A heary toll on the currants, gooseberries, raspberries, and pears; later on in the season the stripping of the hollies and the rowan trees of their pretty fruit : the invasion of the native bush by a dense undergrowth of elder berries; and total inability to grow cherries or strawberries except under nets. And in return, not only their song, which though silent or nearly so now, is a charm for great part of the year - but wonderful immunity from slugs and many an insect pest.

Starlings and sparrows though abundant enough all round us do not find good building room on my slate roof; but the latter birds do more than their due share of mischief 
- digging up the early peas as they spring above the ground, and disbudding the gooseberries as they put out their tender shoots in early spring. No doubt they also do good, but it is not so clear in what direction. I have frequently noticed in my walks through the Town Belt how the sparrows hawk for moths on the wing, and how often they light down on the path to strip a moth or beetle of its wings.

I was greatly interested this last winter to notice that the starlings were feeding on the berries of the cabbage tree.* These are white and conspicnous little fruit produced in immense clusters, but the individual berries do not seem to be very attractive, for the fleshy portion is very thin and rather dry. Apparently insect food was rare, for starlings are not as a rule fruit-eating birds. But I remember that Rabelais in his Gargantua speaks of their having to be kept off the vines when the grapes were ripening.

A thick holly hedge surrounding the garden makes splendid shelter for that pretty tinid little brown bird the hedge sparrow, which is one of the commonest of our bird friends, and which, thongh such a quiet little creature, has a low sweet piping song. Everyone surely is familiar with the pretty sky-blue eggs, of which four or five are laid in the mossy nest. The colour of these eggs and of those of the thrush seems at first sight calculated to attract attention, but, as Wallace has pointed out, "it is very doubtful whether they are really so conspicuous when seen at a little distance among their usual surroundings. For the nests are either in evergreens or are surrounded by the delicate green tints of our early spring regetation, and may thus harmonise very well with the colours round them." One often sees a beautifully marked moth or butterfly which seems a very conspicuous object in a cabinet, lut if we see it flying and watch it as it lights on some leaf or stem we often find it very difficult to detect it when at rest among similarly-coloured objects. So the eggs of a hedge sparrow are conspicuous enough when 
placed in the hand, but when seen in the ever-changing lights and shadows of the foliage in which the nest is built they are not at all readily seen. The hedge sparrow is a valuable bird in the garden, picking up insects and small seeds, and he has no evil police record against hinı, as his neighbour and namesake the conmon house sparrow has. Another common and useful bird in the garden is the beautiful little goldfinch. This summer they have not been so common as usual, and have built no nests in the garden. But last winter they were most abundant, lighting in small flocks on the seeding heads of the cornflowers, of which there were great beds. These little birds are particularly fond of the seeds of composite plants, a fact which has gained for them their commonest European name of thistlefinch.

Less common visitor's are the little wax-eyes, familiarly known as twinkies, and sometimes called blight birds, * from their habit of picking off minute insects from the tree stems. This last summer they discovered that fruit was good to eat, and they did their best to destroy a very fine crop of pears and plums.

Occasionally we have visits from tomtits (not the British bird of that name, but a charming little black-eyed pert beanty), from fan-tailed flycatchers, ${ }_{+}^{\ddagger}$ both the pied and the black forms, and from the small grey warblers. $\$$ These native birds are over confident, and consequently fall too easy a prey to cats. The fantails are especially charming little birds, and get so familiar that they will flit about a window till it is opened, and then, boldly entering the room, will pick off the small flies and spiders which are to be found at this warm season of the year. Usually these native birds retire to the denser parts of the bush at the breeding season, but a pair of grey warblers have for some years built their nest in a tall deutzia a few yards from my study windows, and here they rear their young successfully year after year,

* Zosterops carulescens. +Petroica macrocephala. †Rhipidura flabellifera and $R$. fuliginosa. \$Gerygone faariventris. 
A Japanese quince (Cydonia japonica) growing under the window, and which at this season is covered with its clusters of scarlet blossoms, proves very attractive to korimakos, and occasionally to tuis. The former is one of the few native birds which has not becone raxe in this neighbourhood. The profusion of flowers in the gardens proves attractive to it, and it is apparently too active and too fond of the high branches of shrubs and small trees to suffer from the cats which abound. Its song, consisting of a succession of liquid bell-like notes, seems to gurgle out of its throat. The bird itself is rather smaller and of more slender build than a thrush, of a bright olive-green colour on the body, with darker-almost blackish-tints on the wings and tail, and a buish hue about the sides of the hear. It hops restlessly from branch to branch the very embodiment of activity, twisting itself in and out among the bright blossoms, and momentarily dipping its tongue into each flower. Sometimes it lights on the ground to reach a bunch of blossoms hanging low down on the plant, but its movements there seemed constrained and stiff, whereas on the branches its actions are sinuous and graceful.

The tui is a handsome glossy black bird whose feathers shine with iridescent hues in the changing light; its tufts of white feathers at the sides of the neck suggesting a parson's bands. Like the korinako it is a honey-bird, with somewhat similar bell-like notes, though it can and does mimic many other songsters. It is a bold dashing bird and can hold its own against all the introduced species.

Another bird which occasionally visits the garden is the long-tailed cuckoo.* Usually its screech is to be heard in the neighbourhoor of Dumedin about the second week of November, but this year one made its appearance in the wooded gully below my house in the middle of October. By the second or third week of February these birds usually take their departure for the sumny isles of the South Pacific, where they pass the winter season, returning to New Zealand to breed. 
Only once have I seen a shining cuckoo* in the garden, and then it was a belated specimen. This species is seldom seen in the immediate neighbourhood of Dunedin, though it occurs in the district, and its advent caused quite a flutter of excitement in the family. It was on a fine day in April, one of these soft mild days that often gives a sort of Indian summer feeling to our late autumn. We were sitting at lunch when I noticed one of these beantifully marked hirds moving about in a pear tree just outside the window. Etiquette was forgotten for the time, and we all jumped up and watched our pretty visitor for a few minutes till it flew out of sight. There is no other record of the bird occurring here so late in the season, and I cannot account for it at all, as the specimen was fully plumaged and not a late hatched young one. It comes to this country from Australia about October and leaves as a rule early in Jauuary. The migration of birds from Enrope to Africa, and vice versa, and between Asia and Australia, is a mere nothing to the flight involved in the migration of our cuckoos, which must cross at least one thousand miles of ocean at one flight.

The list of our bird visitors in this month includes chaffinches (which are however, unaccountably scarce now as compared with their former abundance), greenfinches, and a stray parakeett or two. These latter were formerly the commonest of our visitors, but now one has to go right away from the busy haunts of men to meet with them. It is more than eight years since the last more-pork $k_{+}^{+}$was heard in the district, but only last summer two of the large white-faced owls spent a night in the trees in the garden and surprised the whole neighbourhood with their calls. In the fields adjoining the garden are numerous skylarks and an occasional native pipit.|

The abundance of bird life, especially of introduced species, has very sensibly reduced the annount of insect life, yet the kinds of insects still to be seen are very numerous.

\section{* Chalcococcyx lucidus.}

+Cyanorhamphus Nove-Zealandia. \$Sceloglaux albifacies. ¥Ninox Nova-Zealantia. HAnthus Nova-Zealandia. 
Again, however, it is the introduced kinds - the hive bees, humble bees, and flies-which are most abundant in individuals if not in kind, or at least which are most in evidence.

\section{II.}

I wituesser recently in the garden a domestic tragedy on the small scale such as may often be seen at this time of the year-a spider-hunting wasp dragging a victim over the ground to its hole. People frequently ask if we have wasps in New Zealand. There are certainly no species of the genus Vespa, to which the European wasps and hornets belong, but we have wasp-like insects - active restless creatures, loving the sunshine, and armed with a sufficiently formidable sting-which are often to be seen in the summer, especially on bright hot days. Several species occur in this neighbourhood, and two are common enough. The larger species*_a dangerous-looking insect about an inch long-is to be seen frequently in wooded valleys as if it were fond of warm sheltered spots; the more common onet met with in my garden is the smaller form, not more than half an inch in length. It is a most restless insect, often lighting down on the ground or on a stone as if to take a survey of the game in the neighbourhood. When it sees a hapless spider it instantly attacks it ; springing on its back and curling round its abdomen it stings its prey right in the middle of the thorax. The spider is not killed, but it is thus completely paralysed, and is dragged to the burrow of the wasp. This burrow is sometimes in the ground, sometimes in a log. Into this the wasp pushes a number of paralysed spiders, and when the hole is sufficiently provisioned according to her ideas she lays an egg in it. The wasp-larva as it develops eats up its half dead companions, and presumably by the time it has eaten them all up is ready to emerge and start spider-hunting on its own account. 'This seems a much superior device to either freezing or tinning one's meat ; it certainly has the merit of being much older. It

* Salius fugax. $\quad+S$. monachus. 
is also a curious case of turning the tables on one's enemies with a vengeance, for spiders are always associated with our ideas of cool calculating blood-thirstiness, and to have them hunted and eaten in this deliberate way by other insects seems to be a just judgment on them. The spiders have an instinctive dread of these wasps. Even large trap-door spiders, big and strong enough to smash their opponents with one blow of their powerful falces, seem to throw up the sponge as it were at the first sight of a wasp. They become weak-kneed, and limp, and run in a helpless kind of way, till their active black enemy pounces on them and quickly gives them their first, which is also their finishing, stroke.

\section{III.}

There is nothing more delightful than climbing on the mountains when the flowers are in bloom,-aye, even when they are not,- and getting right away up into the open, where the air seems to be freer and the world becomes so much larger to the view. It is infinitely better than pursuing a white ball on the breezy downs, invigorating as that pastime undoubtedly is. Those who live on the lower levels and have never tasted the joys of a walk on a mountain side have missed one of the true pleasures of life-the kind of pleasure that brings no pain, but only such fatigue as causes deeper sleep and stronger pulses of health.

This is the time of year to climb the hills and see the beauties of nature on the mountain tops. Those who only know the native vegetation at sea level have little idea of the wealth of flowers which is met with at high elexations in this country. At a height of from 4000 feet to 6000 feet there is a new flora, of which the flowers are certainly nearly all yellow or white, or faintly tinged with blue, but very heautiful individually and in mass, and often very fragrant.

But even about our own romantic town, though it is only possible to reach a height of a little over 2000 feet, the climb is well worth the effort and brings its own reward. 
One recalls many such a ramble on the hills in January, when

$$
\text { "A dreamy haze }
$$

Played on the uplands, but the hills were clear

In sunlight, and no cloud was on the sky.

It was a time when a deep silence comes

Upon the summer earth, and all the birds

Have ceased from singing, and the world is still

As midnight, and if any living thing move

The ear can catch the rustle, and the trees

And earth and air are listening."

The Epic of Hades: Marsyas.

But seldom in New Zealand does the summer air such "a solemn stillness hold"; it is its wont to be in ceaseless motion, now gentle and now rough, but ever stirring. But when nearly still the very joy of life seems here, - the air is full of "a tender music, like the Eolian chords," the hum of countless insects as they move on restless wing.

Before we seek the breezy uplands there are flowers in the bush that come out late in the season, some of which are very attractive. The houhere (Hoheria populnea), with its pretty white starlike blossoms, is one of the most noticeable of the small trees in the bush. It seems to grow best on rocky ground, such as the sumny slopes of Woodhaugh or the top of Saddle Hill. The local variety is a small-leaved form, and it is interesting as showing in its adult condition the same kind of foliage as characterises the common ribbonwood (Plagianthus betulinus) in its juvenile stage. Perhaps it represents an ancestral leafform. But while the houhere has a very conspicuous flower, the ribbonwood has lost its attractiveness of colour and size, and bears clusters of small greenish-yellow blossoms. Another Plagianthus (P. Lyallii), * the mountain ribbonwood, is in flower this month, and is met with in cultivation in many gardens. Its native habitat is in the valleys and lower woods of the western mountain districts, throughout the whole length of this island. In "The

* Now known as Gaya lyallii. 
Handbook of the New Zealand Flora" it is said that " $\mathrm{Mr}$. Haast informs me that this forms a deciduous tree at and above 3000 feet, but is evergieen below that level; in autum its naked branches and yellow foliage give a

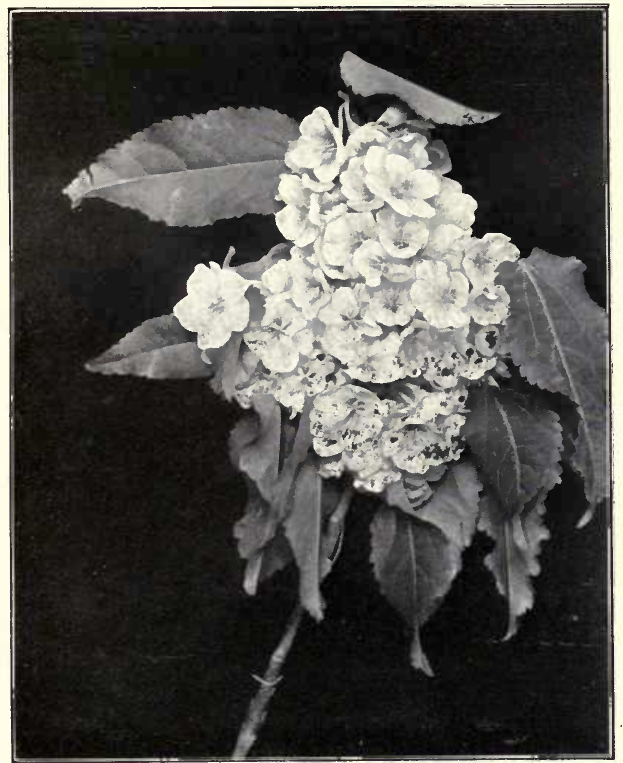

Plugianthus (Gaya) Lyallii.

peculiar colour to the landscape at a higher elevation." Haast was speaking probably of North Canterbury, for in local gardens it seems to be quite deciduous even at low levels. The northern tree, as cultivated in Chiristchurch gardens, differs in several small details from the Otago form, 
The kamai (Weinmannia racemosa) is a tree which occurs very abundantly, particularly in the southern parts of Otago, and not far from the sea coast. It used to grow at the head of Dunedin harbour, but has long ago disappeared. It and Carpodetus serratus, a small tree with

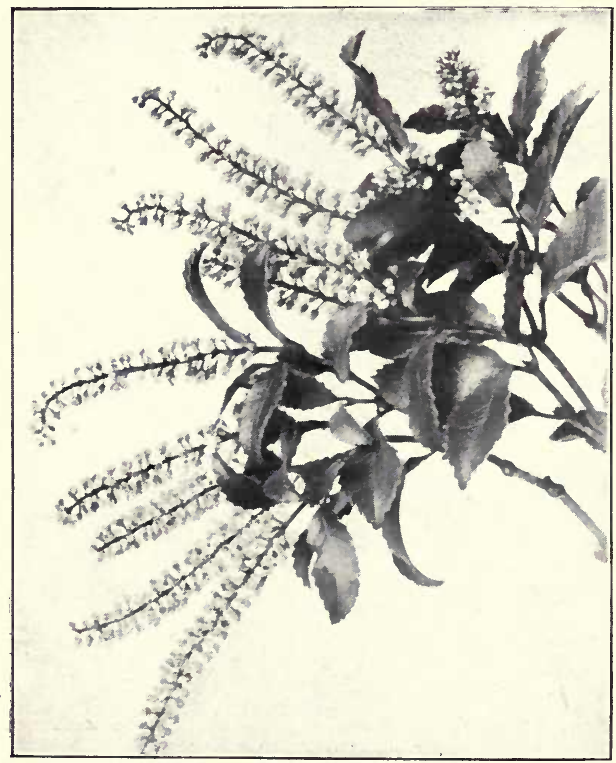

Kamai (Weinmannia racemosa).

creamy white flowers, which blooms freely during this month, both belong to the woody section of the great natural order of Saxifrages. But while the small herbaceous types of the order are almost confined to the temperate regions of the northern hemisphere, these 
woody forms are entirely southern. Carpodetus is allied to the common Escallonia of our gardens, as a comparison of the flowers will show.

The two native myrtles which occur in this island (Myrtus obcordata and M. pedunculata) both flower in January. All plants of the myrtle family have one characteristic feature in common, though it is by no means confined to them - if held up to the light their leaves are seen to be full of clear spots. These are little cavities in the leaf-tissue which are filled with an oily fluid, and it is this which gives the translncent character. Our two myrtles are not only distinguished by their leaves- $\boldsymbol{M}$. obcordata having heart-shaped leaves with a deep notch at the apex, and $\boldsymbol{M}$. pcdunculata having rounded apices, - but also by their berries, the former being black or violet in colour and the latter orange-yellow.

As one comes out on the more open ground above the bush, when climbing the hillsides, there is generally abundance of native flax-Phormium tenax - to be found in flower. Phormium is a curions genus only found in New Zealand and Norfolk Island, and therefore probably of considerable antiquity, but distantly related to the beautiful Blandfordirs or Christmas Bells of New Sonth Wales. Its dull red flowers are not very attractive in colour, but they contain a great quantity of nectar, and in haunts undisturbed by men they are visited by numbers of native birds, not only tuis and korimakos, but kakas* and parakeets, all of which brush the abundant sweet fluid out of the blossoms. The genus has in all probability developed its extremely tough leaves partly as a protection against moas, and partly as a protection against excessive exaporation, though this is only a matter of conjecture.

Among the flax occur many small tree-ferns belonging to the gemus Alsorhila, so called from two Greek words meaning grove-loving; but the only New Zealand species

\footnotetext{
* The Kaka or Bush-parrot (Nestor meridionalis).
} 
(A. colensoi) grows out in the open ground. Its stem seems to stand a foot or two above ground, but it is really a prostrate species, with a trunk often 10 feet long, but only the upper portion stands erect.

High up among the hollows on the hillsides are great swathes of the rich lout delicate-green frouds of the millfoil fern (Hypolepis millefolium), its fronds cut and crimped into a thousand small segments. One wonders bow such a rich and luxurious growth can preserve its beauty and delicacy in such high and exposed situations; but this fern, like some other's of fine textme, dies down in the autum, leaving a thick mantle of dead fronds to protect the creeping stems during the months of snow and frost, so that the new growth of early summer comes up fresh, soft, and of a vivid green hue. These soft-fronded ferms will not stand the hotter dry air of the northern hills and ranges of this islaud, and " "nor'wester" shrivels them, but under the "cheerful grey skies" of Otago they thrive to perfection.

There are usually plenty of flower's on the open hillsides during January. S'enecio bellidioides makes the ground gay with its bright dandelion-like flowers, while the common native everlasting Helichrysum bellidioides produces gieat trusses of small white-bracted blossoms. It troubles sonie people to use the only names by which so many plants are known, and they are given to carping at them. But seeing that none but botanists have taken the trouble to invent names for them, and that they have done so in accordance with certain simple rules of nomenclature, the cavilling is ungracious. Whenever the poet shall arise who can suggest simple appropriate and euphonious names for all the native plants, names that can be "understanded of the people," then we shall hear him gladly, and perhaps adopt his names. Meanwhile it may simplify these technicalities to try to arrive at their meaning : thus Bellis is the technical name of the daisy, and bellidioides means "daisylike." 
In moist ground are still to be met with numerous small delicately scented violets, white with blue or purple stripes on the lower petals, and yellow throats; while on the drier. knolls are the little white flower's of the only native mint (Mentha (uuninghamii), a plant somewhat suggestive of the wild thyme of the Old Country. Native blue-bells, which, however, are more often white; Pratia, a small white lobelia-like plant, and small composites of several kinds (Celmisia, Lagenophora, Vittadinia, and Raoulia) are all common in January. Occasionally one comes across

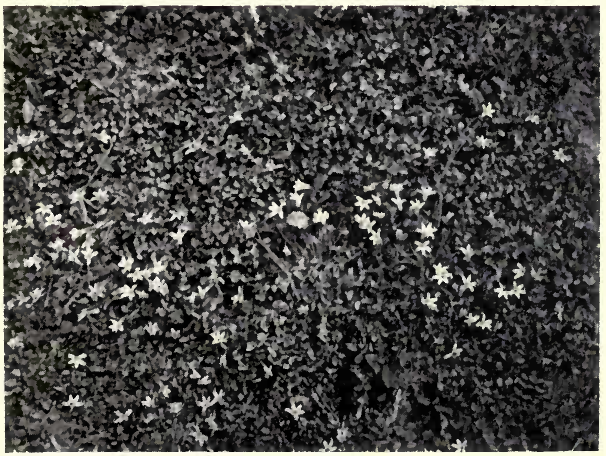

Pratia angulata.

the little native carrot (Daucus brachiatus), or the diminutive liliaceous Arthropodium candidum. This bears pretty little white blossoms with curiously tasselled stamens, but very frequently we meet with a grass-like for'm which produces closed (cleistogamic) flowers destitute of white colour or fragrance. The commonest orchids are mostly inconspicnous green species like Microtis and Prasophyllum, but one also meets with the large interesting green flowers of Pterostylis, which temporarily imprison the flies which visit them, or the blue Thelymitras. Chiloglottis traversii 
and two small species of Caladenia have delicate whitish flowers, which under a magnifying glass reveal themselves as marvels of beauty. At elevations above 2000 feet a more typically Alpine flora is met with, such as the box-leaved

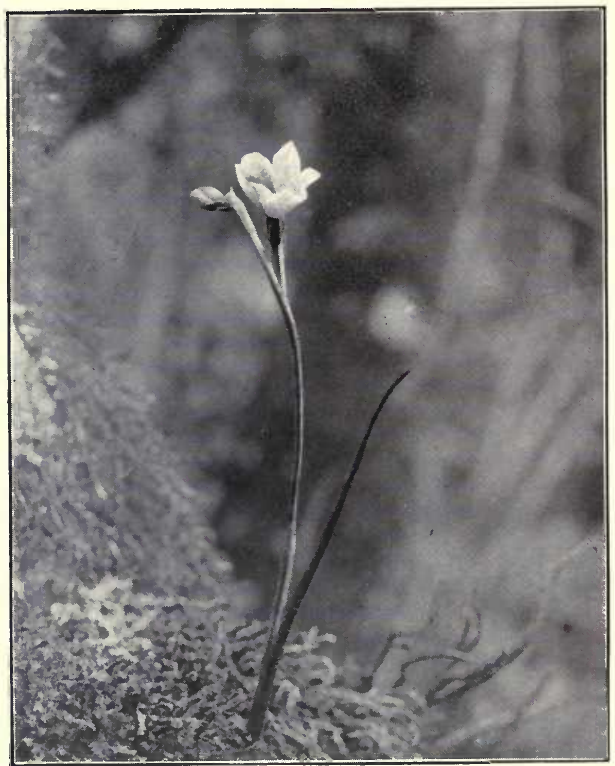

A common blue Orchid (Thelymitra pulchella).

and other Veronicas, patches of white-flowered Forsteras and Helophyllums, a small eye-bright (Euphrasia antarctica) and many others. On warm days it is marvellous, too, what a wealth of insect life exists among these flowers, how the small but exquisitely coloured butterflies and more 
sombrely-clad moths play in countless numbers over the upland slopes or chase each other from flower to flower, while beetles, flies, and other kinds of small game abound.

January is the month of the year in which the naturalist finds the greatest profusion of animal and vegetable life, and it is perhaps the most interesting time of the year for the student of Nature.

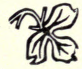




\section{Chapter IV.-February.}

I.

Tho write a Calendar which is even approximately 1 accurate as a record of natural events is somewhat difficult anywhere, and is particularly so in a country stretching through such a range of latitude as New Zealand does. Some districts are months rather than weeks in advance of others as far as vegetation is concerned, so these notes must be taken to apply only to Dunedin and its immediate neighbourhood in reference to this aspect of nature. But while this diversity in point of time is true for the vegetable kindom, we find that another seasonal change, marked by the migration of birds, is much more uniform for the whole comtry. This subject, so far as the New Zealand group of islands is concerned, is not very much known, and it is one which might well enlist the assistance of those interested in bird life. In Britain, where the observers number thousands, the dates and conditions of migrations of bird life are beginning to be well understood, but in this colony, where there are so few qualified observers, the wonder is that so much good work has been accomplished as the records show to be the case. Lighthouses are most favourable vantage points for watching the migrations of birds, and some of those on the New Zealand Coasts are particularly well suited for the work. There have been several good observers among the lightkeepers, and in an occupation which must often prove very trying from its monotony the interest which the recording of natural phenomena displays must prove a valuable thing to the possessor. Frequently when birds are arriving from an oversea flight they are caught or seen in the neighbourhood of a lighthouse in a more or less exhausted condition, so that it is usually more easy to fix the date of arrival of a species than its departure, unless the latter takes place in flocks, when they gather together 
in some conspicuous place for a few days before taking their final flight.

The cuckoos are the most familiar examples of migratory birds, the long-tailed species coming to these islands from its winter home in the Pacific Islands, while the shining cuckoo migrates between New Zealand and Australia or perhaps New Guinea. The long-tailed 'nckoo usually leaves New Zealand for its northern habitat during this month of February, being very seldom heard later; while the shining cuckoo is considerably enrlier.

Besides the cuckoos, there are numerous kinds, principally of shore birds - plovers, sandpipers, snipes, godwit, curlews, and allied forms - which are probably all migratory. They differ, however, from the former in one important particular, namely, that whereas the cuckoos come here to breed and to spend their summer, the others mostly visit these shores to avoid the northern winter, returning - in some well authenticated cases - to the lakes and tundras of Siberia and other far north regions to spend their summer there.

Dwellers in town have not much chance of watching and recording the habits of birds, but those who live in comintry districts and by the seaside have frequent opportunity, and if their observation is aided by a good fieldglass it is wonderful what an amount of knowledge they can accuire about their feathered visitors.

\section{II.}

February is a month of ripening fruits and seeds, and although in many instances this phase of plant life seems to have little to attract the naturalist, yet to the eye that looks below the surface of things there is as much to wonder at and admire in antumn as in any other season of the year. Perhaps at no other time is the fact of the struggle for existence among plants lrought home more forcibly to the observant mind. The main object of existence among all organisms seems to be to reproduce 
their kind, and this is more conspicuously manifested and more easily observed among plants than among animals. Those who study human statistics know that the death rate among infants is high, and that the rate diminishes as the adult stage is approached, a very considerable proportion of children born into the world growing to maturity. But on looking into the conditions of life among the lower animals and plants it is fomd that it is not the few which die and the many which survive, but that a very minute proportion only of the progeny survives to maturity, while an enormonsly vast majority die in the course of their individual development. Figures are not available for plants; they may have been worked out by some of those patient Teutonic observers who mine and fossick in all sorts of dust heaps, only I cannot lay my hands on them at present. Yet one has only to cousider any fruiting plant to notice what an enormous discrepancy there is between the seeds produced and the resulting mature plants. To anyone who has time for such an experimentand it will be found a more instructive exercise than worrying out the inane puzzles which are so commonly propounded in magazines and other ephemeral literature 1 recommend the following:-Take a foxglove plant which is nearly past flowering, and, picking a ripe capsule from near the lower end of the raceme, count the contained seeds. 'Then multiply this number by the number of capsules borne by the plant, and the resulting figures will be found to be very large. If all the foxglove seeds ripening in and about Dunedin during this month of February were to produce mature plants, it is certain there would be no room for any other kind of vegetation. Yet the foxglove is not one of our commonest plants. But there is no reason to believe that the number of these plants which will be found a year hence will be much larger than it is now. The inference, then, is that the vast majority of the seeds now produced are doomed to destruction. It was from a contemplation of facts like this that I)ar'win was led to his views on the "struggle for existence" and the "survival of the fittest." 
The number of plants which produce seeds in vessels which open is very great. It includes nearly all the family to which the foxglove belongs, such as frogsmouth, Veronica, etc., also such familiar plants as poppies, mignonette, wallflower, chickweed, and countless others. As the seeds ripen they drop all round the parent plant, so that the struggle for bare life is most severe among closely related individuals of the same species. Most plants which do this are either anmuals or biennials. As a rule they have feeble powers of dispersion. Just imagine a tradesmaul, say a grocer, with half a dozen sons, establishing them all as grocers immediately round his own shop. One of the lot might survive, or even two might suceeed in a fashion, but the majority would succumb. Yet a poppy will drop 10,000 seeds round its dying stem, and if all germinate there will necessarily be a very high death-rate before the few survivors reach the flowering stage.

Frequently plants with dry seed vessels are provided with devices for scattering the seeds. Clematis and Anemone, and many composites like thistles and dandelions, develop some sort of feathery appendage either on the seeds or on the fruit, and this serves to distribute them by the agency of the wind. Others have their fruits or seeds flattened out for the same purpose, such as the Norway maple, honesty, and the New Zealand flax. Others, again, throw away their seeds to some distance, a fact familiar to the most unobservant in gorse and broom, whose pods crack with a little report on still hot autumu days.

Then there is the vast class of plants with succulent fruits, which are so developed that they may be picked or swallowed by birds and so distributed. Large fruits of this kind are not swallowed, of course, but fruit growers know that when a thrush or a blackbird is disturbed at the morning's meal on the peaches or apricots it will sometimes thrust its beak into a fruit and fly away to some sequestered spot to pick the succulent part off the stone. Small fruits, and especially berries, with several seeds in them, are swallowed holuş-bolus, and this accounts for the increase of elderberries in the 'Town Belt, as well as of fuchsias, 
hina-hina,* and many others of the same type. By the introduction of fruit-eating birds into the country the spread of such plants has been greatly increased.

Lastly there are a few plants whose fruits or seeds catch on to passing animals, and are thus carried about. These are necessarily few in a country which possesses no indigenous terrestrial mammals. But an examination of a common piri-pirit (vulg. bid-a-bid) will show that it is singularly well adapted for this mode of distribution, and that the barbs which are so troublesome to the picnicker are exquisitely formed little anchors of the most perfect construction.

\section{III.}

A common visitor in many gardens, especially those having a sunny exposure, is a burrowing bee, technically known as Lamprocolletes fulvescens. I have never found it in my own garden, which slopes in a south-east direction, whereas I only remember to have seen this insect on northerly or north-westerly exposures. The mature insect is only to be found in summer, and very much has still to be learned about its life-history.

In December or January (perhaps earlier), on a bright sunny day, the surface of a firm earth or gravel path may often be seen to be covered with little mounds from a half to one inch in height thrown up beside a small hole. While looking at these, a small light brown hairy Bee, not much more than half an inch long, lights down near one of them, and, after looking round to see that the coast is clear, runs quickly forward and pops down the hole. Probably the insect is yellow with pollen, and bears a couple of balls of pollen on its hairy hind legs. If one is watched emerging from the hole, the pollen is seen to be gone; the insect has made away with it somehow or other. On flying away, the bees proceed at once to visit the flowers near at hand, being particularly fond of marigolds, summer chrysanthemums, and other composites, all of which pro-

*Melicytus ramiflorus. + Acana sanguisorba. 
duce large quantities of pollen. I have also noticed them on Indian pinks, Godetias, and other flowers, and in the large yellow fragrant blossoms of a common evening primrose have seen them apparently stupified or intoxicated. Yellow seems to be their favourite colour.

The holes are excavated more or less obliquely in very firm ground, such as well-trodden paths, or hard clay banks, but never in loose soil. They vary from two to four inches in depth, are circular in section, with smooth walls, and have no lining. Each ends abruptly without enlargement, but frequently the bee makes more than one chamber at the extremity, but it always closes up all but one. When the hole is made (I may say I have never seen the process of excavation going on) the insect seems to spin a sort of membrane or bag into which it collects the pollen which it has accumulated on its hairy legs. When a pellet rather larger than a pea has been gathered, the bee lays an egg in the mass, rolls the membrane round it, and closes the orifice. This at least seems to me to be the process, but my examinations have been very cursory, and the results want confirmation. I have looked into the holes during the months named, and have never been able to follow out a series of consecutive observations. Many of the holes are found to be quite empty, others have balls of pollen in them, while others have larvæ in various stages with the pollen a good deal eaten. In one hole I found a well-developed insect, apparently in the pupa stage, with a rather ferocious-looking head, and no pollen beside it. Had it not been among the holes of other bees I would have taken the insect to be the grub of a tiger beetle. I have taken out balls of pollen and kept them in looselycorked tubes to see if I could observe the development of the insect, but my results were always rather suggestive of the duck which Tom Brown wrapped in paper and put away in the cupboard - the pollen always decayed and grew a crop of mould, but no insect ever appeared. Here is a nice little piece of research work for some embryo naturalist to undertake and follow up ; all that is wanted is to take a careful set of observations, and we shall soon 
come to know the life history of Lamprocolletes. What a name! These bees are not early risers ; they do not seem to come forth till about 10 or 11 o'clock in the forenoon, and disappear on a threat of rain or if the day becomes cold or orercast.

If a flower-pot in one of the frames is lifted, one is sure to disturb a great number of wood-lice, which quickly betake themselves in all directions for shelter. Some of them stay still for a while, trusting to that wonderful instinct by which many animals seek to evade their enemies, an instinct which leads some to sham death and others to stay still in such a position that their resemblance to their surroundings hides them. The woodlouse,-or slater as it is often called, - is not an animal of high intelligence, but it seems to have enough to know that it is sometines a wiser plan to stand still than to r.un away.

I don't come across many people who are interested in wood-lice. Strange want of taste, is it not? They are too creepy, they seem to have too many legs, and superfluous legs are uncanuy things, and they don't seem to have any special role in nature except to be where they are not wanted. Gardeners have a great antipathy to them, and credit them with a good deal of damage which they do not do. For my part I find them very interesting, and will try to show why. In the first place, they are not insects at all. They belong to the crustacea, the same family which includes the crabs and crayfishes of the coast, and of which some hundreds of species are known in New Zealand. They belong to the group known as the Isopoda, or equal-footed.

The best way to examine the structure of a wood-louse is to drop it into a little spirits of wine, which will kill it in a few seconds. Looked at from above, the body is then seen to be made of a number of segments or divisions. In front is a square head which is really formed by the union of several body-segments; this bear's the numerously-jointed antennie, and on the underside the mouth organs. Behind the head are arranged seven hard plate-like divisions, evenly granulated and sculptured on the back, and so 
placed that each plate overlaps the one behind. This jointing of the thoracic portion gives great flexibility to the body, while at the same time the soft parts underneath are protected by a coat of mail. Behind the thorax come six smaller joints, the last of which is very small and ends in a sharp point; these form the abdomen. If the creature is turned over on its back we notice that there are seven pairs of similarly formed legs, one underneath each of the thoracic segments; while under the abdomen there are five pairs modified into plates and acting as gills or breathing organs, while the sixth pair is also plate-like, but the plates project out beyond the last segment, like fans. In all the Crustacea the ways in which the different appendages of the body are molified are endless; in some they act as organs for masticating the food or catching the prey, in other's for defence, walking, swimming, burrowing, breathing, or in connection with sexual functions. Thus if the wood-louse happens to be a gravid female it will be found that to each of the thoracic legs there is attached a broal flap-like piece, and these seven pairs of flap-like processes form a brood-pouch within which the animal carries a large number - a hundred or more - of eggs.

It would be interesting in connection with these creatures to show the gradual steps, as exhibited in the life-histories of their numerous relatives, by which a marine waterbreathing animal has come to be terrestrial and chiefly air-breathing, but this would take us quite outside the limits of our field work, and the temptation to indulge in what is a laboratory question must be restrained and for the present set aside. The common wood-louse of our gardens is not a New Zealand species at all ; it is a common European form (Porcellio levis) which is found in most temperate regions of the world where Britons have settled. It has no doubt heen brought across the seas along with plants or roots. I have gathered this species in Melbourne and in Hobart, as well as in many parts of this colony.

There is one other species of crustacean * to be found in 
our gardens, though it is much more abundant in the bush anong dead leaves, rotten wood, etc. Frequently when one disturbs such material, or when a bunch of cocksfoot grass is pulled up by the roots, a number of small brown hoppers are exposed, and these either wriggle away on their sides or spring off to a distance of some inches and then squirm out of sight. Occasionally one lies quite still on its side as if dead, and then, finding that it is not further molested, rises quietly and walks off to convenient cover. These hoppers belong to a different group from the woodlice-namely, the Amphipoda, so called because they have both walking and swimming legs. Their bodies are flattened laterally, so that though they can walk erect, they can more quickly wriggle away on their sides. Of their. seven pairs of thoracic legs, the first two are usually very feeble; the next five are for walking, two having the claws directed backwards and the other three forwards. The abdominal appendages are quite different from those of the wood-lice, for the first three pairs are in most Amphipoda used as swimming organs, but as our hopper has become adapted to terrestrial life these limbs are reduced very much in size and have become functionless. The last three pairs are short and stiff, and only serve to help the creature to jump. When a Crayflsh is desirous of escaping quickly in the water it whips the abdomen with its large tail fin under the body with such force that the animal is propelled backwards with a rapid jerk; but when a hopper wants to escape it brings the tail smartly down on the ground and so leaps upwards and forwards. The breathing is accomplished by gills which are attached to the thoracic legs.

These hopper's which occur in our bush and in the gardens are also found in Australia and Tasmania in similar localities. I lave picked them up on the slopes of Mount Wellington, close to Hobart, and I have plenty of specimens in my collection which were gathered in New South Wales. It is interesting to speculate as to how a creature which drowns in two or three minutes when placed in sea water, comes to be found in localties separated 
FEBRUARY.

6 I

by a thousand miles of ocean. I cannot say, like the novelists, that the answer to this question will be found in our next, but I hope in further notes to show that this is not an isolated phenomenon, and so we may be able to get a little more light on an important question in geographical distribution. 


\section{Chapter V.-March.}

I.

The exceptional amount of sunshine which we have enjoyed this season has matured most things at a date considerably earlier than has been the case for several years past, and this fact has been conspicuous everywhere. The ripening of the grain in the fields and the fruit in the orchards has produced an abundance of food for birds, and this has shown itself, among other ways, in the neglect of certain substances which they usually affect. It is the first season for a long time that the fruit of the rowan or mountain ash has been allowed to ripen on the trees and to beantify the landscape by its brilliancy. This fruit is extremely astringent, but when other food is scarce blackbirds and thrushes eat it as fast as it turns red. This season there has been so much that is more attractive and tasteful that these birds have left it alone, preferring plums and other luseious fruits, which have also been very abundant.

An interesting suggestion on the subject of weather, which I commend to those who care to investigate the matter, is to find out whether it is the case that when the Australian Continent suffers from prolonged drought, New Zealand gets too much wet and cold weather; and, conversely, when Australia gets too much rain these islands enjoy a drier and warmer climate. Our past cold seasons have been drought years in Australia; this year is an unusually wet one on the other side of the Tasman Sea, and a dry one in New Zealand. This is probably more than a coincidence, though it would require a careful examination of meteorological records to establish the truth of the hypothesis. At the same time, the suggestion is a highly probable one, and the explanation of it would have to be looked for within the Antarctic circle. When vast masses of ice are disengaged from the sonthern ice-cap 
and float north in the direction of New Zealand the whole body of ocean water surrounding these islands is lowered in temperature, and as a consequence the atmosphere over this body of chilled water is considerably cooled also. If, on the other hand, the main disengagement of ice takes place some hundreds or thousands of miles further west, and the Southern Ocean between Kerguelen Island and Australia is cooled by icebergs, then the temperature of the air, especially in the coastal regions of Australia, will be correspondingly lowered, and much more wet and cold weather may be expected there. Some such explanation may be the right one for the present distribution of fine and bad weather in these southern regious.

II.

March is perhaps the best month in the year for collecting ferns, for nearly all the species are now to be found in spore. Spores are not seeds, though they represent one of the reproductive stages of the plant. Let me try to make this clear. In an ordinary flowering plant, such as a poppy, two kinds of reproductive cells are produced within the same flower, the male element being found within the pollen grain, and the female within the little rudimentary seed or ovule, which, again, is enclosed in the pistil. By the interaction of these cells a new germ is produced, which is nourished and developed to a certain extent within the parent plant. The extent to which this development is carried varies in different plants. Some, like peas and cabbages, develop the embryo to a very large extent, so that within the mature seed may be observed a little stem, two leaves, and a rudimentary root, the leaves usually containing some nutrient material for the future plant to feed upon. In others, like buttercups, the embryo grows to a very limited extent; it is left almost undeveloped, and there is laid up beside it a little store of food material for it to feed upon. Every seed, then, represents a young plant which has been reared up to a certain point by the parent organism and which has entered upon a resting 
stage. In this condition it is cast adrift to enter upon a separate and independent existence.

But in flowerless plants like ferns an altogether different mode of reproduction is net with. On some

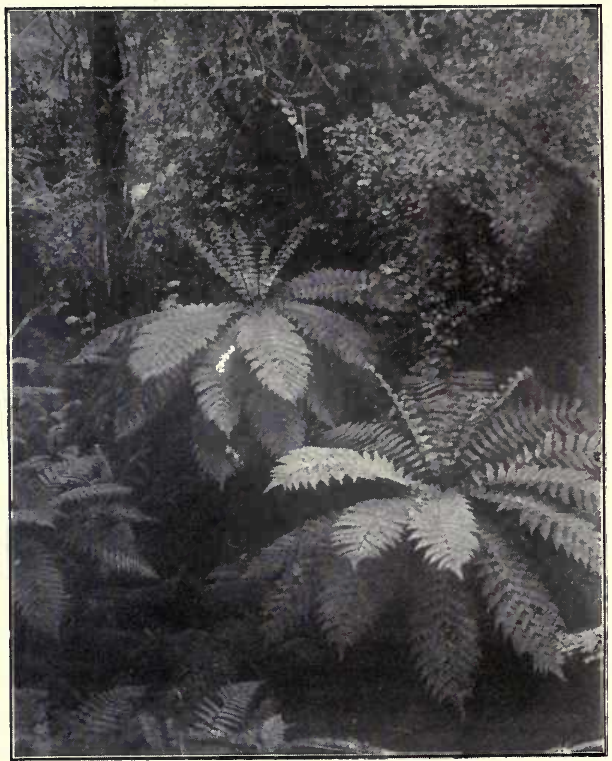

A Bush Scene with small Tree Ferns.

part of the frond there are produced small outgrowths of the exterual layer of tissue, which are technically known as sporangia or spore-cases. Inside of these little sacs very small cells are produced, which are the spores. These have a purely vegetative function. When placed in favourable conditions of moisture and warmth they send 
out a small shoot which grows into a minute green plant of very simple structure-a mere flat plate of cells. This little organism probably represents a primitive stage of existence through which the ancestral forms of all ferns have passed. It bears two kinds of microscopical cells, male and female, in its tissues, and by the mutual action of two of these an embryo is developed out of which grows a new fern plant. These little rudimentary fern plants may be found in abundance in damp spots in spring-time; but at this season of the year the only thing to be found is the mature fern plant with its brown cluster's of spore cases.

Ferns are classified by botanists mainly by the position and mode of development of these spore-cases. In the delicate filmy ferns, the fronds of which are only a very few cells thick, the tips of the fine divisions of the blades divide into a sort of flap, inside of which stands the little brown cluster of spore-cases. In common bracken and its allies the edges of the fronds are folded back and the sporangia lie in rows inside the folds; while in the Polypodies, such as the common climbing form that is so abundant on tree trunks, they are grouped in rounded clusters on the backs of the fronds. These are only a few of the arrangements which occur.

When a spore-case is ripe it is burst open by the shortening of an elastic band at the back, and numerous little spores are east forth. Where ferns, especially bracken, are very abundant, as on the lower hills round the great southern lakes, * the scattering of the spores occasionally produces curious effects. The fine dust is so difficult to wet that it gathers on the surface of the lakes in a thin film which glistens in sunlight like a sheet of burnished copper, and in shadow gives a deep red-brown hue to the water. When several square miles of lake surface are thus transformed in the sloping rays of the sun the effect is said to be very remarkable and almost awe. inspiring. I have not myself seen this phenomenon on a large scale. 
Flowers become rarer as the autumn advances, but there are always numerous kinds still to be obtained, especially at high elevations. I have recorded as many as forty-two species flowering in this neighbourhood during this month of March, and these can only be a small proportion of the total number, as at this late season of the year a collector is seldom on the lookout for flowers, and passes over without notice many which were met with at an earlier date. Among late-flowering plants two or three are of especial interest. Thus March is the usual time to find the autumn-flowering Earina (E. Autumnalis), one of the prettiest of local orchids, in blossom. It is one of the epiphytic forms, growing on the surface of rocks and on branches of trees. Its roots are exclusively ærial, and their white tips are enclosed in a thick spongy tissue which has great power of absorbing moisture, but, apparently, does not again part with it by evaporation. The white waxy flowers are very fragrant, and are quite incapable of self-fertilisation. They must therefore be visited by insects-probably small flies-before they can set seed.

Native gentians, too, mostly flower this month, and their white blossoms make the uplands quite gay. An introduced allied plant, the centaury (Erythrcea Centaurium), is often very much in evidence in pastures both the pink and the white-flowered variety-its bitter juice rendering it distasteful to all grazing animals. The native poro-poro (Solanum aviculare), whose name is often corrupted into bulli-bulli, flowers late into autumn. It is a true potato, as can easily be seen by comparing its flowers and fruit with those of the common edible species.

\section{III.}

I have notes of numerous birds visiting the gardens during this month of March, no doubt for the sake of the fruit still to be found there. In early days kakas and parakeets used to be recorded, but it is many a day since even the latter were to be seen near Dunedin. But tuis and korimakos having now reared their young broods 
come more about dwellings, while wax-eyes are frequently very abundant. These latter are among the useful visitors in the garden and orchard; they are continually busy allong the foliage and branches of trees in search of small insects, from which habit they have acquired one of their popular names, that of blight birds. Among introduced species I find several records of chaffinches seen in the month of March. The way in which these pretty birds appear and disappear in various districts is worth recording.

Has anyone seen robin redbreasts recently? A young friend told me that when walking over Flagstaff Hill with a companion two strange birds flew close to where he was, near enough for him to notice that they had bright red breasts. He thought they were about the size of small sparrows. Considering that no less than forty of these birds were liberated in the neighbourhood of Dunedin in 1885, and twenty more in the following year, it is rather remarkable that (as far as I know) only one record of their appearance has been made since-Mr A. C. Begg having seen one in his garden in Roslyn several year's ago. The birds seen on Flagstaff Hill were probably red-poles, which are common along the east and south coasts of this island.

Insects are relatively abundant in March. About this time of year a small stinging fly, appropriately named Stomorys, makes its appearance, especially in country districts, and irritates both man and beast. Probably it is well known to many. It is rather smaller than a housefly, quicker in its movements, and when it lights down on its prey it makes a clean puncture, and, if undisturbed draws a little blood. It can stab throngh a single garment, and is fond of attacking the legs.

Drone flies, which resemble hive-bees except in the slowness of their flight, also appear this month, though they are commoner later. Their larvæ, which resemble large maggots with rat-tails appended, are commonly found in stagnant water. Moths and butterflies of many species are also abundant. The latter group is not represented by many species in these islands, and near the 
coast only one very conspicuous form, the so-called " Red Admiral" (Vanessa gonerilla), is well known. But in the drier inland districts numbers of small gaily-coloured butterflies of prevailing lilac-blue, brown, and reddish hues, are met with among the tussock and scrub of the hillsides. Their eggs, laid among the vegetation close down to the ground, will lie dormant till the heat of next summer hatches them out.

\section{IV.}

In March, even more than in February, the season of autumn fruits, the season of in-gathering has come, when plant life, with that strange mysterious action which looks so like reason that we use of it almost the language of reason, begins to prepare for its period of rest, and when man, taking advantage of this action, lays up for his own use the stored treasures of the vegetable world. There is present in every living organism a force which causes it to make provision for the continuity of its kind. Its life-work seems to be the perpetuation, not of its individual self, but of its race, and all its powers are devoted to this work. The law which stands out most prominently in the study of living organisms is not the survival of the fittest in the struggle for existence (prominent as that is), but the sacrifice of self for the benefit of the race. The deeper we look into Nature's workings the more forcibly will this truth appeal to us.

It has been repeatedly pointed out that there are far more individuals of all kinds, plants and animals alike, born into the world than can possibly come to maturity, and that there has thus arisen a fierce struggle for existence which manifests itself in the production and development of modifications of structure tending to the better equipment of the individuals for their part in this struggle. Innumerable myriads of organisns are all bending their energies in the direction of the better waging of this struggle. Whatever does not make for progress is severely eliminated, while all that aids an organism in this life and death contest tends to be increasingly developed. These 
are some of the prime factors which have fashioned the world of living things which we see to-day, and these forces are still at work continually around us.

The adaptations whereby plants secure the most favourable conditions for the seeds which they produce are so abundant and so easily studied that we may well devote a little attention to them at this season of the year. I have referred to them in last month's notes, but only to a slight extent.

In the course of our walks through the Town Belt or along the suburban roads we must have heard, on the few bright days we have enjoyed this autumn, the pods of the broom and the whin cracking sharply, and if we have had the patience to stand for a minute to watch and listen, we would have probably noticed that the seeds were thrown out to a distance of several feet. As the pods come to maturity their inner lining becomes tense and elastic, so that when the sum shines strongly on them and the air is dry, the pressure exerted is such as to burst the walls and throw out the seeds. It would not be of much advantage to a broom lush were its seeds to drop straight down from the branches; the new seedlings would at once enter into competition with the parent plant and they would starve each other. But by sending its progeny some little distance into the world the young plants enter into competition with other organisms and the chances of increase of the future generations of brooms are thus greatly increased. Mechanical devices like this are not very numerous, but that they are very effective is shown by the way in which both whin and broom succeed in spreading and in holding their own against all comers.

There is a common kind of balsam grown in many gardens in town-a reddish or purplish-green plant standing some three feet or so in height and bearing peculiarly pouched white or pink flowers. Its seed-pods, which look like elongated buds, are very curious. If you take hold of them between the finger and thumb when they are ripe they immediately squirm in a most remarkable manner. I have seen a lady drop one under the impression that it 
contained some little animal. If quite ripe these pods will crack into four ribbon-like valves and by the rapidity with which they twist will throw out their seeds. All the balsams have this property, and on account of it the genus has received the suggestive technical name of Impatiens. The yellow balsam of the Welsh and Northumbrian hills in Britain is called noli me tangere_-"let no one touch me,"-from this irritability of the seed pods. In Britain two other species have been introduced and are rapidly spreading, and it is noticeable that the kind I refer to as found here is inclined to be a weed in all the gardens in which it occurs.

The only other plant common in our gardens which throws its seeds away from it is the Oxalis. I do not profess to know whether this is the true shamrock or not, but the plant often goes by that name. In this it is not the seed-pod which bursts, but a peculiar fleshy network or skin in which the seed is enveloped, and which ruptures with force sufficient to throw its contents some feet away. The most curious example of this property possessed by some plants of scattering their own seeds was met with by me some years ago in the Melbourne Botanical Gardens. Seeing a plant with gourd-like fruit, I touched one with the point of my stick and was at once saluted with a slight report and a volley of pulp and seeds. The plant was the curious squirting cucumber of Southern Europe. It might be asked, If such devices are so valuable to the plants possessing them in enabling them to disperse their seeds, how are we to explain the case of plants, like chickweed and other common weeds of cultivation, which merely allow their seeds to fall out on the ground round and under them? It will generally be found in such cases that the plants depend for their success in the struggle for existence on their ability to crowd out or to smother their opponents, and they are usually furnished with great numbers of rapidly germinating and maturing seeds. It must further be borne in mind that a device which may be advantageous in one plant or group of plants may be apparently superseded by some different device in other 
plants. The modes by which any particular result is reached are infinite.

It is very delightful in the early part of the season to hear the blackbirds and thrushes piping out their mellow songs, but we are often inclined to think we pay too dearly for our music. When we find our fruit being eaten up, we are apt to forget any good the feathered musicians do. It is due to the habit of fruit eating on the part of these and other birds that our 'Town Belt is now becoming over-run with elder-berry bushes. Just as many flowers produce bright petals, fragrance, nectar, or superabundance of pollen, to attract insects to them and thus bring about cross-fertilisation and production of fine seed, so many plants ripen their seeds inside of a mass of succulent pulp, in order that birds may thus be tempted to swallow them. The production of a certain quantity of attractive succulence is the price the plants pay to get their seeds scattered. For the birds swallow them and pass them through their alimentary canal undigested. Sometimes the whole of the seed-vessel becomes pulpy, as in the gooseberry or poro-poro* (commonly called bulli-bulli), and in these cases the seeds have a sufficiently hard shell to resist the digestive juices of the bird's stomach; or the inner portion of the seed-vessel becomes stony or woody, as in the plum or cherry, and as in our native Coprosmas (Stinkwood, etc.), and this equally resists digestion. Fruiteating birds do not swallow stones, as graminivorous birds do, otherwise they would grind up and destroy the seeds they eat. This device of a succulent pulp is arrived at in a great many different ways in different plants; but the object remains the same in all. In the apple, pear, quince, hawthorlu, and mountain ash, it is the outer portion of the tube of the flower which becomes succulent, and the smaller of these fruits are particular favourites with the birds. Indeed it is noticeable now that blackbirds and thrushes seldom leave the fruit of the rowan or mountain ash alone once it colours, and those who grow these trees for the sake of their ornamental fruit are annually disappointed.

* Solanum aviculare. 
The larger fruits are of course not swallowed, but they are frequently carried away to some quiet place to be eaten, the fleshy portion alone being taken and the stone or seed left. In this way many people lose valuable fruit, as the thrushes will come early in the morning and carry off apricots or peaches from the walls of dwelling-houses.

'The number and variety of native plants with succulent fruits is very considerable, and it is curious in how many different families of plants the device is adopted. It arises no doubt from the fact that in a country largely bushcovered and destitute of mammalia, birds would be the only available living agents which could be utilised. I find that out of some 38 genera of trees and shrubs represented in the bush in and around Dunedin no less than 23 have distinctly succulent and attractive fruit, while even of the remaining 15 some are more or less succulent and fleshy, even though not particularly attractive. Among these 23 genera the devices for attraction are numerous. The most striking perhaps are found in the Pine trees belonging to the genus Podocarpus (Black Pine or Matai,* Miro, $\dagger$ and 'Totara $\ddagger$ ), where the so-called fruit is really only a brightly-coloured swollen stalk on the top of which one or more small naked seeds are perched. These false berries are greedily eaten by many birds, but it has to be remembered that by settlement and destruction of bush the pigeons and kakas which fed so largely on these fruits have been driven away from the neighbourhood of our towns. In tutu (Coriaria) the petals, which have lost their function as petals and are small, green, and unattractive in the flower, grow after flowering and ultimately swell up full of purple juice, and enclose the small dry fruit within them. It is curiously corroborative of the feeble digestive action of the birds' stomachs that they can eat, and no doubt swallow, the seeds of tutu, which are the most poisonous portion of these very poisonous plants, without any injury. I have not myself seen birds eating the fruit of tutu-probably many settlers have-but the

$$
\text { * P. spicata. } \quad+P \text {. ferruginea. } \quad \ddagger P \text {. Totara. }
$$


extreme beauty and rich succulence of the fruit, especially in the inland and western parts of Otago, and the abundance and great range of the species, point to their free use as food by birds. The common Muhlenbeckia, a pale green climber found on the edge of the bush throughout the Town Belt, has much the same device of succulent floral envelopes, but this plant belongs to the same family as the dock, while the snowberry,* possessing the same style of fruit, is a beath.

A pretty example of this development of succulent fruit is to be seen commonly in the Town Belt just now in the hina-hina (Melicytus ramifloms). This plant belongs to the same family as the violet and pansy, and if the unripe fruit of these be taken and cut across, each will be found to have a hollow ovary with three rows of seeds fastened on the walls. Yet, in accordance with their different modes of distribution, they ripen in a different manner ; in the violets the walls become dry and split open by three valves, but the hina-hina depends on some bird to distribute its seeds, so its seed-vessel does not open but becomes fleshy. The branches are just now covered with these blue-black or purplish berries, which are very pretty to look at and are no doubt sufficiently attractive to birds to serve as food to them; yet their succulence is almost a negligeable quantity. It is a fact that, just as the Maoris seem to have been content with, or at least dependent on, vegetable products of a very inferior quality for food, so the birds of these islands had in most cases to content themselves with very poor stuff in the way of fruit. Even where genera are alike in different lands, as in the case of the genus Rubus, the New Zealand species compare very unfavourably with others. The European and American blackberries and raspberries are very different from the fruit of the native bramble. Indeed, all our native fruits lack sugar.

Birds are not the only carriers of seeds; animals which have fur or hair serve to convey other species about. Naturally one would expect in a country which had no

* Gaullheria antifoda. 
native mammals (except bats, etc.), that such devices would be almost unknown among the plants. It is accordingly a curious fact that there is not a single endemic species-that is, a species confined to these islands-which is dependent on this mode of distribution, except, perhaps, one or two feeble sedges. The example which naturally suggests itself is the familiar piri-piri-usually mispronounced bid-a-bid-(Accena sanguisorbce), so much appreciated by picnickers. This plant is a degenerated representative of the Rose family, and its device consists in having its calyx-lobes developed into four spines, which, a little before the fruit matures produce at their tip a small spreading barb. It is a most perfect anchor, and the way in which it can attach itself to cloth would be very interesting if it were not so irritating. Now it is noticeable that of the five* species which occur in these islands only two have the barbs - of these the one commonly found here is equally abundant in Tasmania and Australia. There it probably developed its barbs to catch the fur of kangaroos, wombats, and similar animals, and was perhaps introduced into New Zealand by means of birds. The other species, which occurs more commonly in the upland districts of this island, is evidently a form of great antiquity, as it ranges away to Tierra del Fuego and the Falkland Islands. Thus the two species which have a wide distribution outside of New Zealand have the barbs, while the other three, which appear to have originated in these islands and are confined to them, have lost the barbs; in one of them even the calyx spines are scarcely developed. Thus a structure which was functionless because useless, where there was nothing to catch on to, has evidently tended to disappear.

* Cheeseman describes six species of Accena, but of these A. Nove Zealandice is so closely allied to $A$. sanguisorbe that it hardly deserves specific rank. 


\section{Chapter VI.-April.}

I.

A UTUNN brings with it the fall of the leaf in deciduous A trees, and by the end of April many of the introduced and a few of the native species will be bare or nearly so. Oaks and some beech trees may carry their dead leaves into spring, but most of them will be on the ground by the beginning of winter. Reference has already been made to the relation which exists between deciduous leaves and snowfall, and to the changes which have led evergreen forms like Fuchsias and ribbonwoods to become more or less deciduous in the southern and the mountainous parts of New Zealand.

The fall of the leaf is a phenomenon so common and so familiar that we seldom stop to investigate it, and yet it is full of interest and instruction. I have before me as I wite a number of branchlets of various trees and shrubs; on some the leaves are turning yellow and a few have already fallen; others are evergreen. There is nothing in an external view to suggest any difference, nor is it possible to detect any by means of a hand-lens, even if a section is taken longitudinally through the base of a leaf-stalk. But if such a section be made thin enough, and be treated with a little iodine solution, it frequently reveals under the microscope the mechanism by which the leaf falls. A thin plate of cells is formed right across the base of the leaf-stalk, and it is at this plate that the severance takes place. This plate begins to develop in summer, and as the season advances one layer of the cells hreaks down into a thin mucilage, while others lower down have their walls converted into cork. It is at the mucilage layer that the dead leaf separates, while the cork cells, being impervious to air and moisture, form a protective covering for the exposed surface. Internal pressure, caused apparently by absorption of water into 
the cells of the dividing layer, causes the fibrous tissue of the leaf-stalk to be torn, and thus the leaf is quietly severed and thrust away from its connection, to drop by its own weight. Sometimes frost on a still night causes a rapid fall of leaves on account of the freezing and consequent expansion of the fluid in the separating layer.

Before the leaf falls, its colouring matter, the chlorophyll which gires it its green colour, has begun to alter in chemical composition, turning at the same time yellow, red, or brown. We do not know what the exact change is, but no doubt there is a withdrawal from the leaf of soluble materials, which are either stored up elsewhere for future use or are converted into new tissue. Thus, if you look at the branches of deciduous trees you will find that next season's buds are already well developed, those on some twigs of beech in front of me are already more than half an inch in length. Then all organisms must have some means of getting rid of dead and waste matters. Animal organisms excrete and throw off these by a variety of glands, but in the vegetable kingdom organs which exist for the express purpose of getting rid of waste matters are either unknown or are very rare. But in the case of all the higher plan/s the leaves serve as vehicles for the disposal of effete matter. Before they fall normally their protoplasm and starch are absorbed back into the main tissues of the plant, while deleterions matter's like oxalic acid are stored up in the leaves along with spare lime and potash.

This separation of leaves when their work is done serves more purposes than one. If they remained on they would subject the plant to strains during gales and high wind at a time when the new rootlets are beginning to develop, and when the branches are comparatively tense with formative material. Only deciduous-leaved plants with extremely tough stems, like oaks, seem able to hold the leaves when the latter are dead and functionless. Further, by the separation quietly of the dead leaves, these fall all round the parent plant instead of being blown to a distance, and thus they help to enrich the surface soil. Then worms 
carry the decaying vegetable matter into the soil, where it tends still further to decompose the mineral matters of which the soil is mainly composed.

The withdrawal of the utilisable food materials present in the leaf is usually associated with a marked change of colour, the green being replaced by tints of yellow, brown, and red. These alterations of colour are not conspicuously marked in the New Zealand flora, not are they as a general rule very noticeable in evergreen plants. But the mountain ribbonwood turus yellow, the Fuchsia purplish or brown, while the large leaves of the rangiora (Brachyglottis Rangior $($ ) become beautifully veined with red and purple. It is in the nortl temperate zone, and especially among the North American and Japanese plants, that the brilliant autumn tints are so conspicuous. There is no reason to believe that these colours are always specially developed at the approach of autumn. The pigments which cause them may be and possibly are normally present in the living plant, most of them perhaps hardly distinguishable in composition from the green colouring matter of the leaves, but all of them nasked by the preponderance of the green chlorophyll. In all the young cells of growing plants there occur minute colourless bodies which are technically known as chloroplasts - carriers, as it were, of colouring nuatter, so called because under suitable conditions they develop into coloured bodies. What these conditions are we only know in part. Sunlight seems to be necessary, though some plants can produce their pigment in dense shade, as happens in many ferns and mosses, while others produce it in their seeds. But light does not always produce a green colour, for we know that many plants show natural modifications of red, yellow, brown, and even white, a fact which horticulturists take advantage of to cultivate silver, golden, and variegated races of foliage plants. In flowers, also, by the unconscious selective action of countless generations of insects, the bright hues which so charm our eyes have been developed. The materials were there, but they required selective action to cause then to so preponderate as to produce the prevalent colours of the various flowers. 
When the leaves fall there are many agencies ready to hurry them to that decay by which their constituents are once more returned to the soil in a condition fit to be used as food by the higher types of plants. Countless hosts of bacteria and numerous species of fungi, especially of the minute forms known as moulds, hasten on this work. They decompose the highly-complicated substances of which the plant tissues are composed into much simpler materials, which are capable of absorption by living plants, and thus the cycle of chemical change goes on unceasingly.

The ground, too, under and among the dead leaves, is full of animal life, much of which is concerned directly or indirectly with the same process. Reference has already been made to the action of worms in carrying vegetable matter to considerable depths into the soil, but there is an equally important work which they do in leaving their castings, composed almost entirely of earth, on the surface of the ground near their burrows. Millipedes, larva of many insects, terrestrial crustacea, snails, and other animals help in this work. The concealed (cryptozoic) fauna of New Zealand was investigated by Professor Dendy, formerly of Christchurch, and it is a very interesting study. Special groups of it have been worked up by other specialists; for example, Professor Chilton, now of Canterbury College, has made a study of the terrestrial crustacea, the woodlice and their allies, so that a good deal is now known about these little creatures. But just as in the more visible world of animal life there are carnivorous as well as herbivorous creatures, and "big fleas have little fleas to bite 'em," so in this hidden life on the surface of the soil there are numerous forms of animals which prey on the others. Spiders, centipedes (popularly known as "Jenny hundred-feet"), beetles, and many carnivorous larvæ of other insects, planarians or flat worms, and perhaps also some of these crustaceans already referred to, are all feeders on flesh-dead or alive.

One of the most remarkable of these " hidden " animals, which may be found among decayed wood in the bush or in localities where bush has formerly occurred, is known 
as Peripatus. It is a ereature of very primitive type of structure, not an insect, though somewhat like one in general appearance, but a form of perhaps greater antiquity than any insect type. It resembles a velvety caterpillar, of a brown or purplish colour, but differs in possessing about a score of pairs of feet, and carries a pair of short stont antennre in front of the head. It is a very sluggishlooking little animal during the day-time, but moves about more freely in the dark. When irritated it ejects from glands in the front part of the body small jets of an extremely viseid material, so that if any fly, spider, or other small animal were to attack it, the aggressor would be immediately glued up by threads of this sticky substance. While it can thus defend itself, it is not an ascertained fact whether the secretion is for defence purposes or for catching prey. I have often kept these little creatures in confinement and could make them fire off their artillery by a little judicious poking with a twig. If, however, a fly was held to one of them, a discharge of secretion was immediately poured on it. Later on, when the victim was dead or motionless from the glueing action of the viscid substance, the Peripatus returned at its leisure and ate it up. I found that when well supplied with flies these animals increased in my vivaria, but if they were forgotten for a time their numbers diminished mysteriously, - the big ones evidently having absorbed the little ones. This phenomenon is not, of course, confined to Peripatus; it is very common among the lower animals, fishes being great sinners in this respect; and it is liable to occur even among the higher animals when they are kept in confinement.

April is thus seen to furnish much of interest to the naturalist. Vegetation is largely in a state of rest, but the animal world is still vigorous, and has not yet been lulled to dorinancy or perpetual sleep by the cold of winter.

II.

In referring recently to those plants to be found in our gardens and growing by the waysides which throw their 
seeds to some distance from them, I omitted to notice a very common one, and one which is very familiar to many horticulturists, though very few know it by name. The plant I mean is a small bitter-cress (Cardamine hirsuta), which is a most tronblesome weed, not only in permanent garden beds, but also in flower pots. It is such a typical weed, such an excellently good example of what a weed really is, that a short notice of it may not be out of place here.

We often use the word "weed" in its application to human beings, to designate a poor miserable creature, of feeble physical, mental, and moral development. In one sense the term is right. Such a being is a survival, not of the fittest, but of the unfit; and such a survival is rendered possible only by the artificial conditions under which most human beings live. Similarly we speak of weeds among horses, but we may be quite sure that there are no weeds among wild horses. Weeds cannot exist in a state of nature; they are only an ontcome of human activity, paradoxical as such a statement may seem.

So keen and fierce is the competition among all living organisms that any individual not thoroughly equipped for the struggle, or which from any cause is unduly handicapped in the race for life, tends to be rigidly suppressed. But man, with his sentient faculties, dislocates the natural conditions to a greater or less extent, bringing into the problems new factors, whose exact influence it appears impossible to estimate.

'Thus, in the question before us now, the very process of clearing the ground of its vegetation, of breaking the surface of the soil and keeping it stirred, has furnished during the ages a new factor in plant growth. There has been evolved a race of plants, belonging to many and different families, which have acquired the power of growing under the new artificial conditions, and which consequently we know as weeds of cultivation. However diverse their characters may be they agree in one point, namely, that they are able to take advantage quickly of these conditions and to thrive under them. Thus these 
plants really represent the survival of the fittest in this struggle against man and those forms which he cultivates.

Our little bitter-cress is one of these specially-developed plants, and it is noteworthy that part of its adaptation consists in having its flowers degraded so as to be capable of self-fertilisation, and thus independent of insects. In poor soil it forms little rosettes of leaves lying close to the ground, the whole plant being not more than from half to one inch in diameter. In better soils it reaches as much as six inches in height, but it is always a small plant, with numerous small leaflets, which have a taste and smell like that of cress. The flowers are produced on short stalks, and are so minute as to be frequently unnoticeable. Usually the first indication they give of their existence is the development of their seed-pods. The common form of flower in a crucifer, as seen in the turnip, cabbage, or honesty, has four green sepals, four coloured petals, six stamens, and a two-celled ovary. In the much retrograded form of Cardumine there are four sepals and an ovary, but the petals are either totally wanting or are very much reduced, while only one or two stamens are produced. As the flower is self-fertilised there is no need for attractive petals, while a single stamen probably supplies more than sufficient pollen to fertilise all the ovules in the ovary. However prolific and even wasteful nature may sometimes seem to us to be-and she does seem to be lavishly so in many cases which we do not fully understand - we yet find a principle of the strictest economy running through all her developments. Unnecessary organs tend always to become atrophied or to disappear, and hence we find in a flower which does not need to open in order to be fertilised, that four or five of the normal six stamens are superfluous and therefore are not developed.

The seed-pods ripen very rapidly, a few days is all they need. Then if the plant be taken hold of to pull it out of the ground, snap go the small pods like miniature popguns, and a shower of little seeds is heard to fall all round. Truly it is an aggravating little weed. You have a flower border beautifully clean, and flatter yourself that it will not need 
to be touched for months, and lo! in three weeks it has grown a small crop of these weeds, which repay your attempts to pull them out by scattering a fresh crop of seeds.

Cardamine hirsuta is both indigenous and introduced. In this respect it resembles the dandelion, sow-thistle, and a few other plants. In all these cases, however, the plant which we meet with in our gardens is the introducer form, which is just as aggressive in its own way as is the European settler when compared with the indigenous Maori. The uative Cardamine occurs conmonly in the bush-covered parts of the Town Belt; it is a much more slender plant than the introduced form, and has always four white petals and six stamens. It has not developed the bad habits of its European relative.

\section{III.}

While writing the foregoing lines I have been sitting in the shade (for the morning is oppressively warm), and at intervals watching the insects which visit the masses of French and African marigolds and single dahlias which are in flower a few yards away. The commonest insect just now is a drone fly (Eristalis tenax).* It is very like a thick-bodied hive bee in appearance, but is easily recognised by its two wings, whereas the Bee lias four. It is also a much more deliberate insect, going slowly over the flower heads as if enjoying itself in a leisurely manner. Its curious rat-tailed larva is very well known; it occurs in stagnant water, in ditches and pools, in the earlier part of the season. The honey bees have taken advantage of these warm days to come out in considerable numbers. They always mean business, and go about the flowers as if they were in a hurry. There is no such thing as cultured leisure among bees; they work for work's sake, and take life very seriously.

Every now and then a humble bee comes bustling along. These insects particularly affect the dahlia flowers, but seldom visit the marigolds. At this season of the year it is

* Introduced from Britain. 
chiefly the small males which are out; their term of life is short, as all will die with the advent of cold weather, and only the queens will be left to rear next year's brood. But the insect which is most in evidence during this hot weather is the Red Admiral butterfly.* One comes sailing along now, with that peculiar jerky hovering flight which is so characteristic of this fine group of butterflies. It lights upon a flower head, folds up its gorgeously coloured wings so as to expose the large eye-spots on the under side, while it moves rather awkwardly about, as if its body and wings were too heavy for its slender legs. I have been watching one now for the space of five minutes, and have been surprised at the number of blossoms it has visited in that short space of time. It has not only tried several marigolds and dahlias, displacing a humble bee from one of the latter, but has three different times visited the same bunch of stock flowers. This is a thing which a bee seldom does. It visits a flower once and tries the nectary, but seldom goes back to it again. Bees work with ordered purpose and intelligence as compared with any other kind of nectar-gathering insect.

The Red Admiral, as I have called this butterfly, though it is not the same as the insect of that name so well known to English lepidopterists, is said to live in the larval stage only on the nettle. In face of the abundance of the mature insects and the scarcity of nettles, this is a statement requiring verification, and it may be that it is not confined to this food plant, but has merely not been observed on others. The caterpillar joins several leaves together to make its retreat, and is thus very easily overlooked. But it must be much more common than is believed, and it would be an interesting experiment to try rearing some on different food plants.

\section{IV.}

As the days shorten and the sun gets lower in the north, the ground begins to assume its winter dampness, and the falling leaves and decaying vegetation give a deadened 
aspect to all nature. 'This is particularly noticeable in the neighbourhood of Dunedin, where the hills and vales, with their still remaining stretches of woodland, form so many shady spots which the sun seldom touches in the wintel months. Our hills too, so high and so near the sea, cause a much greater condensation of moisture than is common either immediately north or south, so that though the rainfall may not be excessive, there is a great prevalence of mist, especially when the wind is from the north-east. Though the actual amount of rain which falls in Dunedin is smaller than that recorded from many other centres-for example, from Auckland or Wellington-yet the atmosphere here is so often at saturation point that dampness may be termed one of its chief characteristics.

In writing recently of the modes of distribution of fruits and seeds, a subject which naturally suggests itself at this season of the year, I made mention of the piri-piri (Accena) as a curious example of a plant dependent on passing animals for the scattering of the fruit (p. 74). I pointed out the fact that while the species with a wide distribution outside of New Zealand had barbed fruits, the indigenous forms had lost these devices. A parallel case is furnished by certain sedges belonging to the genus Uncinia. These grass-like plants, furnished like many other "cutting grasses" with scabrid edges to their leaves, are found along the fringe and in the more open parts of the bush, as well as in damp sedgy ground. They are, for instance, abundant about the shooting range at Pelichet Bay. When the fruiting spikes are ripe they are furnished with long bristles carrying a stroug barb at the point-one to each fruit-and these catch on to any passing animal. The explanation of this barbed structure in a New Zealand plant where there are no indigenous mammalia is the same as that for piri-piri. Uncinia is a genus which ranges away to South America on the one hand and to Australia and South Africa on the other. This wide range points to a considerable antiquity for the genus, and its mode of distribution has evidently been developed in lands where mammals were to be found. Of course both piri-piri and 
Trcinia might be distributed by ground birds, but the fact already stated as to the tendency in the former plants to disappearance of the barbs shows that the method is not very effective.

Another very common and effective mode of seeddistribution has been much in evidence during windy weather recently. Many plants develop their fruits or seeds (the terms in many cases are used somewhat indiscriminately) in such a way as to be caught and borne along by the wind. Willows, some poplars, willow-herbs (Epilobium), and that common white-flowered bush climber Parsonsia, have small seeds furnished with tufts of hair, so that when the seed vessels open and set their contents free the little seeds float away on the slightest breeze, each borne on its own little parachute. In the Clematis each fruit has a long feathery style acting in the same way. An almost identical device oecurs in the fruit of the great order of Composites, an order containing some 10,000 or 12,000 species of plants, in a great number of which (exemplified by thistles, dandelion, groundsel, etc.) the tube of the calyx develops into a crown of hairs or bristles - the so-called pappus - by means of which the fruit is carried on the wind. It is in great part owing to this exceptionally good mode of scattering their seeds that Composites are not only the most numerously represented, but also the most widely distributed, of all orders of flowering plants. Their nearest allies, the scabious or pincushion flowers and the valerians, are much more limited in their range.

Into the gutter's and sides of footpaths, where dust loves to congregate, the wind has during the last few weeks swept many of the winged fruits of the maples and ash trees. The latter tree has a single nut bearing a long flat expansion of its outer covering which acts like the sail of a windmill, while maples have usually twin nuts with spreading sails. On a breezy day they go whirling along in the air till they come to rest in some damp or sheltered spot, where they promptly commence to grow. Natives as they are of Northern Europe, where the winters are 
very cold, there is nothing in our mild winter season to stop their immediate development. Pick up a maple fruit and take off the onter covering so as to expose the seed, and you will be surprised to find how far advanced the future plant is. Its first pair of leaves are lying there all green (though hidden from the light) and ready for action, while its root is well developed.

The different extent to which the rudimentary plants found inside of seeds are developed is as interesting and as diverse as the varying degrees of development shown in young birds when hatched out of the egg. It is well known that chickens can run about and peck very soon after they come out of the shell, and that some gallinaceous birds, such as grouse and partridges, are even still more advanced. Those who have had some acquaintance with country life in the old land know that if a grouse is flushed when her covey is hatching the old bird will fly off with a loud alarm cry, at sound of which the chicks run off to cover in all directions, some of them perhaps carrying part of their shells on their backs, because they have not had time to get rid of their former domicile.

On the other hand, what a helpless little creature a newly hatched sparrow or a pigeon squab is, and how utterly dependent it is for weeks on the care of the parent birds as it slowly develops its limbs and feathers while still in the nest.

Somewhat similar is it with seeds. Some are ready to spring into active life-work at once, others take weeks, months, or even years, to develop their embryos into plants able to feed themselves. The seed of a cress plant, for instance, has its first root and pair of young seed leaves well developed as soon as it is ripe, and if sown in damp warm weather hoth of these organs are able to assume their functions and to support the new plant in the course of a few lays. But if you split open a cocoa-nut you will find the other type. At one end of the nut-near the three finger marks - is a small rudimentary plant which will take months to force its way ont of its shell, and which will require to absorb nearly all the food 
material stored up inside the nut before its root and stem are sufficiently matured to perfor'm their full functions.

Just as there are among birds whole families in which the young are well advanced when hatched out of the egg, and other's in which they are in a very imperfectly formed condition, so there are families of plants with very fully developed embryos in their seeds, and others in which the embryo is in a very rudimentary condition and has a store of nutritive material laid up alongside of or round it, and which it must use up before it is ready to begin life on its own account.

In both cases the development of the young has no direct relation to the ultinuate development of the adult form. Thus some of the most highly differentiated birds hatch out their young in a very imperfect condition, whilst those which are so very wide-awake as chickens are not characterised by great intelligence in the adult state. The seeds of plants belonging to the Cruciferæ, an order of plants with rather simple flowers, always have the embryo in a well advanced condition, while the highly developed family of orchids-most wonderful, and in respect of the flowers the most highly specialised of flowering plants - have their enbryos in the most elementary condition known.

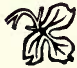




\section{Chapter VII.--May.}

TENNYSON sings of

\section{I.}

"Autumn laying here and there

A fiery finger on the leaves."

How appropriate the figure has been this season, when the fiery finger has been slow in coming and has left its mark so long. Wherever the trees, so familiar and so dear to many of us in the old northern home, have been planted in this new land, the gold and russet tints have charmed the eye for a month past. It needs a sharp frost or a succession of frosts to drop the leares quickly, but so faron the hills at least-there has been no frost, except a slight touch yesterday morning. There has been, what is less bearable than frost, a prevalence of cloudy weather with bitterly cold sontherly wind, but this does not check regetation so effectually as a drop of the temperature below freezing point. My dahlias, though ragged, are still quite green, and indeed are not quite done flowering, and few things show the frost quicker than dahlias. This morning their top leaves are blackened a little.

Our earliest tree-planters here had a fancy for species of Eucalyptus, especially the blue gum (E. globulus), but this tree is not much planted now, though the timber, even of young specimens, can be more readily ntilised than is the case with many other trees. Then followed the age of sombre coniferons trees, when Pinus insignis and Cupressus macrocurpa were the universal favourites. These trees have their place, and the latter, though often short-lived, is a capital plant for a breakwind, as well as a handsome tree when growing isolated. But fortunately the taste for deciduous trees is spreading, and it is these which at this time of year brighten a woodland landscape with their varied tints. There are some fine clumps of these trees in various parts of the Town Belt, and in the gardens both of town and suburbs, and these have been very beautiful of late. 
Some trees lose their leaves without much previous change of tint. My walnut trees are still green below, but their upper branches are already bare, and apples, pears, and plums similarly show little change of colour. The leaves of horse chestnut and of the oak turn brown before they drop, and the latter keeps its foliage for a very long time. The leaves of maples and poplars, "turning yellow, fall and float adown the air," and the elms become nearly golden, while the birch, beech, and chestnut are reddish or even like old gold in the glory of their hues. Down our road we have watched the rowan fading almost to crimson, while a favourite dome-shaped lime tree has turned its foliage here and there to yellow.

The fall of the leaf at the approach of winter is a phenomenon alnost confined to trees of the northern hemisphere, and appears to be associated with the recurrence in the vast land areas of the north of glacial epochs, and with the modifications which plants of that hemisphere have acquired to enable them to stand the severe alternations of temperature to which they are subjected. I do not refer so much to the British Islands, where the climatic conditions are modified and tend to be equalised by the Gulf Stream, but to the great continental masses of Asia and Europe and of North America. For instance, in latitude $53^{\circ} \mathrm{N}$., which passes through the middle of England, a maximum temperature of $90^{\circ} \mathrm{F}$. is rarely reached there, while the minimum seldom touches $0^{\circ} \mathrm{F}$. In the same latitude in North Anerica, a summer heat of $90^{\circ} \mathrm{F}$. is common, while in winter $50^{\circ}$ (or $82^{\circ}$ of frost) is reached regularly. Similar conditions prevail in Russia and Siberia. It is apparent that plants which are to live through such severe winter cold nuust become dormant for a portion of each year. The vital functions are almost arrested for a time.

The leaves of trees are not only the principal feeding organs of the plants, but by the evaporation of water from their surfaces they canse a continuous flow of sap to ascend from the roots through the stems and branches. But the less water there is in a plant which is to be subjected to a 
temperature far below the freezing point of water, the safer it will be for the tissues of the plants, and this is probably one reason why the leaves are discarded before winter.

Another reason is that were plants to retain their leaves they would carry more or less snow, and if this were moist and fell heavily, as is often the case at the beginning of winter, much damage might result by the branches and stems being torn off or broken down. Looking round our shrubberies and plantations we might think that this statement was inaccurate, in view of the many evergreens which we see there. But it must be remenbered that most of our evergreens are not natives of cold climates, but have been gathered together from warmer regions, and often have a hard time of it in a sharp winter. An examination of the plants native to or at least growing wild in Britain shows this. There are in the British Isles about fifty species of indigenous trees and shrubs, exclusive of small forms like heaths, broom, etc. Of these only nine are evergreen-Barberry, Holly, Spindle-tree, Arbutus, Privet, Box, Scotch Fir, Juniper, and Yew-and their leaves are nearly all of a hard or at least a firm and dry consistence. The other forty-one are deciduous.

Those coniferous trees which grow in regions where the winter cold is very intense are either very stiff and rigid, and so do not carry snow, or their branches are given off at such an angle with their trunk that they have a downward sweep, and so yield to any load of snow which falls on them until they reach such a slope that their burden falls off. The Norway spruce is a familiar example. The only conifer I know of which does not fulfil these conditions is the larch, which drops its leaves at the approach of winter. This adjustment to varying conditions is well seen in two or three familiar genera of trees. Thus the deodar, or cedar of the Himalayas, grows in its native habitats on an elevation of 12,000 feet, and is subject every winter to heavy snowfalls. Its branches and foliage are flexible and yield at once to any weight of snow. The cedar of Lebanon and the allied cedar of the Atlas Mountains grow 
in warmer regions at a much lower elevation. When grown in Britain they are apt, as they grow old, to have their branches torn off by heavy snow falls, and it is a familiar fact that very old trees are usually supported by poles, as otherwise their large lorizontal rigid branches are frequently broken down.

Another instance of the same kind, familiar to us in Dunedin, is furnished by the southern genus Araucaria. A. excelsa, the Norfolk Island Pine, will hardly grow in the open so far south, though it thrives in all parts of the North Island. A. biduillii, the Bunga-Bunga of South Queensland, grows here very well, but is always liable to destruction or damage even by our light falls of snow. A beautiful specimen of this tree used to grow in front of the old manse at Knox Church, but one winter morning, when wather a heary fall of soft snow fell, with a southerly wind, the tree bent over towards the north, and the snow gathered on its branches and foliage till the trunk snapped over at the ground. A. imbricata, the so-called "Puzzle Monkey," is a native of Chili and Patagonia, where the winter is rather cold. One has only to look at the tree to see that snow could not hurt it, for it does not present a surface to carry any load. It is therefore beautifully adapted to its climatic conditions, and its hard foliage is not easily hurt by frost.

The fall of the leaf has been already referred to (see page 75) as occurring in the montl of April, but it is frequently deferred in mild seasons till late in the winter.

As the leaves fall, the thrushes, blackbirds, and hedgesparrows become shy about coming near the house, and it takes them some time to get accustomed to the bare branches and the consequent exposure to which their doings are now subject. But many native birds begin to come about which are not seen near houses in the summer months. Every day of late korimakos have been "tinkling out" their curious bell-like notes in the garden, a small tit has been investigating my operations among the flower beds, while even now a pair of grey warblers are flitting about in the foliage at my study window. The 
wax-eyes have been very abundant on the trees, searching up and down the branches for minute insects, and clearing out the blight. A correspondent records nearly the same birds as visiting his garden in Oamaru, with the very interesting addition of the wood-robin, a bird which he would gladly see increasing once more.

\section{II.}

Many visitors to and residents in Dunedin find fault with our climate as changeable and trying, and if one were here only to live an out-door life of sight-seeing and picnicing, the charge might be a true one. But for a fine working climate, in which one can be busy nearly all the year round with a ninimum of inconvenience, there could be no better climate, and its very changefulness may have its charms. Those who have lived in a dry tropical or sub-tropical region know how monotonous the very sunshine becomes, when the sky - day after day and month after month-is as burnished brass, and the eye aches for a patch of vivid green or the shadow of a great rock in a dry and thirsty land. They can appreciate the feelings of the Indian civilian on his way to the homeland, when the ressel in which he was voyaging up the English Channel ran into a thick wetting mist, as he rubbed his hands together and exclaimed, "Ah ! this is the weather for me; none of your _ blue skies!" But, indeed, our climate is not more changeable than some others with which it is often unfavourably compared. In all my experience of Dunedin weather I never experienced such sharp alterations of temperature as are common in Australia. What makes our changes here so noticeable is that the atmosphere is so frequently nearly saturated with water vapour that a fall in temperature of $10^{\circ}$ causes a great amount of condensation with formation of cloud. The occurrence of so much high and rugged ground in the immediate neighbourhood of Dunedin, while it is the cause of most of the romantic beauty of its surroundings, is also responsible for much of the moisture which characterises the atmosphere here. 
Ou climate is no doubt less sunny and more frequently wet than that of many another part of these favoured islands, but where could one see more prevalent greenery (outside of the Emerald 1sle), or finer cloud effects, and more beautiful alternations of light and shade on the hills, than we have enjoyed this last summer and autumn. Worls fail one in attempting to describe them.

One afternoon recently the skies and surrounding scenery seemed to be made up of impossible tints, which changed with the changing hours. The morning had been close and bright, with the suspicion of a warm north-west windsuch a day as we often have when the rain is pouring down on the West Coast-but as the day adranced leadencoloured clouds began to gather over the sky. Out at sea especially, where there were no hills to arrest the move ment of the south-westerly current which formed them, they rolled up thick and dark, causing the ocean to assume a deep and gloomy hue. The waters of the bay seemed also of a dark leaden colour, deeper than that of the ocean, while the town and the hills of the Peninsula stood out beautifully clear and distinct against the sombre background. Though the wind was blowing gently from the west, the dark clouds - which were at no great heightwere moving due south, while above them was moving the cold southerly current, which was really forming them from the moisture of the warmer air below. This is a common phenomenon in this part, the cold current which brings down our south-westerly rains often blowing over the top of the warmer surface air and ultimately dispersing it. It seemed as if some great atmospheric disturbance was approaching, and the heavens appeared to be gathering up their forces for an outburst. But the threatened storm never came, the outlines gradually became softer and the sky less lowering as the afternoon passed, and just shortly before the sun set behind the western hills his nearly level rays, breaking through an opening in the clouds, shot across the landscape, illuminating the hill-tops and pouring their mellowing light over the scene. It was a wonderful transformation, almost awful in its grandeur 
and superb beauty, but it was followed by a still more remarkable effect. When the sum had disappeared behind the high ground, the view to the north and east was simply marvellous. Pine Hill and Mount Cargill, North-East Valley and Signal Hill, were bathed in dark and sombre greens and greys, tinted apparently with lilac, against a background of almost indigo colour, which changed to deep violet as the light waned. Such clond effects would be classed as "impossible" on canvas, so startling were they in their contrasts. But they are not uncommon in our skies, and for all who have eyes to see they constitute one of the redeeming and beautifying features of our climate.

The question is often asked but seldom satisfactorily answered, How far does the cutting down and clearing away of bush affect the climate of a district? The popular idea is that it tends to make it drier. As far as any alteration in the rainfall is concerned this view is probably incorrect. The presence of large masses of high land in the neighbourhood of the sea probably modifies the meteorological conditions profoundly, but the removal of a few thousand acres of the surface vegetation can have very little effect on the condensation and precipitation of moisture in the district. But although the clearing of the bush may not affect the climate in general, it has remarkable and very serious local effects. Thus, in a sense, the people of Dunedin have shown extraordinary carelessness and neglect of prudential considerations in allowing any of the land in the catchment area of Ross's Creek to be alienated and the bush destroyed. Land covered with uncleared timber retains a great proportion of the moisture which falls upon it, and only parts with it slowly. It is not a difference of evaporation, for the probability almost certainly is that bush land evaporates water at a far greater rate per acre than is the case with cleared ground. It is more probable that the cause is due to the more spongy nature of the surface materials and the mechanical entanglements of roots and fallen vegetable debris. On cleared land the rain may, and probably does, fall as frequently and as heavily as before, but instead of being 
retained by the surface vegetation and slowly yielded up by the never-failing streams and rills, it now rushes off the sloping ground, carrying away the best of the soil into the valleys, and it does damage by its unrestrained vehemence. Hundreds of acres of land formerly covered with noble bush, the soakage from which formerly fed the northern reservoir, have been cleared dming the last two or three decades to make way for gxass fields, which cannot retain the moisture which the forest formerly held. And to make matters worse, houses have been erected in this catchment area and the drainage from these must find its way sooner or later into the town water supply. It is wonderful how complacently we accept all these conditions without so much as raising a finger to alter them. Give us a plague scare and we begin to bustle round and find out the objectionable features of our neighbonrs' back yards, but as to supplying the citizens with clean waterwhy, that is a totally different matter.

There is one kind of weather of a very trying and objectionable character which is experienced in all the open country on the east side of this island, from Southland to Marlborough, but which we get in a very mild form in Dumedin, thanks to the hilly euviromment. I refer to the hot nor'-westers, which in the Canterbury Plains are a perfect abomination, sweeping the very soil off the ploughed fields and parching the vegetation. The explanation of these hot winds is very simple and is familiar to every student of physical science, but is probably not popularly known.

When a north-westerly wind which has traversed the Tasman Sea reaches the West Coust of this island, saturated with moisture, it meets with a mountain range 6000 or more feet in height, against which it is forced and which it has to surmount. In accordance with a wellknown physical law, the energy required to raise the mass of air over these mountains causes a very considerable expenditure of heat, or, as we would otherwise express it, a fall in temperature, and this results in a great condensation of moisture. But when water vapour condenses a 
large amount of heat is liberated. The result is that the wind, in being forced up the mountain sides, pours out an immense quantity of rain on the West Coast, but reaches the summit of the ranges as warm as it was at the foot, this being due to the latent heat which has been parted with. Coming down the eastern slopes of the mountains it regains as much heat as it lost in consequence of being forced up the other side, and so pours down on the open country as a hot wind. This rise of temperature causes it to expand very considerably, so that what is a quiet mild rain-bearing wind at Hokitika, appears on the Canterbury Plains as a strong hot and parching blast, which shrivels vegetation and makes life generally rather disagreeable.

The phenomenon is common to many countries of similar conformation. Thus southerly winds from the Mediterranean, which cause heary precipitation on the Italian slopes of the Alps, blow over Southern Germany as hot dry scorching winds, exactly as our nor'-westers do. This wind is called the "föhn" in Germany and is very much disliked.

Though these winds "feel" heary-in Southland we used to notice that they seened to blow down on us at a considerable angle - they are really so expanded by heat as to lower the barometric pressure very considerably over a wide area. Therefore, after they have blown for a few hours they are almost invariably replaced by a colder heavier wind from the south-west. This inrush of cold wind usually lowers the temperature of the warmer air to below its saturation point and brings down a more or less prolonged rainfall. We had a very remarkable example of this only as recently as yesterday, when a warm northwest breeze, hardly felt in Dunedin as a wind at all, dropped the barometer very sharply, and into the area of low pressure so produced there came an inrush of cold southerly wind with a very heavy dorvnpour of rain. Of course such an explanation is only a very partial one, for we know little of the gigantic processes which are constantly at work in the atmosphere, but it gives a general idea of one at least of the potent causes of weather change. 
If we would only look at our changes of weather from a philosophic point of view, then even the bad ones might become bearable; but one must truly have a very philosophic temperament to be able to go out in the morning without top-coat and umbrella and get caught in a cold south-wester at noon without betraying any tendency to use unparliamentary expressions.

\section{III.}

The cold night-breaths of May set the seal on much of the year's growth, lulling many living things to quiescence and rest for the winter, and terminating the lives of many more. By this time most of the exuberant insect life of the summer has disappeared, the mature insects perishing, while the younger forms are either preserved as eggs, larvæ, or pupæ. Flowers too have nearly disappeared, and the rsthetic house dame is reduced well nigh to despair to find suitable floral decorations for her rooms. Everlastings and dried grasses, honesty and bulrushes-none of which may be shaken too freely lest they reveal the dust which clings so lovingly to them-are made to do duty instead of fresh flowers and autumn leaves. Deciduous trees and thorn hedges have now lost nearly all their foliage, and stand gaunt and bare to the winds of winter.

But May is not nearly our coldest month; it is often the finest month of the year as far as steady weather is concerned, and though there may perchance be a sprinkle of snow and occasional night frosts the ground is not yet chilled, and the days are frequently warm and bright. Nothing chills the earth like clear nights after rain. A layer of cloud or even mist-however thin-prevents radiation; but let the sky become intensely clear and the surface heat from the earth pours into space, greatly lowering the heat of the superficial layer of soil and of the strata of air immediately above it.

In the Northern Hemisphere many animals hybernate on the approach of winter, the squirrels, dormice, hedgehogs, and others, curling themselves up for a time of sleep 
-a most comfortable method of getting over the cold season. In New Zealand we have very few hybernating animals. The bats-which, alas, are now rare near the haunts of men-disappear for several months, to come out again when the warmth of spring returns. They mostly frequent caves or overhanging shelters in the bush, and are not uncommon too along the rocky seashores. Lizards also become torpid, and hide away till warmer days prevail, lying hidden under bark or dead timber, or in deep ferny hollows under boulders on the hillsides. Some insects remain late on the wing, the drone flies (Eristalis) being common flower visitants during May, while brilliant days tempt out some Red Admiral butterflies, which have probably crept into a cranny or nook not too far from the range of the sun's rays. Occasional humble bees also may be met with. By this time of the year, however, ouly mature queens survive, each being destined to found a new colony during the succeeding season.

But while the land thus becomes comparatively barren of life at the beginning of winter, the broad expanse of sea undergoes no such marked change, and the naturalist can find as much to interest him there in the month of May as in the height of summer. No doubt there are seasonal changes in the sea, but they are not so well marked as on the land, and far less is known about them. But we do know in a general way that vast migrations of living organisms take place; we can tell this by the abundance of certain species at certain periods. The industrious army of fishers-old and young-which lines the wharves knows something of this fact. Thus among fishes the barracouta is at times extremely common in the seas, and at other. times it has absolutely disappeared. A species of Octopus will appear in myriads in the harbour, and then for ten months of the year none are to be met with. One day a message comes to me that the harbour is full of young lobsters, and I go down to find an invasion of a peculiar red shrimp-like animal (technically known as Munida), which creeps on the rocks and stones of the beaches at low 
tide. But it is only found in such numbers for a limited period of the year. It is probably the same animal in another phase of its existence which appears in such numbers as to redden the waters when alive and to pollute the neighbourhood when dead, which is commonly known as "Whale Feed." But this, too, disappears for whole months. One might observe parenthetically that popular names are often utterly misleading; most things in the sea that are big enongh feed on this crustacean except whales. Up the coast in the summer months come countless shoals of pilchards and allied fishes of the herring family. How enormously profuse is life in the sea! These shouls are often miles long, and no figures can convey any impression of the numbers of individuals composing them. Whence do they come, and where do they go? Is it after the disengagement of the antarctic ice that the cold water of the Southern Ocean, setting up the East Coast, drives them onward? These are questions to which the answers have yet to be found. One can see the lines and trend of the shoals by the movement of the water, by the hordes of porpoises and fishes of prey which accompany them, and by the ever-moving army of birds which hover over them. There is thus continual movement in the ocean, and it is perhaps only becanse we know so little about these things that we are apt to think that the life is stationary.

But there is also a vast body of comparatively still life in the sea, - or rather one may put it this way, that certain forms are always to be found in certain localities, so that it wonld be possible to write a natural history of such an area, say, as Otago Harbour, and to affirm with perfect certainty that such and such species are to be found there all the year round. But even of such stationary forms it must be remembered that what has been affirmed of plants is equally true of them. There must be a period in the life of every organism when it is capable of being distributed. Flowering plants exhibit this in their seeds, ferns and allied plants in their spores. A barnacle fastened apparently all its life to a rock, and a coral zoophyte forming part of a reef, appear about as fixed in their. 
respective abodes as it is possible for living things to be ; yet at one time in the life of each it was a free floating organism. Thus crabs and crayfishes may be met with all the year round, but they don't live all their lives in the same restricted area. The young crayfish on emerging from its egg passes through many metamorphoses before it settles down in the guise of its parent to a life among the coastal rocks. In most of these stages it is a beautiful glass-like creature, of most delicate and fanciful structure, which floats on the top of the open sea and is easily taken in a surface net. So unlike crayfishes are these beautiful little creatures that the older naturalists described them as distinct species of a genus named Phyllosoma, for which they formed a special family.

Mention of these facts leads me to note that few people, even of those who take an interest in such things, know how much pleasure could be derived right through the year by keeping an aquarium, either a fresh or a salt water one. They could not keep larval crabs or crayfishes, but they could come to know the habits of many of the beautiful things which live in our ponds, streams, or coastal waters. Our young people have not yet learned to love and appreciate the beauties of Nature which lie around their homes. We hear a good deal about Nature studies in education, but most knowledge of her treasures is sought and inculcated at second hand in books. But no books can teach like the facts themselves, and only a little encouragement and observation are needed to get the interest aroused in the young.

The sea teems with life in May, as it does all the rest of the year. When the lover of Nature begins to find that much which interested him in the warmer months is now quite past, let him turn his attention for a time to the waters. I have no idea how many kinds of conspicuous living things can be met with in our harbour alone. I should be afraid even to hazard a guess for fear of arousing incredulity, but they must be extraordinarily numerous. First hand observation of these things is wanted. To lie in an anchored boat in any still clear 
and shallow water near weed-covered rocks is an education in itself, and one can learn more in this way than by much reading. And the rock pools on the coast are themselves microcosms, a whole world of life lying hidden in their nooks. And then special forms can be watched in small aquaria, and much knowledge thus be gained of their structure and habits. It takes some practice to keep an aquarium, but there is no real difficulty; it is only the matter of a few simple experiments and a little patience, and it becomes easy enough.

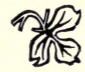




\section{Chapter VIII_-June.}

\section{I.}

TN June the year has not yet touched its deadest stage, because, though the sun reaches its furthest north point towards the end of the month, the mean temperature is not so low as that of July, and the ground has not become so cold and wet as it is in August. And although the naturalist who has been at all busy during the past season is more likely to find congenial occupation in the study of his collections by the fireside and by lamplight than in the field or roadside, yet there is much to be seen outside if one ouly knows where to look for it.

Nature is not dead, but only in part asleep, and in the leafless branches and under the ground there is the constant stirring of the life which is preparing to break forth in fresh vigour with the advent of spring. The Thrushes also sing on the tree tops, the native birds which come in towards cultivations and human habitations at the beginning of winter-korimakos, tom-tits, wax-eyes, and fantails-are still to be seen and heard about the bush and gardens, and the skylarks begin to soar heavenwards-all in anticipation of the nesting season which is soon to begin.

Butterflies are occasionally to be met with on bright days and in sumu nooks, and the first example which I met with of the pretty Vanessa itea was sent me from Saddle Hill one clear frosty June. Occasionally humble bees rashly venture out in search of food; of course these are only large queens, founders of the next season's colonies, and they have probably made their nests on sunny banks facing the north. But under bark and dead leaves, among the decayed and decaying rubbish of the bush, and buried in the ground, are numberless forms of insect life, much of it in the chrysalis stage preparing for the transformation which is to be consummated later. It is a time of transition.

Most plants have entered on their period of apparent 
rest in this month; the fruits have mostly disappeared, and the seeds are now committed to the soil to soften, swell, and get ready for their visible germination in the coming summer. But many of the succulent-fruited plants still carry their fruits, and this is the time to see them.

In mild seasons, following warm summers, I have occasionally found a few early flowers of fuchsia and kowhai in the month of June; but as a rule there are scarcely any flowers to be met with. On the other hand, non-flowering plants can be readily studied during the winter months. Ferns and mosses are in fine sporing coudition, and many of the liverworts throw up their capsules on slender white stalks, which open at the top like miniature crosses. But June is pre-eminently the month in which to look for curious fungi, many of which are very beautiful and interesting. One of the commonest is a large Boletus, ${ }^{*}$ a big brown toadstool, which frequently occurs under pine trees, and is, perhaps, an introduced species. It matures throughout the autumn and winter months, but seems to be more abundant during June than at any other time, to judge by entries in my note-books. As it becomes fully mature its upper skin acquires a slimy appearance, while its stalk and underside turn yellow. It is not an Agaric like a mushroom, which has its sporeorgans borne on plates or "gills," but the whole underside of its umbrella is made up of very numerous fine tubes, on the walls of which the spores are developed. They are probably set free by the liquifying of the tissues when they get washed away by the winter rains. This Boletus is edible - as indeed many toadstools are-and when properly cooked is not bad eating. If firm young specimens are taken, the thin upper skin peeled off, and the lower yellowish tube-bearing portion removed, the remainder is found to be white like a firm mushroom, having much the same smell, though not so good a flavour when cooked.

Another edible fungus to be found in June is named Clathms cibarius. I am not responsible for such names,

$$
\text { * Probably the introduced Boletus edulis. }
$$




\section{A NEW ZEALAND NATURALIST'S CALENDAR.}

so will not apologise for them, only pointing ont that if we are to speak of these plants specifically we must use the names which botanists have given theml. This is a subterranean fungus. something like the famous morels and truffles which fetch such a high price in Europe; and, being so, it is not possible to say beforehand where it may be looked for. In woods in the sonthwest of England, where truffles occur, I believe pigs are used to find them, the animals being driven away from the spots where they begin to root up the ground vigorously. But in France trained poodles are used for the same purpose. I have little doubt the Maoris ate this fungus, and perhaps knew how and where to look for it. At the edible stage it is like a large soft potato, the rough brownish skin corering a thick jelly-like mass; but when mature and ready to distribute its spores the inside is found to have developed a network of tubes as thick as one's little finger, and forming a large white basket-like frame several inches in diameter. This expands so much that it not only bursts open the enveloping skin, but throws up the soil, and thus becomes exposed. If a little of the brownish slime which occurs on the white tubes is examined nnder the microscope it is seen to consist of innumerable oblong spores.

Among the numerous other fungi to be looked for in June, two are deserving of special mention on account of their brilliant colour. Hygrophomes cyaneus is a bright sky-blue and rather rare species; but Aseroe mubra, which is not uncommon, is a red and very attractive form. It stands an inch or two off the ground, and opens ont like a fine red starfish, with several radiating arms. But handle it circumspectly, for its smell is most offensive, just like putrid carrion. Evidently it is meant to be visited by carrion flies, which, either themselves or by their maggots, help to disseminate the spores. But why should it develop its attractions in winter, and, indeed, why are so many fungi brightly and often delicately coloured? These are questions I cannot answer satisfactorily.

June corresponds roughly to December in the old 
Country, but, as everyone knows, the seasons are not marked here as they are there. The reason of this is not well known, nor is it apparent at first, though the following is perhaps a correct explanation. In the Norther'n Hemisphere the marks of a comparatively recent glacial period are stamped on all Nature-in erratic boulders and striated rocks, in lake basins and deposits of clay; many plants lose their leaves on the approach of winter, many others die down to the ground, others do not survive the winter at all; many animals also pass through a dormant or hybernating period. In these southern regions the conditions point to a somewhat milder climate in comparatively recent times. Few New Zealand trees are absolutely deciduous, though several become so in the South Island and in inland regions where the winter frosts are keen, very few die down to the ground, and only a few of the truly indigenous species are annuals. This may or may not be the correct explanation; it is the only one I can offer.

\section{II.}

On a bright forenoon one of the pleasantest of the many pleasant walks about Dunedin is across the peninsula from Anderson's Bay to Tomahawk Head. The road climbs along the landward end of the rising ground, and, turning sharply at the little God's Acre which looks out so quietly to the unremembering sea, leads down to the mouth of the lagoon. Most wanderers to the spot turn off to the right as soon as they reach the little bridge at the outlet of the lagoon and wend their way to the little beach which lies under the shelter of Lawyer's Head; but we will stay on the higher ground and turn our attention for a time to the left.

Tomahawk Lagoon is a prettily situated sheet of water, and when I first knew it was surrounded at its upper end with bush and scrub, and was fed by more than one perennial stream of clear water. Here we used to gather Lomaria vulcanica and other ferns which are not now to be got without rambling much further afield; the scrub was noted for the number of "stick insects" 
which could be gathered, and here the entomologist was always sure in the warmer months of the year to meet with good finds. But the destruction of the bush has dried up the streams, and the poaching of cattle round its margins has converted part of the lake into a boggy swamp. Now that the age of destruction has passed, an era of improvement might well be inaugurated by the surrounding proprietors, and with a little care and some judicious planting the spot might again be transformed into a place of beanty. The introduction of white and yellow water lilies, of the Yellow Flag (Iris pseud-acoms), and of the large yellow buttercup (Ramunculus lingua), would soon brighten its surface and edges with blossom. There are many pretty marsh plants of temperate regions which would thrive in its waters, and a sheet of water which at present is not particularly attractive, except at a distance, might be made a thing of beauty and hence a joy for ever.

I can remember that in very high tides the sea used to dispute the entrance up to and past the spot where the bridge now stands, but at present the whole lagoon is a sheet of fresh water right down to its mouth, and its level is not affected at all by the tide. But it cannot be very long since that it was a tidal inlet. A glance along the whole coast line of Otago from Kaitangata to the Waikouaiti River shows that the land has risen at no very distant date. At the present time we see going on in its various stages the process by which arms and inlets of the sea are being converted into flat plains.

Let us cross the bridge and, climbing on to one of the sandhills which hide the ocean from the road, sit down for a few minutes, and let our minds go back in inagination to the days of old, say, when the coast line stood twenty feet or thirty feet lower than it does to-day. A lake, probably of brackish water, at any rate at its middle portion, filled the lower part of the Taieri Plain, stretching away up to the foot of Maungatua and the lower Waipori Hills, away south beyond the present end of Lake Waihola, and communicating with the sea by the very 
narrow but deep outlet of the present river below Henley. The Kaikorai and Tomahawk Lagoons were salt- or brackish-water estuaries with the tide flowing into them; Hooper's Inlet, Wickliffe Bay, Purakanui Bay, Blueskin Bay, and Waikouaiti River were deeper estuaries, more like the present Otago Harbour, with sandbanks exposed at low water and bars at their mouths. Probably the dry sandy stretch at the bottom of Sandymount was a lagoon like that of Tomahawk now. Otago Harbour was a noble sheet of deep water in those days, its sandbanks of to-day "full five fathoms deep," and its waters lapping up to the foot of the hills in the North-East Valley and Woolhaugh. Lastly, Otago Peninsula was an island cut off from the mainland by one or more tidal channels from which wide stretches of sea water and of swampy lagoons extended up to the foot of the hills at Hillside, Caversham, and Forbury, and all the higher ground was bush-covered down to the water's edge. As the land slowly rose and the rains of successive centuries washed the soil from the hills to gradually fill up the shallower waters, littoral and marsh plants crept along the newly-formed shores, and gave lodgment to the sand which the troubled sea threw up, as it continues to do still, and which every on-shore wind blows landward. Thus by degrees the flats were won from the sea and the estuaries became lagoons. After all it does not require much imagination to realise what changes this gradual upheaval of the coast has brought about. The evidences of the fact are clear enough, so that he who runs may read.

Let us come down from our sandhill and ramble along the sides of the lagoon. We shall probably get our feet wet, but that is a matter of little importance in the pursuit of knowledge, and wet feet never hurt people as long as they keep moving. There are many things to look at and muse upon - things to the uninitiated eye which are perhaps more curious than beautiful, but which to the illuminati are full of meaning and beauty of their own.

The side of the lagoon bordering the road is made up with stones, and on and among these are to be found 
creeping certain little crustacea* about half an inch long resembling long wood-lice or slaters. Now it takes an enthusiast to appreciate and wax eloquent on the beauties of a wood-louse, and yet these creatures have been a source of great interest to many besides myself. I wonder if it is possible to communicate this interest to other's. It must be more than twenty years since Captain Hutton first drew my attention to the occurrence of these animals at Tomahawk Lagoon. I at once made an expedition to the spot, collected a number, and was delighted to find that they belonged to a genus of marine forms (Idotea), which was not previously known to have any fresh-water representatives. Idoteas are familiar enough in our harbour, and are often to be met with in abundance along the sea wall at the cement works. They are usually of a greenish colour, are an inch or two in length, and, owing to their numerous feet, have a "creepy" look that is very trying to some people's nerves. Some two or three years after the description of Idotea lacustris was published, Dr Coppinger, a surgeon on board of one of her Majesty's ships, collected a species of Idotea at Port Henry in the Straits of Magellan, and on examining his specimens at the British Museum it was found that they were identical with our Tomahawk species. More recently still, Dr Chilton met with the same creature at the mouth of the little stream which rums into Sawyers' Bay, and, following up the stream, he found that it was quite at home in the fresh water. This led him to follow up the little stream to its source, away up on Mihiwaka, and there, at an elevation of 1500 feet, our little Idoter was still to be found. One discovery leads on to another, and I was induced to search in other directions. So, furnishing my boys with tubes and a specimen for identification I got them on one of their excursions to search the streams on Flagstaff and Swampy Hill, and sure enough, from a height of 2000 feet, they brought me down my little friend. It is not a very common thing to find marine forms invading fresh 
waters, but exanıles can be found among many families; and our Idoted is a not uninteresting case. There is one point on which further information is wanted, and that is whether Dr Coppinger's specimens were found in fresh water or in the sea. If in the latter, then it is probable that our New Zealand forms have only recently acquired the fresh-water habitat. But if the species occurs in fresh water in Patagonia and Tierra del Fuego, then its occurrence in two such widely separate localities as New Zealand and South America becomes a much more interesting problem-one related to the distribution of the tutu, the gemus Fuchsia, and that of various other forms of vegetable and animal life.

The usual plants, mostly of the sedge and pond-weed families, which are to be found in all coastal lagoons, are net with abundantly in that at Tomahawk. Some of these are characterised as marking the border line between fresh and salt-water plants. While marine animals, as I have said, are to be found in several instances invading fresh water, it is very rare to find marine plants doing so. On the other hand, a few fresh water flowering plants appear to have acquired the power of growing first in the brackish water of estuaries and then, gradually advancing seawards, have adapted themselves to a marine habitat. Some of these transition forms are to be seen in Tomahawk Lagoon, as in other brackish-water localities along the coast. In speaking of them I must use technical names as they have no common or trivial names. Two forms especially, Ruppia and Zarnichellia, grow commonly towards the seaward end of the lagoon. Rooted on the bottom, their slender grass or thread-like stems and leaves float upwards, seldom reaching the surface. Ruppia exhibits a curious device in connection with its flowering and fruiting. The flowers have both stamens and pistil, and are probably quite capable of self-fertilisation. But, as is usually the case with such plants, cross-fertilisation is most likely beneficial to the race. So when the flowers are ready to open their stalks lengthen to such an extent as to float the flowers on to the surface of the water. 
Here gentle currents of wind, or perhaps minute semiaquatic insects (gnats, etc.), convey the pollen from flower to flower. As soon as fertilisation has taken place the ovaries begin to grow and develop, and at the same time the stalk begins to twist itself up like a short corkscrew, so that the fruit is ripened close down to the bottom of the water, out of the reach of waves which might tear the fragile stems to pieces. I do not think it at all likely that either Ruppia or Zannichellia conld grow in sea water, but an allied plant has acquired the power, but at the same time has lost the power of growing in fresh water. This is the Zoster $\iota$ or "Sea Wrack," which, though not found in Tomahawk Lagoon, grows in such abundance in the harbour. The banks are covered with this slender. grass-like bright green plant, which is not a seaweed or Alga at all, but a true flowering plant. Now, every tyro in botany knows that flowering plants only produce seeds when the pollen has been so placed on the stigma of the pistil as to bring about fertilisation. But pollen is not intended to be wetted, and as Zostera grows in the sea, and is either always covered with water or is only exposed at low tides, it has to produce its flowers in little watertight cases. It is thus always self-fertilised, and these cases do not decay or open until the contained fruit has set.

As we wander round the lagoon, especially on its northern side, we find great quantities of pondweed, duekweed, and the pretty little red Azolla growing, the first-named rooted in the mud and floating up its oval brownish leaves on to the surface, the two latter floating quite detached and sending down little roots to a depth of nalf-an-inch or more. Duckweeds are the smallest of all flowering plants. They have no distinct stem or leaf, but the whole plant consists of a flat green expansion or frond, seldom reaching a fourth of an inch long. In a cleft of this little sheet of tissue there grows a cluster of most minute flowers. Azolla is not a flowering plant, but is allied to the ferms. Where these plants are found in such abundance, other forms of life-both vegetable and animal 
-are also smre to be met with, and Tomahawk Lagoon is an ideal hunting ground for the man with a microscope.

As has often been remarked before, Dunedin is exceptionally well situated for the study of Natural Historyin the wider sense of that term-and this lagoon, lying as it does on the borderland between fresh and salt water, is an extremely rich repository of living organisms. A bottle full of its weeds and water will furnish material for study for many a day.

\section{1.}

Winter, to many who take pleasure in the field and the garden, is an uninteresting time, because then the operations of Nature are not so conspicuous as in the warmer seasons of the year, and life everywhere seems to them to be dormant. Such observation is, of course, only superficial, for we easily notice the partially hidden forces which are at work preparing for next season's bud and blossomsfor spring's activities, its love-makings, and its reproductive energies.

But he is a philosopher who thus sees beneath the surface of things seen, and who, from the germ hidden to common eyes can project into the glass of the future the images of things not seen but yet to be developed. As we are not philosophers, and require to see before we can become much interested, we may at this time of year again turn our attention to a domain of Nature which is as interesting in winter as in summer-the domain of old ocean. I am not sure that a walk by the ocean beach is not more full of incident at this season of the year than when the sun is in the zenith, for our summer is usually so windy that twelve hours of calm at a stretch are almost mknown. Most people walk too late in the day, probably because they are not free at an early hour. But the pleasantest time to walk on the beach is in the morning or early forenoon, especially when the weather is still and clear and the tide dead low. At such a time there are at least two zones of life represented on the beach - the resident life of the littoral or costal zone, that which lives 
on the sand above or between tide marks, and that which swims in the open ocean and which is thrown ashore by the surf. After days of very heavy weather, especially when the wind has blown from the south or south-east, the beaches are strewn with wreckage-not wreckage in the ordinary sense of the term, but that of the animal and vegetable life which dwells at or below low-water mark, and which by the great rise and fall of the waves gets torn from its rocky bed. When there is a great range of tide and at the same time a heavy surf on the ocean, the flotsam and jetsam of the beaches is found to be quite different from the other forms of beach life.

The sandhills along our shores are usually an index of a rising coast-line; I do not think they are ever found where the coast is sinking. If we walk along one of our ocean beaches we will find that while there is only a thin belt of sand at the southern or south-western end there is a very wide stretch of it at the other end-this is well seen by contrasting the beach at St Clair with that at Lawyer's Head. The same phenomenon will be found to repeat itself up or down the coast, wherever the coastline has a more or less north and south direction. Similarly, at the Green Island beach the sandhills commence on the north side of Brighton, and are at first very narrow, but they spread over a great area at Black Head, near Green Island, and are still spreading up from the sea. At low water the tendency is for the wind to keep moving the sand in a northerly or north-easterly direction. The opposite wind, the north-east, though often felt so strongly in Dunedin, is not, as a rule, a strong wind on the coast. It is here mostly localised by the form of the hills and harbour, and it does not carry much sand.

The struggle between land plants and the sea, which I referred to in a previous note, is well shown on the sandhills. There are a few plants which are only to be found in such localities, and these are characterised by their fibrous roots and long creeping stems, which can send up buds here and there even when buried under several inches of sand. These are the natural sand binders which 
tend to make the hills into permanent dry land. They are commonly plants with a wide geographical range, though locally their distribution is so limited. For instance, there is the common Euphorbia glauca, or Caper Spurge, which is found on all the sandhills from Stewart Island to North Cape. Like all its immediate allies, it is a plant which contains a great quantity of milky juice, which oozes ont in large drops wherever the surface is broken. This latex, as botanists call it, is no doubt partly a store of food material laid up by the plant for future use. It is also a most effective protection against enemies of all kinds, for it is extremely acrid. If a little drop be placed on the tongue, a burning sensation will be produced in the month and will remain for two or three hours afterwards.

Another plant only found on the sandhills, and, like the Euphorbia, also confined to New Zealand, where it ranges the whole length of the coast line, is the large hard yellowish-brown sedge or cutting-grass technically known as Desmoschoenus spiralis. * It is perhaps unfortunate that so few of our plants have simple common names by which they can be distinguished. Desmoschomus is quite a peculiar plant in its habit and appearance, and gets its specific name from the partial curving of its flowering stem, which gives it something of a spiral twist. It is one of the most efficient sand-binders we possess. Its hardness is probably just as protective as the milky juice of the Euphorbia, while its harsh cutting edges prevent its being handled with impunity. Seaside plants as a rule are either hard and dry or thick and spongy in their texture. Their surfaces are not furnished with so great a number. of breathing pores, or stomata, as we fincl in ordinary green plants which grow away from the neighbourhood of the sea, and in consequence they do not evaporate water so rapidly from their foliage and stems. One has just to think of the thick-leaved ferns (Asplenium), the native celery, the fig marigold or Mesembryanthemum, and the pretty lilac-flowered convolvulns (C. soldanella),

* In Cheeseman's Flora this species is referred to Scirpus frondosus. 
which all grow within reach of the sea spray, to realise how thick in texture many of these seaside plants are.

On a still sunny day one may lie down in a hollow of the sandhills and enjoy a most absolute rest. With the view bounded at the distance of a few feet or yards by the yellow sand or its dull green or brownish mantle, and

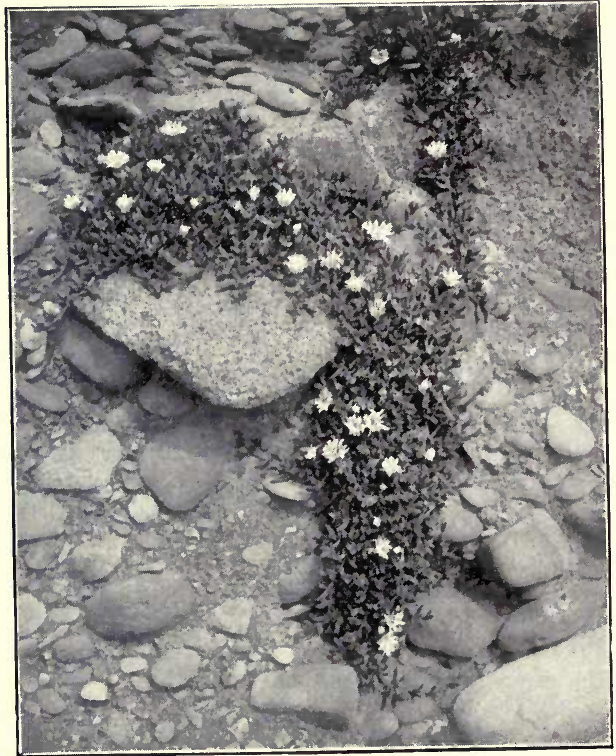

Mesembryanthemum australe.

the open sky above, the thoughts may wander into far distant regions, oblivious of the cares of life, or of the fact that we are only a little distance from the busy haunts of men. Limited as is the view, it is very restful, and to the ear there only comes the everlasting " break, break, break" of the sea. 
The animal life of the sandhills is not very abundant, a fact which to many idlers may be a great recommendation. Yet wherever plants are to be found there animals - especially insects of various kinds - are found, to eat them, and still others to prey upon the vegetable feeders. Burying beetles, carnivorous beetles, ants, and spiders, all belong to the last section, and quite a respectable collection of these can be made in any hollow where the blown sand is more or less grown over with plant life. While the plant-eater's are mostly brownish, grey, or dirty green, to enable them to lie hidden either among the foliage or in the vegetable debris of the sand, their enemies are not so protectively coloured, and trust as a rule to their superior agility or strength in the struggle for existence.

When we leave the sandhills and walk down on the beach we find that the border line between sea and land, where the highest tides and heaviest gales have thrown up the seaweed to a great height, is inhabited by colonies of scavenger's whose work is to eat up, and so clear away, the debris which collects on this neutral territory. Under the decaying weed - usually misnamed kelp - are to be found numerous flies, staphylinid beetles (with their wing cover's so short as to protect only about one-third of their body, and therefore useless to them for flight), large earwigs, sometimes small ants, and almost always sand-hoppers. In the case of the flies and beetles, we see one of those adaptive devices which meet one at every turn when studying the organic creation. Neither of these insects can fly - at least, to any extent. Had they considerable wing-power their chances of being blown out to sea during off-shore winds would be great, whereas, with enfeebled powers of flight they are saved this fatal risk. While the former are all insects, the sand-hoppers are crustacea, specially modified for living out of the water and for burrowing in the sand. Their bodies are sheathed in flexible coats-of-mail, their fore-limbs are fairly strong, so that they can rake the sand together with their feet, while with the powerful tail-end of their body they can 
throw the raked-up sand far behind them. So active are they that a big strong hopper can bury itself out of sight in a mound of clean sand in the course of a few seconds. All crustacea are voracious eater's, and when nothing else is to be got they eat each other, apparently without any compunction. Once, when walking on the beach near St Clair, I fell in with a large sand-hopper, and promptly dropped it into an empty bottle which I had in my pocket. Shortly after, I came on a larger and much rarer kind of crustacean, and dropped it into the same convenient receptacle. Unfortunately I had no preserving material with me, so I gave them a little sea water to keep them moist. On reaching home an hour or so after I took out my bottle, and lo ! there was only one specimen. It seemed a case of the lion and the lamb lying down together, but with the lamb inside; so, picking up my solitary specimen, I dropped it into a tube of alcohol, when, to my surprise, the smaller crustacean emerged from the body of the larger, only to succumb in a few seconds to the effects of the spirit. Instead of the big fellow having eaten the smaller, the little fellow had actually eaten its way into the body of the big one until it was lost to sight. I don't suppose these simple animals ever suffer from indigestion.

Besides the sand-hoppers, innmmerable little Isopod crustaceans, like small wood lice, may be seen running about on the sand a little above the water-line, ready to eat up the rarious specimens thrown up on the beach. But as they are themselves liable to be picked up by the countless gulls and petrels which roam up and down the coast, they are coloured almost exactly like the sand, and besides, when alarmed, they roll themselves instantly into a ball, which completes their resemblance to a pellet of sand.

There is perhaps nothing more remarkable on the seashore than the extraordinary rapidity with which dead and decaying material is removed. So much is this the case that the collector who wishes to gather what the sea has thrown up must do so promptly, or his material will all be destroyed before he comes on the scene. 


\section{IV.}

This is such a morning as makes us almost rebel against the fate which compels us to work indoors, and which forces us to spend our hours "cribbed, cabined, and confined" within four walls, when every natural instinct calls us out into the open air. The sky is bright, and clear but for a few light and fleecy clonds, the sun shines quite warmly, and all life seems to rejoice with the promise of spring. The bush is vocal with the songs of birds, the thrushes are piping to their mates, the timid little brown hedge sparrow utters its sweet warble of two or three notes, while a couple of lively korimakos are sounding out their bell-like gurgling tones in the gully down to the left. A Red Admiral butterfly has just flown past, apparently newly awakened by the bright warm sunshine, and oblivious of the fact that last week the ground was bound by an iron frost, and that perhaps next week it will be buried in snow. Yet it is midwinter, and only a week past the shortest day of the year. The black and pied fantails which chase one another about with untiring energy, and the perky little tomtit which flits so close to me as it utters its little twittering note, are themselves almost signs of winter, for as the breeding season comes on they go farther into the bush away from the treacherous cats, and are more rarely seen. The few bees which come out of their hives to see how the world is progressing find that flowers are scarce both in bush and garden. True the gorse is putting out its first flush of golden blossom, but its flowers are almost scentless. With all her prodigality Nature exercises a strict economy in many directions, and winter flowers are not commonly lavish of fragrance when scent-guided insects are absent or rare.

Yet the promise of spring is manifest not only in the songs and brightening plumage of the birds - the very sparrows becoming nore brightly marked and banded with grey and brown-but in many other signs. The crocuses are putting up their little sheathed buds in the flower borders; the catkins are out on the birch trees; and 
the flower trusses are beginning to show on the Clematis and native bramble. A pair of grey warblers, which built their nest on the top branches of a tall Deutzia near the house, are looking about their domicile to see what alterations are needed before they start housekeeping again. The days are each only lengthened by a minute or so, yet the increase of light and sunshine soon begins to tell on the vegetation, and makes the buds swell.

One of the brightest spots in our Town Belt at this time of the year is the brow of Maori Hill, where the ground drops almost perpendicularly into the Leith Valley. It is a charming spot in which to pause in our ramble on this bright morning, for a most beautiful panorama opens out to east, north, and west. But what a change has come over the scene since first I saw it nearly thirty years ago! In those days the whole of Pine Hill was clad in dense forest, which cane right down to the outskirts of the town in Duke Street. The Queen's Drive was not made then, and the vegetation of the Belt was more umbrageous than it is to-day, while gorse and broom and elderberry had not begum to invade and occupy all the undergrowth and open ground. Blackbirds and thrushes were unknown, but the call of the weka was commonly heard during the day, and that of the morepork at night. Stockmen would occasionally lose a wild bullock for a week at a time in the dense scrub at the north end of the town, so that it was not always safe to ramble in the neighbourhood.

From a botanist's point of view the change in the vegetation due to the clearing of the bush and the invasion of introduced plants has been very great, and it may be of interest to record some of the disappearances, not only about the north end, however, but all round Dunedin.

One of the first effects which follows from the clearing of the bush is the decrease in humidity of the soil and air, and as a consequence many of the most delicate ferns and mosses become dried up. Formerly, of course, these fragile plants grew down to the water's edge over a great part of the site of Dunedin; even in the seventies they could be got among the undergrowth and large trees at the 
end of Duke Street. There grew such delicate filmy ferns as Hymenophyllum rarum, australe, and subtilissimum (pray excuse such long names, which we must adopt in default of any better), besides many commoner species. The tiny fronds are only one cell thick, and in a dry atmosphere the moisture evaporates from both surfaces quicker than the small roots and slender stems can supply it. There may be a few shady spots and sheltered gullies about Pine Hill and Mount Cargil where these tender plants survive, but as a rule one has to-day to go many miles back in the bush to find them. They are things of the past as far as Dunedin is concerned.

The first time I went up Nichol's Creek, before the days of roads and fences, gates and tolls, the banks were thick with filmy ferns, mosses, and liverworts, and single and double grape ferns. On the moss-covered stones in the creek bed were clumps of the curious little purple spiderlike orchid Corysanthes rivularis, intermingled with tufts of the white-flowered Oxalis magellanica or wood sorrell. They are all gone, dried up or trodden under foot, and one must go far to find their nearest neighbours.

Along the south side of the Leith, on the slopes above I'Glashan's Mill, there used to be several fine specimens of the "milk tree" (Epicarpurus microphyllus), which exuded a quantity of milky sap when its brittle branches were broken. Most, if not all, of them are now gone.

Leaving the Leith to follow up Ross's Creek towards the reservoir, the damp dripping green walls of rock on the right hand which formerly used to yield such a rich harvest to the microscopist are now nearly dry and bare; while the forest-clad slopes which kept them moist are now cleared and more or less occupied by cottage gardens. The Wakari or School Creek, which has its origin close to the old school at Halfway Bush, and joins Ross's Creek halfway between the mill and the reservoir, was formerly a clear stream; and the famous Forty-foot Hole-so called, 1 suppose, because it is not 40 feet deep-the delight of Kaikorai boys, was an ideal bathing place. But we have changed all that. A fellmongery or wool-scouring estab- 
lishment-one of those useful abominations-is located at its head waters, and the brook is now about as uninviting as the Kaikorai Stream itself below Burnside. The bush in this gully was quite a noted collecting ground. Here grew the delicate little Cystopteris fragilis - a fern which is common enough in many parts of the world, but is not found, or at least not known to occur, elsewhere in any part of this neighbourhood. Here also were recorded the only local examples of two North Island species of hinahina-Melicytus macrophyllus and $M$. lanceolutus - but both seem to have disappeared, though the latter form is still to be met with in the West Taieri bush.

The Belt itself has lost many of its less hardy natires, choked out in all likelihood by stronger and coarser aliens. Patches of the remarkable grey and green mottled orchid (Gustrodia), whose colour suggests that it probably grows in decaying organic matter, used to be common in the bush. Native myrtle, the heart-shaped leaf of which gives it its name of Myrtus obcordatus, formerly grew on the slopes behind Royal Terrace. Here also one often came across the fronds of the moonwort (Botrychium), that odd fern which puts up only one frond each year, though it has been maturing it for three years underground. On the grassy ground, before coarser vegetation choked it, were to be seen the delicate little green fronds of the adder'stongue fern (Ophioglossum).

On many a rocky cliff-for example, where the Anderson's Bay road winds round just beyond Nusselburghgrew patches of Angelica, more commonly known as " anise," but these have either been eaten out by cattle or. have been choked out by hardier plants. All sorts of stock eat the "anise," and rabbits are very fond of it, so that it is not to be wondered at if the plant disappears from many parts of Otago. But where nothing can get at it it still thrives. There is a shelf of rock on the Main South Road just beyond Look-out Point, inaccessible for animals from above and out of the reach of men from below: on this up till a short time ago " anise" was always to be found.

On drier and more exposed localities, like the cliffs above 
the old Anderson's Bay raitway line, there formerly grew tufts of a little fern (Cheilanthes tenuifolia) which we must reckon among the things of the past. At Black Jack's Point, near where the stone-crusher now stands, there used to be a fine specimen of the long-leaved heath,

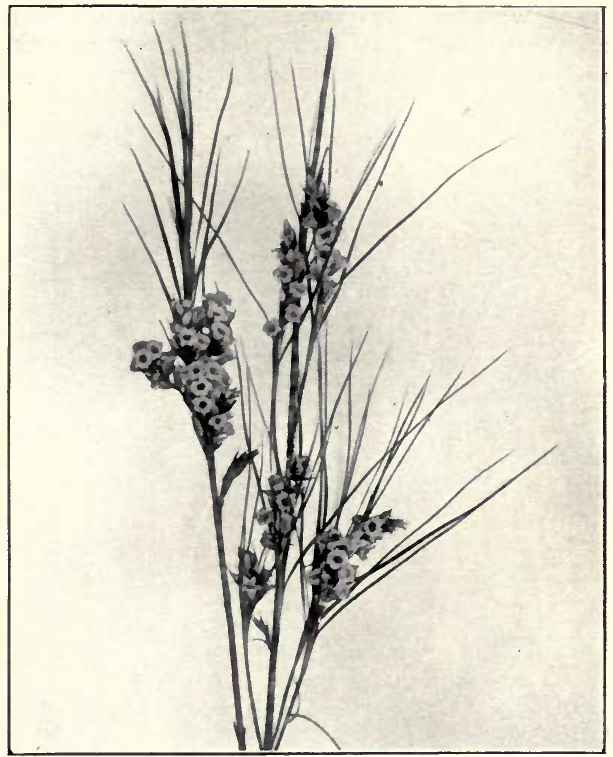

A long-leaved heath (Dracophyllum longifolium).

Inacophyllum longifolium, over 20 feet high. It was apparently the last of its tribe within a radius of some miles, but it was destroyed when the railway line was made. Similarly the making of the roadway round the further side of Pelichet Bay cleared away many of the last 
specimens of the tortuous Plagianthus divaricatus to be found in this neighbourhood.

I could go on multiplying this list were it not that the mere iteration of technical names, which are the only ones we often have to designate our plants by, becomes tiresome. Those referred to, as well as some others not specified, were formerly common hereabouts, but have now disappeared wholly or partially, though still common enough in many other parts of Otago. They have shared the fate of the Kaka and native Pigeon, which cannot exist near the busy haunts of men. 


\section{Chapter IX.-July.}

I.

JULY is the coldest month of the year, and though the days are lengthening appreciably, yet the ground is probably more thoroughly chilled than at any other season, and vegetation is correspondingly retarded. The severity of the weather in this and succeeding months is seldom, however, due to mere lowness of temperaturethe amount of moisture in the air is a much more potent factor. Thus a succession of hard frosts does comparatively little damage even to half-hardy plants if the weather is dry; but a fall of a few degrees below the freezing point following close upon rain or snow will probably destroy or cut back a number of delicate plants which nray be able to survive many winters when the conditions are more equable. Our most destructive frosts nearly always are the result of clear nights, when there is comparatively unchecked radiation, after days of rain.

The severity of a winter season has probably very little effect in retarding the development of vegetation in the following spring and sumner. In the case of both biemnials and perenuials the vigour of the growth, and especially the development of flower and fruit, depend on the amount of growth in the preceding summer. This again is probably more largely dependent on the amount of light than of heat, for the more plants are subjected to light in their period of growth the greater the amount of material they are likely to store up in their stems and roots for the next year's time of fruition.

July is a rather dead season for the botanist. Of native flowering plants with conspicuous flowers very few are as yet to be met with in flower. As sometimes happens, even in June, early examples of the Fuchsia and of the kowhai 
(Sophora tetraptera) are occasionally to be found, the latter especially on sumny hillsides. Both of these plants it must be remembered have their flowers fertilised by birds not by insects, so that in this respect they are not dependent on the season. The species of Fuchsia found in New Zealand are peculiar to these islands, while the genus is chiefly developed along the whole length of the great mountain chain of the Andes. But the kowhai-the same species as occurs here-is also found in Chili and Juan Fernandez, a distribution almost the same as that of

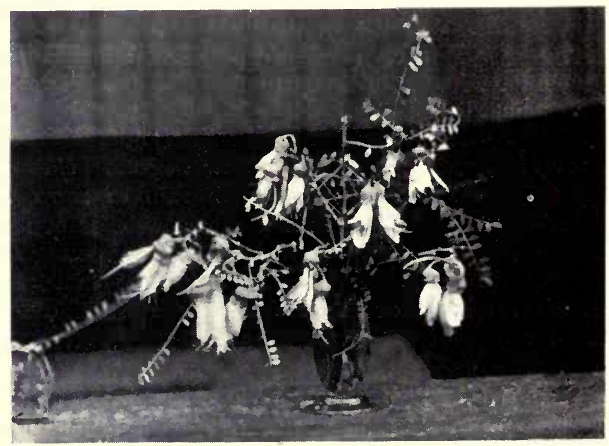

Kowhai (Sophora tetraptera).

our common tutu. Both kinds of plants are probably relics of an Antarctic flora which formerly overspread the now icebound lands of the Antarctic Circle at an age when the climate of that most inhospitable region was like that of the present warm temperate zone. The kowhai is interesting to the botanist for several reasons besides that of its geographical distribution. It belongs to the great natural order known as the Leguminosæ, and to that division of the order characterised by flowers resembling those of the common pea. This kind of flowers is usually so well marked in its general appearance that almost any 
one-peas, beans, lupins, clovers, broom, etc.-might be taken as a type of all the rest. There is a calyx nuale of five joined sepals, a butterfly-shaped corolla (hence known technically as papilionaceous) made of five separate and oddly-shaped petals; and ten stamens, which are either all joined into one tube, or of which nine are joined and one stands by itself. Another of the divisions of this large order, one which is not represented in New Zealand, is called the Crsalpinex; the flowers in this group have the petals nearly sinilar in size and shape instead of being irregular and butterfly-like, and the stamens are all separate from one another. Now, the kowhai is a sort of link between these groups, for although its affinities are mainly with the Papilionacea, in which group it is placed by systematists, its petals show a considerable leparture from the pea-like character, and its ten stamens stand all separate from one another. Whether these are prinitive characters, which seems most likely, or reversions due to the mode of fertilisation of the flowers, it is not possible to decide; but we may safely infer from the wide clistribution of the genus Sophora in tropical and sub-tropical regions, as well as from the peculiar charctcters of the flowers, that it has retained its special features from a long-buried past or, in other words, that it is a very old genus.

Though conspicuous flowers are almost wanting in July (it would scarcely do to say they were conspicuons by their absence), there are many plants whose inconspicuons flowers are still to be found. Such flowers, of course, are not dependent on insects, but are mostly self-fertilised, or-as in the case of so many introduced catkin-bearing species-they are fertilised by the wind. Many of the commonest gardell weeds - sowthistle, groundsel, chickweed, and others-which flower all through the winter with aggravating regularity, are thus self-fertilised. Of native plants, one of those worth looking at is our only species of spurge-Euphorbia glauca (referred to at p. 113). It usually flowers later in the season, but may be met with this month. It is a pale-green erect herb, two feet or more 


\section{26 A NEW ZEALAND NATURALIST'S CALENDAR.}

in height, which grows commonly in the sandhills along our shores, and is easily recognised by the great drops of milky juice which exude from it when it is cut or broken. The only way to know a thing well is to know it at first hand, and therefore if you want to learn what this juice is like you may touch your tongue with ever so little of it. The effect is not immediate, but it gradually reveals itself to your awakened senses as a burning heat which seems to pervade the whole mouth, and which lasts - as far as I remember-for a couple of hour's or so. It is not very painful, at least, a small quantity is not, but it is sufficiently so to discourage future experiments of the same nature. The flowers in all these Euphorbias are very peculiar. Neitluer sepals nor petals are present, but at the ends of the branches-almost buried among the terminal leaves - there appear's a flower-like cluster consisting of about five bracts, each crowned with a purple crescent-like gland and enclosing two kinds of imperfect flowers. Each staminate flower consists of a single stamen jointed on to a short stalk, and in the midst of a cluster of these stands, or rather hangs, a single pistillate flower with three short styles. Of course, to most people, these flowers do not appear worthy of the name; but botanists mean by the flowers of a plant its reproductive organs, whether they are showy or not. Of imperfect and inconspicuous fowers this is about as good an example as one could get, because its parts are not too small to be easily made out.

Most of our succulent-fruited plants have lost their fruit by the beginning of this month-at least, in the neigbourhood of Dunedin-but this is probably due to the enormous increase of blackbirds and thrushes. In the denser and less broken portions of the bush many yet retain their fruit, and among these the mistletoes are noteworthy. Five different kinds are found in this neighbourhood, but of these I do not know the fruit of the two species of Viscum, * most curious little leafless parasites, which are not uncommon on manuka, coprosma, and other shrubs,

* V. Lindsayi and $V$. salicornioides. 
but which are very easily overlooked. Tupeia antarctica, a pale green plant, is our commonest mistletoe, and its berry is either of a clear white colour or pink with lilac-red blotches. Loranthus micranthus is another common form, with rather large dark-green leaves and small

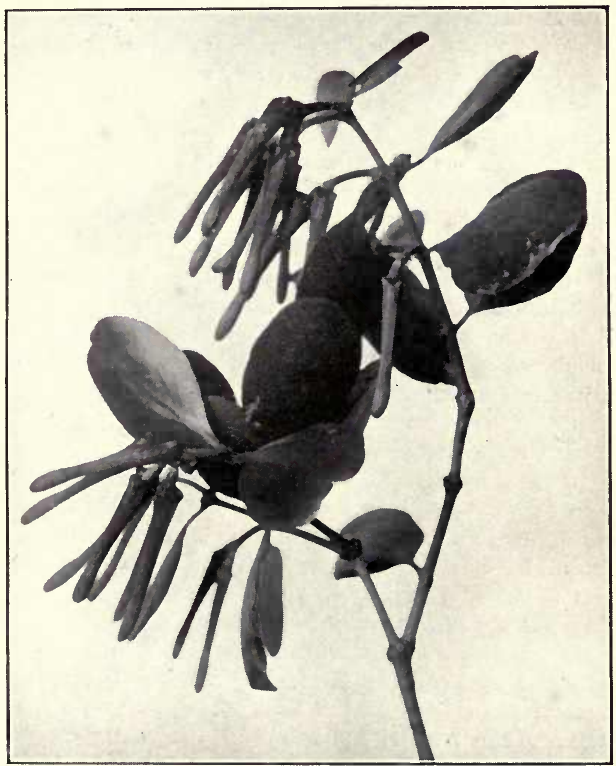

Scarlet Mistletoe (Loranthus colensoi).

berries of a bright orange-yellow colour. The beautiful scarlet-flowered mistletoe (Loranthus colensoi) so commonly found on the Fagus, or beech trees, in the forest along the foot of Maungatua, bears a larger orange-yellow berry. All these kinds are eaten by birds, which thus 
distribute the seeds. But it shows how specialised such a form as $L$. colenso $i$ is, that it is not more widely distributed. Its seeds, like those of the other kinds, must not only fall on the branch of a tree, but if that tree does not happen to be a Fagus their chance of survival would seem to be small. In the old Country people graft the common mistletoe- Viscum album-on to apple and oak trees for the sake of the Christuras harvest of berries which they yield. It would be worth while here to try grafting the scarlet mistletoe in a similar manner, for its flower's are very attractive. I have in the past tried to cultivate it, but though the berries were tried in all sorts of waysplaced in cracks on the branches, in slits in the bark, or fastened on with clay or mud, and on a variety of treesI was not successful in a single instance.

There is but little animal life visible in mid-winter, except the different kinds of birds, native and introduced, which are so readily observed at this season; but there is plenty of hidden life for those who care to look for it. I remember on one bright July day, some years ago, that a party of us were examining some fallen totara trees in a bush clearing. As we stripped the loose bark off one of the trunks we uncovered a number of greyishbrown lizards-probably the common Dactyloenemis maculalus-lying in a semi-torpid condition. They were carried home and deposited in a dry aquarium case, fitted with pieces of wood and stone, and covered with a looselyfitting lid. During very cold weather they remained sluggish, but during the warmth of each sunny day they brightened up very considerably. Two of them lost or shook off their tails at the time of capture, but neither. of them seemed to be the worse of the loss. I kept all of them till the beginning of November, though they hardly ate anything. But with the advent of wam weather a remarkable change came over them. Between the second and seventh of the month they got rid of their old skins, which peeled off them like pieces of very thin worn glove, and they emerged bright and clean as contrasted with their former dirty grey appearance. They 
also ate small pieces of meat and liver freely. But the most remarkable thing about them was their activity. Formerly they apparently could not hold on to the glass walls of their prison, but once their moult had taken place they ran up the sides quite easily, and in spite of the lid, which was more closely fastened on, they all managed to escape within a week.

Young people here do not go in for pets so much as is done in the old Country-more's the pity. For those who do, if their mothers will let them, I recommend a case of lizards as a very interesting object lesson. Only remember the cat is rather fond of lizard.

\section{II.}

There is an extremely interesting zone of life represented in that border line between sea and land which exists on all rocky shores, the zone of the rock-pool, as it might be termed. It is not particularly well represented near Dunedin, but is well seen at Brighton and some other points on the coast where reefs of rock project to some distance from the shore. On these the sea continually breaks, and as the tide recedes it leaves pools in all the cracks and hollows. In such localities, where the water is always highly aerated and saturated with dissolved oxygen, and where there is the maximum amount of light with sufficiency of moisture, marine plant life grows to the greatest perfection. On these sea-washed rocks grow seaweeds of all kinds and colours, delicate red and pinkfringed forms ; stiff grey, lilac, and pink kinds, having their cells hardened with chalky matter to give them rigidity sufficient to withstand the dash of the waves; bead-like forms varying from delicate green thread to large nearly black beads; and-most common of all-the large green, olive-green, and brownish tangles, which include among them some of the largest plants known. All these belong to the group of plants known as Algæ, a group of comparatively low organisation as compared with many other forms of plant life, and comprising an immense variety of organisms. One of the commonest seaweeds 
which grows on the rocks and reefs of our coast, forming the best natural breakwater they possess, is the huge Macrocystis, which usually grows 50 feet or more in length, and is said by Hooker to reach " 700 feet or upwards." From these giants we reach, in a diminishing series, minute unicellular plants, not more, perhaps, than one-thousandth of an inch in diameter. Yet all belong to the same vast family of Algæ. It is curious to recall the fact that when Linnæus, nearly 150 years ago, classified plants, he divided the flowering plants into twenty-three orders, and assigned all the rest - the non-flowering plants (including Alga, Fungi, Mosses, Liverworts, and a host of lower organisms) - to his twenty-fourth order. The fact of his classifying them so does no discredit to the ruarvellous classificatory powers of the great naturalist-it only shows how vastly the knowledge of these humbler forms has been increased, so that now Limnæus's twenty-fourth order is known to include far more forms of life than all his twenty-three others, even though the flowering plants named so far number between two and three hundred thousand.

But to come back to our reefs and rock-pools, from which let us hope the tide has receded to its farthest limits. Where plant life is so abundant animal life is sure also to abound. Nearly all families are represented, of course by forms specially modified for living under the special conditions of the littoral zone. A feature of many of them is that they are protectively coloured so as to escape observation: dark green worms may be seen creeping over the green weed; in some places on the weed are green shrimps, while in the bottoms of the pools are reddish and sand-coloured species. Here are amphipods of most elegant colours (allied to the sandhoppers) swimming in the pools. They are often of most elegant colours, spotted or banded with blue, brown, purple, or black, on a grey or pink ground. Placed in a small transparent vessel of clear sea-water they look bizarre and conspicuous; but try to find them as they swim to a bit of coloured seaweed and rest on its fronds-why, they are almost invisible. Here we meet with pearly-white or lemon-yellow sea-slugs 
creeping along the pools, so conspicnous in their movements and colouring as to suggest that they do not need protection. Probably they have a taste which is objectionable to the large marine carnivora, and are desirous to proclain their identity, so that fishes and other mollusc-eating animals may make no mistake about them. On the other hand, the edible molluses, like oysters and mussels, are furnished with a good thick shell by way of protection. The little fishes of the rock-pools are usually parti-coloured, like the amphipoda-black, grey, and white. They dart hither and thither with rapidity, and when resting on the bottom or among the weed are almost indistinguishable from their surroundings. Even the pretty sea-anemones are coloured in exquisite harmony with the rocky beds in which they hide; but here it is not protection they seek, but something very different. How deep-seated in Nature lies the principle of deception! These innocent-looking lumps of jelly, whose whole inside is a digestive cavity, spread out their petal-like tentacles in a radiating ring, ready to grasp and engulf any unwary animal which comes within their reach. Having no means of progression, and consequently of aggression, they must resort to deception to eatch their prey. So they assume a flower-like appearance, and when fully opened are remarkably beautiful organisms. The thing which strikes one most when considering these facts is how certain forces in Nature have worked through countless generations of organisms, modifying their structure in whatever direction will bring them into and keep them in accord with their surroundings, so that we are almost compelled to speak of these organisms as if they were themselves conscious agents in this work of evolution.

If we turn over some of these stones near the rock-pools we shall almost certainly disturb a colony of crabs. Here are large purple-spotted ones* like the stones they hide among, and there are olive-green or brownish species more like the seaweeds in hue. They hide while the tide is low, 
because, though coloured in conformity with their surroundings, it is not protection they need in the water but such similarity of hue as will enable them to get near their prey without attracting notice; but were they to move ont from the shelter of some friendly stone into the open they would run the risk of being picked up by some passing gull. Against such an enemy their strong nipping claws, which are such excellent offensive and defensive weapons, would prove of no avail.

Or perhaps we may disturb a colony of porcelain crabs* -small bluish fellows with disproportionately big, angled, and flattened claws. If we take one up between the finger and thumb, gripping it by the back of the carapace, and offer another finger to its claws, it will astonish us, small as it is. Most singular of all are rather large crabs $\dagger$ with feeble claws, covered on the back with tufts of hair, serpulæ, and seaweeds, sometimes carrying a bunch of sertularians, a barnacle, or even a sea-anemone, to increase their resemblance to a seaweed-covered stone. This is a defensive, not an offensive, device. They hope to escape notice by their resemblance to the ground on which they move or rest. But all Nature abounds with such devices, and we meet with adaptations of the kind in every realm. When these animals moult or change their shells, which they do periodically, the new shell is smooth, but with their claws, they seem to plant other organisms on their backs, so as to secure this covering growth as quickly as possible.

Many of the plants and most of the animals of the rockpools can be kept in an aquarium, and their beautiful forms and movements studied leisurely. But to keep an aquarium at all takes some practice and due consideration of the natural conditions under which the denizens of the pools live. The water must be kept at uniform density by daily additions of a little fresh water, it must have constant aeration, a judicious mixture of plant and animal life, and, most important of all, too many living things must not be crowded into a small space. By attention to these details

* Petrolisthes elongatus.

+ Paramithrax latreilli. 
I have known people in the old country, who lived miles away from the sea, keep a salt water aquarium for years with very little renewal either of its living forms or its sea water.

Let us now leave the rocks and walk along the beach while the tidle is still receding. The lower the tide and the calmer the sea the more likely are we to meet with objects of interest which have been washed ashore. This seems at first sight rather an unlikely thing, but the fact is easily explained. There are numerous organisms, known as pelagic from their living in the open ocean, which are always afloat. When the surface of the sea is disturbed by wind they sink to a greater or less depth till they are below the troubled water. But when the weather is calm and bright they swim close up to the surface, where apparently they enjoy the increased light and the larger supply of oxygen. When they get on to a sloping coast line, such as occurs along the greater part of the east coast of this island, they frequently float or swim so close in shore as to get into the break of the waves, and then they are powerless. Of course only a small proportion of those which get into the range of the surf are actually washed ashore, but they are always liable to be stranded. It is in this way, for instance, that the Frost Fish* gets thrown up on the beaches. A great deal of mystery has been made about these fish. It has been suggested that they live normally at great depths in the ocean, and from some unknown cause have come up to such an elevation in the water that their swinming bladders burst at the reduced pressure, with the result that the fish are stranded in a dying condition. But examination of the swim-bladder does not bear out the suggestion. Again, it has been affirmed that their stomachs are always empty and their food unknown, and, consequently, that it cannot be search of food which has brought them into the surf. Still others have conjectured that they suffer from aberration of the intellect, or even sheer cussedness, which impels them to 
self-destruction. The facts are that they are very voracious fish (you have only to look at their enormous jaws and teeth to see that), which pursue sprats and other small fishes greedily. In still weather the small fry swim near the surface, and often close inshore, and the frost fishes follow them. If in the course of their pursuit they get into broken water, their deep ribbon-like shape render's escape somewhat difficult, and, instead of getting out to sea they frequently head straight inshore, and so land themselves into shoal water. Frost fishes are not often thrown ashore on the open beach at St Clair or Green Island; the sea breaks too far out, and they are thus probably warned of their danger while still in deep enough water to escape. But on the more gently sloping and sheltered beaches about Purakanui Bay, and especially at Hampden, they come ashore very frequently in still weather in the winter months; hence their popular appellation. The frost fish is by no means confined to New Zealand waters. It is common in the Mediterranean, and ranges in the Atlantic Ocean from the southern shores of Britain to the Cape of Good Hope, and is elsewhere known as the "Scabbard Fish."

Occasionally one picks up on the beach a little ribbon fish, a delicate little strip, perhaps nine inches long and an inch in depth, nearly as thin as a ribbon, and of a glass-like transparency. It is now known that those fragile organisms are only young eels at one stage of their life history, and that had cruel fate not washed them ashore they might ultimately have grown into eels capable of living in a fresh water stream or lake, or even of lying submerged in the damp mud at the bottom of some nearly dried up lagoon.

Very many, if not most, pelagic organisms are transparent and glass-like; the jelly fishes and Portuguese men-of-war, the salps and the crustaceans, all partake more or less of this character. No doubt this transparency aids them in escaping the notice and kind attentions of their enemies. Of the crustaceans, perhaps only one need be specified, not only because it is of very peculiar form 
and habit, but also because it is extremely abundant and well known. At least, I am often asked about it. There are frequently to be found washed up on the beaches little structures like glass barrels, about an inch long, and open at each end. Each contains a delicate transparent shrimplike animal,* which, by the continuous waving of its ablominal feet, keeps up a constant circulation of water in its domicile, and also causes it to move rapidly forward. The barrel is the empty shell or test of some kind of salpa, and the crustacean is an amphipod. It has large but very feeble claws, and relatively very large eyes. Placed in a glass of clear sea water this animal is a singularly beantiful object. Its body is so transparent that it is often possible to see the internal movements with a magnifying glass, the pulsations of the heart and the working of the alimentary canal being quite visible.

But this Phronima, as it is called, is only one of the many curious things which the sea yields up in this calm frosty weather. When the garden and the wayside are spellbound by the iron hand of frost, the sea still furnishes innumerable treasures to the eye that looks for them.

\section{III.}

For the naturalist there is an immensely wide field lying close to our own doors in the study of these living forms which inhabit our seas, and of which we really know very little as yet. If we walk round the shores of the Harbour, and, picking up some of the small weed that grows between tide-marks, shake it in a glass of sea water, we find that we have disturbed great numbers of little organisms, which swim about vigorously, or sink to the bottom of the ressel and seek vainly there for the shelter out of which they have been so rudely shaken. Many of them are so small that they only reveal their singular forms under the microscope. These shore-haunting forms of life, numerous and interesting as they are, are really, however, few as compared with those which swim in the open water, and

* Phronima nova-sealandia. 
which do not require the shelter of the plants or stones of the beach.

To collect them we must employ some kind of fine net and tow it after a boat, and this process is not as easy in execution as in design. Steamers and most sailing boats usually go too fast, and as the stuff of which the tow-net is made must be of very fine mesh, such as muslin, too high a rate of speed simply tears the fabric to pieces. Besides, the opportunities of going out into the open sea in sailing boats are neither numerous nor altogether welcome to the average landsman, so that without special arrangeents it seems at first sight difficult to secure opportunities of collecting such materials. One method which was suggested and carried into practice by Professor Herdman of Liverpool is both ingenious and successful. A continual supply of sea water is available on board steamers for washing decks and other purposes, and by simply placing a muslin filter under the hose pipe when it was not in regular use he procured a great supply of pelagic material. Indeed on some trips of the Atlantic liners the supply of minute crustacea was so great that they were cooked and served at table as a special luxury under the name of "shrimp paste" on toast.

In Otago Harbour I have utilised the tidal current in much the same manner and found the plan fairly successful. For twenty hours out of the twenty-four the lightship, which was formerly moored in the lower harbour to mark the channel, was in a strong current due to the great ebb and flow of the tide, and on various occasions in past years I have spent the night on board the little craft (in the days when the well-known Griff Jones was lightkeeper), and have kept the tow-net over the side for hours, filling in all spare time in examining and preserving the material collected by it. Such work is always most successful when the air, and consequently the water, are perfectly still, as under such circumstances the small organisms swim right up to the surface. If there is any break on the water they tend to sink to a depth of several feet. Hence I have always got the best 
results on clear frosty nights in winter, though boating at such times is neither particularly warm nor exciting. Recently, when out with the trawling steamer in Tasman Bay, I got very good results on two warm caln days, but unfortunately on the last of these a little breeze sprang up and my net went to pieces. On a dark still night, after the net has been over the side for an hour or more, it is drawn on board and turned inside out into a jar of clear. sea water. In the process the edges and lining of the net gleam with bands and points of silvery nebulous phosphorescence, many of the smaller shining points being due to organisms so minute that they cannot be made out without the aid of a good lens. It is to be regretted that to make any complete scientific investigation of these little animals it is necessary to kill and preserve them ; for they cannot be kept alive in confinement unless one has a well aerated aquarium, and even then they must be taken out of the tank and be placed in a small drop of water for close examination. The colours and forms of many of them are wonderfully beautiful, but the exquisite tints of the living creature, as well as their phosphorescence, fade and disappear in death. It is possible for a time to preserve many of the hues in such a medium as formalin, but the best general preservative is alcohol, and this destroys nearly all colours and reduces all transparent organisms to an unifor'm yellowish-white opacity.

The number and variety of the living creatures which are thus found floating in the ocean are very great, and quite bewildering in their complexity of form. Probably the most abundant both in kind and in individuals are small crustacea, but, in addition, delicate little jelly fishes, a few worms, an occasional pipe fish, and the floating eggs of several kinds of fish, are taken, as well as a few vegetable organisms.

Of the crustacea, the commonest forms belong to the family known as the Copepoda (or oar-footed). These are usually very minute animals from a fiftieth to a tenth of an inch in length, furnished with long sweeping antennæ in front, with several pair's of beautifully branched plume-like 
feet on the underside of the body, and ending in a forked tail, which is also often finely plumose. The eye (or closelyapproximated pair of eyes) is usually coloured some bright hue, most commonly red, while in some species little bands or splashes of colour-red, blue, or yellow-set off the delicately-formed little creatures. In some of the hauls made in Tasman Bay the water in the bottles into which the tow-net was washed became almost pink from the abundance of a little copepod with a series of bright red markings in its borly. I cannot state exactly where the phosphorescent light comes from, but many kinds are brightly luminous, and this luminosity is probably of some sexual importance. These animals dart about with great rapidity, their jerky motion in the water being due to the rapid and simultaneous sweep with which they move all their fringed feet. Insignificant as they appear individually, they constitute by their very number one of the most important forms of life which occur in the ocean, for they are the chief food of larger animals, while they themselves feed on microscopically small rhizopods, foraminifera, diatoms, and other animal and vegetable organisms.

Another peculiar type of crustacean life taken in the surface-net is furnished by the larval forms of crabs and crayfishes. Fishermen here occasionally speak of finding or seeing the young of the lobsters which were liberated on the mole at the Heads some years ago, but they are apparently quite ignorant of the fact that the young of all these higher crustacea pass through many curious metamorphoses before they assume the adult form. Not only are these larval forms of glass-like transparency, but they are often of most fantastic shape, and are ornamented with most complicated ontgrowths of spines, so that they are ntterly unlike the mature animals which produced them. It will give some idea of this extraordinary unlikeness when I mention that the earlier workers in this field of natural history constituted a whole family - called the Phyllosomidæ from their leaf-like appearance-with distinct genera and species, out of the metamorphic forms of the common marine crayfishes. 
Among all these forms of beantifully-shaped little animals-and I have only mentioned two types so far-one commonly meets in tow-net gatherings with numbers of very small transparent spherical masses which look like little specks of jelly. We do not know enough about them yet to tell one sort from another, but these are the pelagic eggs of several kinds of fishes. It is a curious device for the dispersal of marine fishes that they should produce such myriads of small eggs, which float up to the surface of the sea and are thus distributed by the ocean currents. Flounder's and soles, ling and cod, all produce the same floating type of egg, and in enormous numbers. A female ling will liberate $10,000,000$ eggs in a season, and as ling do not increase suddenly in number, it is safe to assume that on an average 9,999,999 eggs or young are destroyed for every one which reaches maturity. The young fish after hatching are also pelagic, and it is only after development has proceeded to a considerable extent that they gradually sink to the bottom of the sea and move towards shallow waters. So when the Govermment closed om Upper Harbour to seine netting they probably did a wise thing, not because flounders and other flat fish spawn in such waters, but because the young fish, after they have passed through their pelagic stage and gone down to the bottom of the water, and while still very small in size, find their way into shallow bays and estuaries and there grow to adult size if not disturbed.

The transparency of most pelagic organisms is no doubt a device to render them all but invisible to their enemies, so that individually they are likely to escape capture. But neither their invisibility nor their minnte size are any protection against their absorption in millions by such gigantic animals as the baleen whales, which collect them in vast numbers in their huge filter-like jaws, and indeed live entirely on them. No wonder then that the animals which live their whole life as free-swimmers in the ocean are so enormously abmolant, or that those which pass through an early phase of their existence in this form, reproduce in such numbers. In order that they may 
survive the tremendous deathrate to which they are subject their powers of reproduction must be very great.

These thoughts and ideas do not all pass through one's mind when waiting on deck in the small hours of a July morning to draw up and examine the tow-net. At such a time the tendency is rather to ejaculate "Cui bono?" and to wish oneself in a warm bed. But out of such nocturnal expeditions much matter for future hours of pleasant research may be gained. 


\section{Chapter X.-August. \\ I.}

A UGUST, like February in the Northern Hemisphere, is A usually a bleak cold month, with broken weather; but the days are lengthening, the buds are swelling on the trees, the crocuses make the gardens quite gay in sunshiny hours, and in all bright weather there is a feeling of Spring in the air. The birds are already preparing for the nesting season, and the wanderer in quiet paths coming suddenly on busy blackbirds or thrushes sees many a fight between rival males. It is wonderful with what absolute abandon a couple of blackbirds will fight; they attack each other with such fierceness and savagery - with beak and wings and spurs - that they can almost be canght by the hand, so engrossed are they in the scrimmage. I have come upon them while so engaged and marvelled to observe the state of exhaustion which ensues after such a fight, when they sit almost on their tails, facing one another with their golden beaks wide open as if gasping for breath, until the more vigorous suddenly renews the attack. Male thrushes also engage in prolonged fights, but for a regular hammerand-tongs rough-and-tumble struggle nothing can excel the blackbirds. It beats cock-fighting. After the battle the successful warrior forthwith pairs with the hen of his choice, and his beaten rival looks elsewhere for a mate. The song is suspended until this union is consummated. But out in the open, even early in August,

\section{"The skylark sings}

High in the blue, with eager outstretched wings,

Till the strong passion of his joy be told."

The native birds which have come in near the haunts of wen during the earlier months of Winter now mostly seek the denser bush in which to build their nests, only a very few being found within the limits of the Town Belt. One of these, one of the prettiest little birds in New Zealand, is 
the grey warbler,* which usually begins building this month. As mentioned before (at p. 39), a pair used to build in a Deutzia bush just a few feet from my study window, and for three years they nested in the same spot. The nest, which is a well-built cosy little structure, lined with moss or feathers, hangs on a branch or in the fork of a bush, and has the entrance slightly domed over Within this flask-shaped structure are laid about four delicate little eggs, which are nearly white in colour, but always more or less spotted or marked with pink or reddish specks. The birds must rear two or three broods of young each season, for it is nearly always in the nest of this songster that the cuckoos - both the long-tailed and the shining species-lay their eggs, and this takes place usually in December or January.

The pied fantails also begin building this month, but 1 have not known of them nesting about the Belt for some years, though they probably do so in the thicker portions furthest away from roads and houses. A score of years ago they used to nest close to the High School Rectory, and whenever the windows of the dining hall were open they came into the room, and not only cleared off the small flies from the window panes, but used to search the woodwork of the lofty roof for spiders. The nest is a beautifully built cup-shaped edifice, and the eggs, in number, size, and colouring, resemble those of the grey warbler.

The grey lark or pipit, a very common ground-bird in the open country, regularly begins nesting during this month. Like all birds of its kind, it makes a shallow nest of grass, usually at the foot of a tussock, and lays three or four greyish eggs, which are generally more or less streaked with darker markings.

Occasionally the miro-miro or yellow-breasted tit makes its nest in Angust, but usually it waits till the spring is more advanced. The late Mr T. H. Potts, who was a most observant naturalist, recorded this species as nesting in all sorts of queer localities, not only among the branches and

* Gerygone flavizentris. 
leaves of various kinds of trees and shrubs, but in hollows of decayed trees, on the face of a high cliff by the sea, in crevices of rocks, under the arch of a bridge on a public road, in porches, sheds, and outhouses. And in such localities as those last named, rags, bits of paper, and worsted, were worked into the nest. I know of no native bird which has shown so much confidence in human beings as this perky little bright-eyed tit. When so many of the indigenous birds have retired permanently to districts remote from all settlement, it is pleasant to feel that some have remained, and that, in spite of their fearlessness, they have managed to survive near towns and beside the habitations of men. It would be well if the rising generation of boys could be instructed and prevailed upon to leave them unmolested.

In the month of August many plants commence to flower, but the majority of those which are borne by trees or shrubs are either self-fertilised or are dependent on the wind, as insects are still comparatively rare. The most familiar examples of wind-fertilised plants are to be found among the introduced catkin-bearing trees - willows, poplars, alder's, hazel, and many others. It is noticeable in them that the catkins are borne on the branches before the leaves appear, so that they hang open and loose to the action of the wind.

Perhaps the best examples of wind-fertilised plants in the native flora are furnished by the genus Coprosma, some species of which come into flower this month. How am I to describe the Coprosmas so that those unacquainted with them may recognise them? Well, they are very common plants in the Town Belt, particularly in the more open parts, and they are known to most people in one or other of their species. The larger-leaved kinds have shining leaves and longish orange-coloured drupes (or berries, as they are popularly called). The smaller-leaved kinds have usually a scrubby kind of appearance, with branches coming off at very wide angles, widely-separated pairs of small leaves, while the fruit is generally small, round, and bright red in colour. One species with a very decided 
odour (appropriately called Coprosma foetidissima) is popularly known as stinkwoor. Another, with narrow small elongated leaves and bright yellow wood, is the mika-mika; while still another, common on dry banks, has striped blue and whitish fruit.

All these plants have certain characteristic features The flowers are diocious - that is, one plant bears stamin ate or male flowers only, the other pistillate or female] These flowers are very small, greenish-grey in colour, so

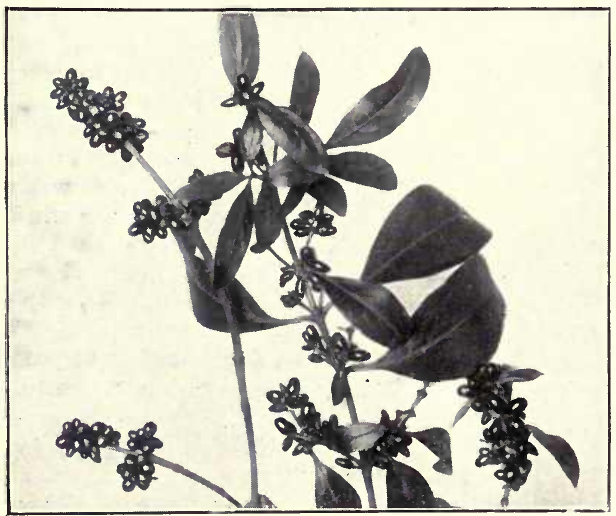

Coprosma Cunninghami in fruit.

that they are very difficult to see, and they are absolutely destitute of nectar. The staminate flowers are produced in immense numbers; they have each four anthers hanging ont of the tiny corolla cups on long slender filaments, so that they are easily shaken by the slightest breath of wind, and when so disturbed a cloud of extremely fine dry and dusty pollen is shaken out of them. The pistillate flowers are usually fewer in number and are produced closer to the branches. The most curious feature about them is the relatively large size of their stigmas, which are from eight 
to twelve times as long as the corollas. They therefore expose a large surface to the air so as to catch any pollen grains which may be floating about. Many persons seem to think that Coprosmas and similar plants which have inconspicuous flowers never blossom at all. This is not only want of observation, but something worse, which shall not be specified here; but it surprises me how commonly such an absurd idea is held.

Another plant which flowers thus early in the season is the large-leaved dark green Panax, sometimes called the New Zealand gum tree. The dull green flowers are produced in large compound umbels, and this makes them somewhat conspicuous. They are diøecious, but are certainly not fertilised by the wind, for they only produce a small quantity of pollen, which is not dry and dusty, and the stignus are rather small. They are fragrant, and produce a considerable quantity of nectar. Later in the season those flowers, which are then open, are visited by several species of insects, especially by a large brown hairy fly ; but at this early season the only visitor I have noticed is the bell-bird. The flat structure of the flower does not seem adapted to fertilisation by these birds, but they no doubt manage to lick up the nectar from the flat discs of the blossoms by their brush-like tongues, for they are often to be seen among the foliage.

A few other early flowers are to be found this month, such as the larger-flowered manuka, the bush lawyer (Rubus australis), and some others which I can only specify by their technical names; but most of them bloom more freely next month.

I will conclude this notice by reference to a very curious fungus which I have only found in August, and which occurs about Dunedin, but whether indigenous or introduced I cannot say. From its very peculiar shape it has received the name of Jew's Ear (Hirneola auricula$J u d(x)$. It is of gelatinous consistence, and is folded in a curious way. In a new country like this one of the missing features of interest in plants and many other things is that they have no history. But in Europe 
Hirneola had formerly quite a reputation for the cure of sore throats, and it was also used to apply eye-water to weak or inflamed eyes, and lotions to wounds, from its faculty of absorbing and holding water like a sponge. In the great International Exhibition held in London in

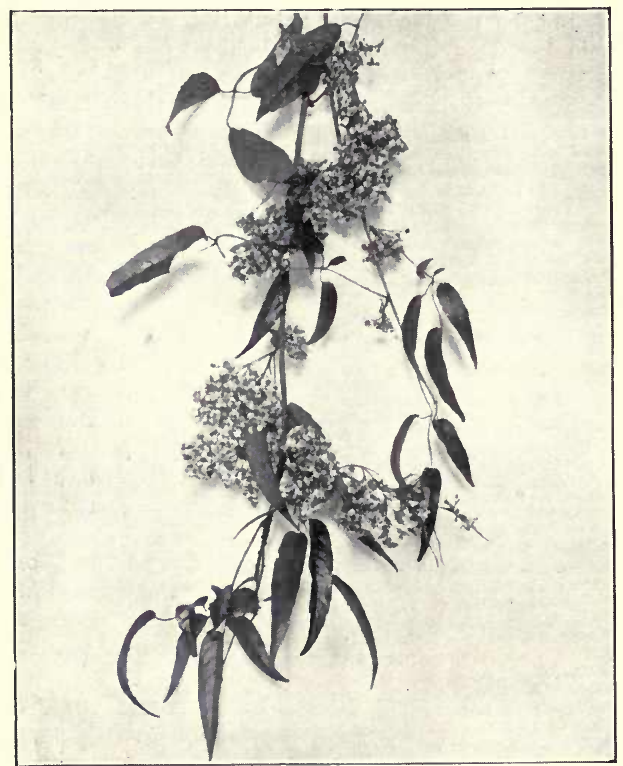

A Bush Lawyer or Bramble $\rightarrow$ Rubus australis-a slender-leaved form.

1862 a quantity of it appeared as a medicine exhibit from one of the French colonies-I forget which. The last time I saw it growing was two or three years ago, when the ground in front of the porch of the Girls' High School in Dowling Street was covered with it. 


\section{II.}

"There is a world in which we live with Nature-an enchanting world indeed to those who care for it. . . . There is a world of knowledge wrought by thought out of the long results of time, created by science out of the past and the present, out of the heaven above us and the earth beneath. Into these domains all may enter and walk therein with profit and with pleasure."

How singularly beautiful the snow was as it fell on Sunday the $23 r d$ of last month. The large soft flakes came down so thickly and so quietly in the still atmosphere, clinging with gentle persistence to every branch and twig and leaf till even the bare trees stood clear and sharp with gracefully feathered outlines, while the evergreens were borne down by the weight of their heavy burden.

The clear sky which followed the snow caused such a fall of temperature owing to unchecked radiation that everything froze up, the snow itself becoming like sand in its crisp dryness. It is not often the case in Dunedin that we have a snowfall which is not accompanied by an outbreak of snowballing among the juvenile population, but during the late severe weather the snow was mostly too dry to bind, and even when it did thaw a little during the day it was only to freeze again into masses of ice. What a stillness fell on all Nature? The week before the thrushes had been heralding the advent of spring, picking out the topmost branches of the trees and shrubs from which to pour out their joyous notes. But these suddenly ceased. and for over a week not a song bird was to be heard except a solitary bell bird, that could not keep silence so long, and that evidently thought something had gone wrong with the season.

After severe weather we count up our losses in the garden, and forget to count the gains. The losses are usually so conspicuous, and the gains we have to take a good deal on credit. In our gardens we grow many plants, natives of warmer regions, which will stand slight frosts, and we take our chance of their surviving the usual 
mild winter. But this season's frost has proved too much for many such, and the tender ones have suffered severely. Hydrangeas, Fuchsias, geraniums, and many others which usually stand through the year without protection, have been sorely marred. Very slight differences of position and exposure show interesting differences as to the action of frost on them. All flat and low-lying ground has much lower temperatures on clear nights than sloping ground has, from which the air as it is chilled tends to roll downwards. The result is that as a rule the hills round Dunedin feel the effects of frost far less than the flat does, and, in consequence of this, plants survive the winter. on the slopes of Roslyn and Mornington which succumb at the level of George street.

The severity of the late cold spell* is shown by the way in which native plants have suffered. A nost conspicuous, and also a most unexpected, case of damage is the way in which the young shoots and foliage of the common hina-hina (Melicytus ramifloms) have been shrivelled. It is evident that this is nearly the southern limit of the genus; this species ranges from Norfolk Island in the north to Stewart Island, but most of the others are found in the North Island. The poroporo has also been cut down badly in all exposed localities. Among North Island plants I find my karaka (Corynocarpus) has been killed back to the old wood. Several plants which grow along the coast, but which cannot grow in our inland Districts on account of frost, have been injured in Dunedin Gardens -e.g., the ngaio (Myopomum laetum), and even the common large and thick-leaved Senecio rotundifolius. Some of the smaller North Island plants have come off very badly ; a large clump of the white-flowered liliaceous Arthropodium has its foliage blanched and destroyed, though otherwise the plants have withstood the snow. The native Calceolaria is severely scotched, while all the outdoor specimens of the little creeping Fuchsia ( $F$. procumbens), which grows wild on the Great Barrier Island, are destroyed. 
Perluaps it is a more wonderful fact that plants escape damage by frost than that some suffer. When water freezes it undergoes such considerable expansion that it is liable to burst anything in which it is confined. This is well shown by the way in which our thinly tarred footpaths have been burst up in all directions by this winter's frost. If therefore the sap inside of plant cells becomes frozen the tissue is completely destroyed, as is often the case with the shoots of early potatoes, etc. But in plants there are several protective devices which prevent frost from doing the harm that we would expect. For one thing, the liquid in the plant cells is not pure water, but is a weak solution of various saline and other bodies in water. The addition of even a very small quantity of saline matter immediately lower's the freezing point of water very considerably. This is one safeguard. Again, the epidermal cells of plants are usually thickened externally, or, as it is technically called, are cuticularised, and cuticle is a substance of very low conducting power, preventing escape of heat in cold and increase of it in hot weather. Lastly, hairs are a most wonderful preservative against the chilling effects of frost, for not only are their cells usually full of air, but they often enclose and, as it were entangle, a layer of air, which is an excellent example of a body with very low powers of heat conduction. It is in some such ways that parts of plants which look fragile and delicate, such as the perianths of crocuses and snowdrops, and the young foliage of hyacinths and narcissi, remain fresh and unscotched through long continued frosty weather.

It is not always easy to know how much we gain by severe frosts. The most conspicuous benefit is the breaking down of the soil which it produces. How noticeable this is has been shown by the numerous clay banks which ornament so many of our Dunedin and suburban streets and roads. Heaps of debris lie along the foot of every such bank and the rains of spring will wash down a great deal more of it which at present is clinging to the bank face ready to be dislodged. This disintegration of the soil not 
only enables water and carbon dioxide to penetrate and attack the minerals forming it, but facilitates the movements of worms in it.

Another direct gain is the destruction of noxious insect life which follows severe frost, though this is probably usually over-estimated. Take the case of our commonest fruit-tree, the apple. Its worst enemies are the common woolly aphis and the mussel scale. In both cases it matters not whether all the old insects are killed off or not, the eggs are the all important means of propagating. If we lift one of the mussel-scales with the point of a penknife and examine the underside with the aid of a magnifying glass, we shatl find that it is merely an empty case covering from 50 to 100 eggs. The female insects are all dead and their shrivelled bodies may be seen inside the scale. But the eggs are all alive and no frost that is ever experienced in New Zealand affects them. In spring they will all hatch out as usual, and about November or December the young insects will probably be seen running over the twigs during their short period of activity,

But it is more wonderful how many large insects manage to survive low temperatures. Only the other day, after a continuance of frosty weather, a change of wind and brief rise of temperature bronght ont a fine large Vanessa butterfly, while in one of my rooms a small black wasp was flying about quite actively, having come in by the open window. The insects become torpid and sluggish with the cold-not necessarily, however, suffering the tortures which we imagine for them-and whenever they get a little warmth their faculties revive and out they come.

I do not remember a winter in which there has been such a scarcity of flowers as the present one. This is probably not due to the late severe weather, except to a small extent. The want of summer and autumn heat, and the very cold weather experienced throughout the greater part of May had probably more to do with checking vegetation than anything else. Meanwhile the recent cold will do no harm, but rather good, in retarding development, and we shall all the more enjoy the first general outburst of spring flowers. 


\section{III.}

What comes of so many of our birds during the winter season, and what causes them to migrate from one part of the country to another? No doubt the main cause of their movements is the abundance or scarcity of their food supply, but it shows how little we know of these questions, and now few persons keep any record of the facts of such cases, that so little information on the subject is available. Any mere effort of memory is not sufficiently trustworthy; what is wanted is a note of facts taken at the time. About thirty years ago, when living at the edge of a large bush in the Southland district, I used to keep a daily note of the birds which were met with, even the commonest. Though the record was broken on leaving the district to come to Dunedin, it was most interesting to look back on it in after years, and call up again the reminiscences of these early and rough days. I note, among other things, the total absence of the introduced species of birds which are now so common here. A few birds of various foreign kinds were liberated in this part of the colony before 1868, but it was in that and the following years that the Otago Acclimatisation Society did most of their work of introducing birds. Whether we ought to thank or anathematise the Society is still a matter of opinion.

So it was that when living at Mabel Bush, in Southland, we daily had the robins and tom-tits about the garden, while the pied and black fantails almost lived in the house, coming into the rooms to look for flies and spiders whenever the windows were open. We were awakened in the early mornings by the melodious concert of the tuis, horimakos, canaries, and other bush birds, singing their morning hymn. Kakas and wood pigeons abounded, and wekas used to dodge round the very doors in search of unconsidered trifles. The kakas used to tear the thatch off the stacks and let the rain in, and they and the parakeets were our chief enemies both in the cornfield and in the garden. At night the quaint cry of the moreporks was extremely common, and sometimes very eerie, as they called to each other from grove to grove. 
The very same conditions prevailed in Dunedin and its neighbourhood for many years after the founding of the settlement, but the whole aspect of the scene is now changed. The native birds with few exceptions have retired before the settlers and the new conditions which have been created, and we have now to go some distance afield to meet familiarly with these friends of our early colonial days.

As I write I hear the liquid call of a bell-bird, which loves to visit a Japanese Quince now in full flower under the study windows; but this solitary musician, and an occasional tom-tit or so, are the only native birds which have been seen in the garden for a long time past. Even the usually abundant wax-eyes seem to have sought fresh fields and pastures green. Now and again a tui is seen or heard in the Town Belt, lunt other species have been extremely rare or altogether absent. Of the introduced birds, the thrushes and blackbirds, starlings, and the ubiquitous sparrows, have been very much in evidence. But even the hedge sparrows have been rarer than usual, and the skylarks have seldom delighted us with their matin songs. The goldfinches, too, seem to have left us for a time. These absences may, of course, be only from Dunedin and its suburban gardens. The tuis and other native species may be common enongh at present in the bush districts, and the introduced birds may be keeping about the newly-plonghed ground in the farming districts, but they are certainly away from this neighbourhood.

When I first came to Dunedin, in 1871, there were a few introluced birds to be found here in the wild state, which have since then totally disappeared; and in subsequent years other's were liberated, which either disappeared at once or have since been lost sight of. A few of these cases are of special interest.

Thus, Indian mynhas * used to live abont Bell Hill, nesting on Dr Hocken's and other houses in that neighbourhood, and also on the First Church steeple after it was 
finished. They were also thriving in Christchurch about the same time. Their conspicuous colour and curious call made them "kenspeckle," (to use a very suggestive Scotch expression), but they have evidently been crowded out by the starlings, which have increased so remarkably in this their new home.

Between 1865 and 1869 the Otago Acclimatisation Society turnerl out about ninety Australian magpies, and these throve for a time, but eventually died ont also. Both in the neighbourhood of Dunedin and on Inchelutha they began to build and breed, but were mostly destroyed by lack of protection. The average so-called "sportsman," the man or boy who goes out with a gun to kill something, is an enemy to the naturalist and to all who love Nature and the things of Nature, and the wanton destruction of these handsome and very conspicuons birds was almost due to this class of people. 1 remember, in the early seventies, being out with a troop of High School boys on one of our Saturday rambles, when we had an encounter with a magpie. One lad in front of the party called out to those behind him to stop throwing things at him, as he affirmed that someone had hit him on the head either with a bit of stick or a sod. While we were looking in his direction, and denying indignantly that anyone had been guilty of such enormity as to shy any missile at another, a magpie suddenly swooped down from a neighbouring tree and hit the same lad a sharp blow on the head, knocking his cap off. And there, high up above us, was a nest, probably with eggs or young in it, and the male bird was taking this method of warning off intruders. Probably my presence protected the birds from molestation, but I can well imagine that had no restraining power been there that bold magpie's days would have been numbered. I never saw the birds in later years.

Why some birds should have increased so abundantly after being liberated, and others of somewhat similar habits should have either disappeared at once or died out in a few years, is a problem which we have no means of elucidating. We can only conjecture the causes. Thus in 1867 and the 


\section{54 A NEW ZEALAND NATURALIST'S CALENDAR.}

two following years the local Acclimatisation Society liberated twenty linnets and eight greenfinches, yet the former failed to establish themselves, while the greenfinches increased rapidly and are now extremely abundant in corn-growing districts, where they no doubt do much good during the year by keeping down insects, but run up a big debit balance when the grain is ripening by their wholesale attacks on it. Ten redpoles were introduced about the same time, and these birds are common in the East Coast districts, though they are almost never seen in the neighbourhood of towns. On the other hand, thirtythree chaffinches were set free, and these birds for a time became quite common, yet of late years they have been diminishing in numbers, and are now only to be met with occasionally. One still comes across a specimen, or hears their easily-recognised note now and again in Maori Hill, but I rarely see them elsewhere. Similarly, seven cirl buntings and eight yellow-hammer's were liberated here, and for a time they increased, but now they are not to be seen about town. The latter-named bird is still, I believe, one of those which occur among the grain-eaters in the Taieri and elsewhere, but the last cirl bunting I saw was on the Saddle Hill road some few years ago.

The local Society spent a good deal of money in the early days on other kinds of birds, which seem to have been introduced on no general principle except that those who suggested them knew them or of them in Australia or the Old Country. These were liberated in such small numbers that their chances of breeding were small, and naturally they were never heard of after the first few months. The mere enumeration of their names is interesting, and it will probably surprise many persons to know how many attempts at naturalisation of birds have failed. Here is the list:-Wonga-wonga Pigeons, 12; Bronze-wing Pigeons, 6; Laughing Jackass (Australian Kingfisher), 6; Australian Owls, 2; Australian Wax-bills, 4; Australian Land Rails, 2 ; Java Doves, 5 ; Mountain Sparrows, 2 ; Twites, ?; Reed Sparrows, 4; and probably some others. The most unaccountable failure in this work of naturalisation was in 
connection with the Robin Redbreast, of which forty were liberated in Fulton's Bush, near Outram, in 1885, and twenty in the following year. They were occasionally seen for a short time afterwards by the late Mr James Fulton, and in 1891 Mr A. C. Begg reported having seen one in his garden in Roslyn, but with these exceptions they never seem to have been observed. It would be interesting to learn whether anyone in the Outram or Maungatua districts has ever seen them since their liberation. The conditions seemed very favourable, but for some unexplained reason they have not succeeded in establishing themselves.

of large game-birds it is interesting to remember that twenty years ago pheasants were very common throughout the east and south of Otago, nearly two hundred having been liberated and their descendants having increased greatly. But the introduction of poisoned grain, which was to exterminate the rabbits, only reduced the pest but completely destroyed the imported game-birds. Partridges also used to be met with, one hundred and sixty having been set free. It was not an uncommon experience in walking over the hills between Brighton and the Taieri Plain to flush a covey of them : but they have disappeared along with the pheasants. Of this class of birds the only species which has held its ground, and that chiefly in the Peninsula and North Heads districts, is the Californian quail, probably because no poisoned grain is laid in these parts. But I do not know whether the bird now to be met with there is the common Californian quail, of which about one hundred and forty were liberated between 1868 and 1871, or the Mountain Quail, of which over one hundred and eighty were set free during 1881-82.

Of other game-birds, 12 Australian Quail, 21 English Wild Duck, 23 Guinea Fowls, 10 Australian Plovers, 8 Pintail Grouse, and 10 Black Game were also introduced, but disappeared almost as soon as they were set free.

One conspicuous success in acclimatisation is in connection with the Australian Black Swans. These birds, natives of West Australia, were set free to the number of over sixty, 


\section{56 A NEW ZEALAND NATURALIST'S CALENDAR.}

some thirty years ago, and they are now most abundant in the lakes and lagoons of the whole provincial district away down to Stewart Island in the south and Te Anau in the west. It is very common on a moonlight night to hear these birds calling to each other as they fly rapidly overhead on their journeys from water to water, and occasionally one can see them as they cross in front of the moon or between the observer and some bright part of the sky.

The history of acclimatisation in New Zealand has yet to be written, but it must be from a scientific, not from a mere popular point of view. 


\section{Chapter XI.-September.}

\section{I.}

CEPTEMBER is really the first month of spring in this D part of the world, and with its advent we feel that the long dead Winter has waned. The stir and hurry of life increase, the birds sing more blithely, the trees begin to burst into leaf, and "soft airs fan the hills."

Many native plants now come into flower, and some which have a short and fleeting season will not be met with again till next year-such as the delicate little purple orchids Corysanthes triloba and C. vivularis, which are to be met with in damp bush, and especially near creek beds, each with a curious spider-like flower sitting on a solitary heart-shaped leaf. On the Tomahawk Head one meets with Ramunculus acaulis, a very small stemless Buttercup which seems to send its little blossoms right out of the sandy soil on which it grows; and mixed with it is another almost inconspicuous herb, Claytonia australasica, with extremely thin-petalled white flowers and small creeping stems. One of the most interesting but rarest of our orchids, Sarcochilus adversus, also flowers this month. It used to grow in the bush at the bend of the Leith Valley near where the paper mill now stands, and this locality -now given up to bluestone-is where I first gathered it. It still occurs rarely on tree trunks in the bush along the west side of the harbour. An insignificant little plant with very small green flowers, so small that one would never suspect it required insects to fertilise them, it yet exhibits one of those remarkable devices to prevent self-fertilisation such as Darwin revealed to the curious in these matters. I remenber that when first I examined these flowers I thought that owing to their inconspicuous appearance they must certainly be self-fertilised ; but, besides being slightly 
fragrant, it was noticeable that a considerable quantity of nectar was secreted between the base of the column (which is made of the joined stamens and style) and the fleshy lip of the flower, and this caused me to look more closely into their structure. The four bundles of pollen are united into two almost globular masses, which are attached by a band to a broad flat disc. If this is removed from the anther, which is at the top of the column, it at once commences to contract, and thus causes the pollen masses to be depressed to a nearly horizontal position. In Darwin's Fertilisation

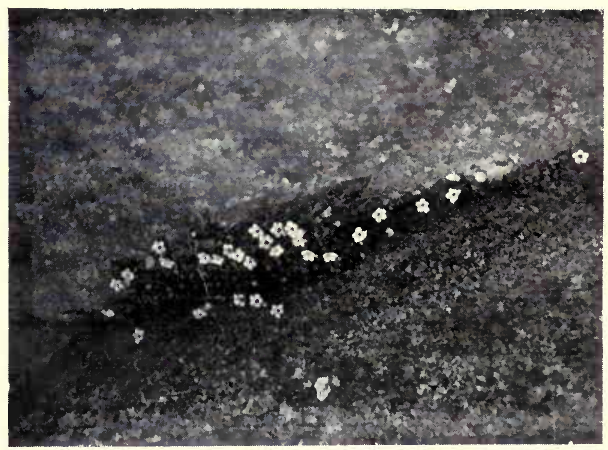

Claytonia australasica.

of Orchids will be found an account of a similar structure in the British Orchis mascula. The time taken by this movement in our species is about 10 seconds. If the pollinia were attached to the proboscis of a small insect, they would on their first withdrawal from the anther be in such a position as to strike a similar portion of the next flower visited; but this is obviated by the depression of their stalk, so that in the short interval of time mentioned they are so placed as to project into the deep and slightly two-lobed cavity of the stigma. If one watches bees 
visiting flowers they will be seen to enter several blossoms in 10 seconds ; but flies, which probably do the work here, are much slower in their movements, and hence probably the time is quite sufficient.

It is one of the puzzles to students of New Zealand botany why so many of the indigenous flowers of these islands are imperfect. There are very many which exhibit complete separation of the reproductive whorls, while in others, where there is not this complete separation, yet there appear to be physiological barriers which are quite as effective. For example, the Fuchsia, which is coming freely into flower this month, shows two (sometimes three) distinct kinds of flowers. The large common form has flowers of an inch or more in length, and these have all the parts present - eight stamens with well-developed anthers full of blue pollen, and a large very viscid stigma to which these pollen grains adhere. Whether these flowers can be fertilised with their own pollen or not I do not know. The only way to ascertain the fact would be to experiment upon them, and I do not think this has ever been done. But besides these flowers others will be found, on different plants however, which are not half as big; they are pale and pink in colour, while their anthers are small and nearly white and contain no pollen. Functionally these flowers are pistillate or female, though the parts of the staminal whorl are all present, and certainly they cannot bear fruit unless pollen is brought to them from the other kind. This could also, of course, be proved experimentally : it only wants a little time and trouble to do it.

The why and the wherefore of this sexual separation has not been explained yet. Our two common kinds of mapau (Pittosporum engenioides and P. tenuifolium) are to be found in flower this month. The former, or white mapau, has fragrant yellowish flowers in conspicuous clusters, and in between the bases of the stamens and the ovary there are little beads of nectar, so that the blossoms are evidently meant for insect visitation. In the northern parts of New 
Zealand these flowers are usually diøcious, while here they possess both stamens and pistil. Yet though structurally hermaphrodite, they are functionally unisexual, and I do not think they can set seed without the intervention of insects. The black mapau ( $P$. tenuifolium) has always, apparently, perfect flowers, yet it is probably quite incapable of self-fertilisation; its near ally, $P$. Buchanani, from the North Island, certainly is. The black mapau differs remarkably from the white in having much larger solitary flowers, which are bright reddish purple when they first open but which become very dark before withering. They also possess the nectar beads, but are not apparently fragrant. The difficulty in ascertaining how these flowers were formerly fertilised is that so many of the native insects which used to do this work are now nearly exterminated by introduced birds, so that the original conditions have been very much altered. I have no record of any insects observed on them except hive-bees.

One of our commonest mistletoes, Tupeia antarctica, a leafy parasite of a rather pale green colour, flowers this month. Its flowers are yellowish-green in colour and are completely diocious, the staminate and pistillate forms being found on different plants. Though so inconspicuous they are very fragrant, and secrete a large amount of nectar. I have noticed that they are inuch frequented by midge-like flies, which in sucking the nectar from the flat dises of the blossoms bring the lower part of their bodies into contact with the stamens and stigmas.

While still too early for most native flowers, the following are to be met with in September:--Melicytus lanceolatus, a large-leaved kind of hina-hina, still common enough in the West Taieri bush and formerly to be met with in the wooded gully of the Wakari Creek passing through the golf links. It differs from the common hina-hina, which flowers later in the season, in being functionally diœcious. Astelia nervosa, a common liliaceous plant in the bush, 
also functionally diœcious and having green fragrant flowers almost buried among the large flag-like leaves. They are fertilised by flies. The bush lawyer (Rubus australis) also begins to flower in September. There are several varieties, of which one or two probably deserve to

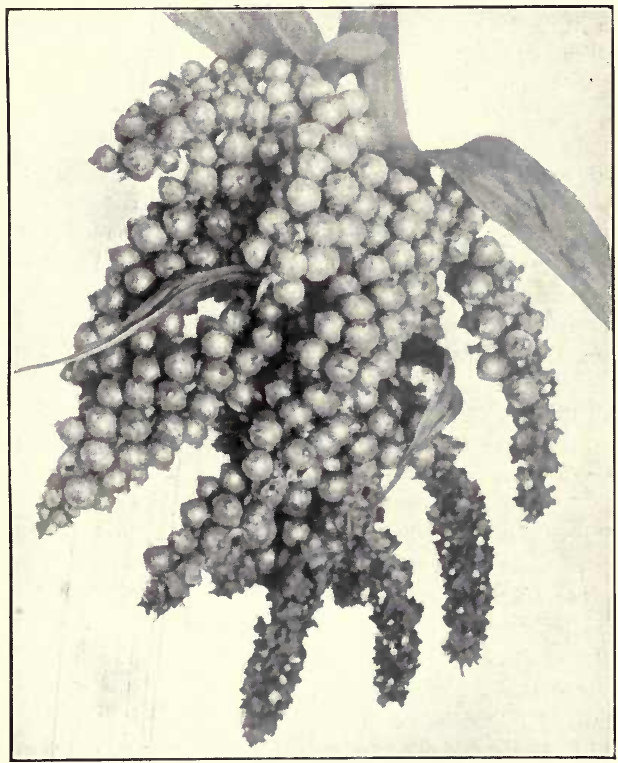

Astelia nervosa in fruit.

rank as distinct species. The commonest form is strictly dicecious, so that cross-fertilisation is a necessity. They are visited for their nectar and pollen chiefly by small beetles of several species, and if you want to observe them, hold a sheet of paper under a bunch of the flowers and get 
someone to give the branch a smart tap with a stick, when scores of the little insects will drop on to the paper. I have gathered eight species of beetles on these flower's, and have also noticed several species of native flies, large and small. In Otago Central I have met with staminate forms of Rubus tending to become double: I do not know whether the form is common. Tutu, manuka, and ngaio in flower are occasionally to be met with this month.

The present season (1901) is late owing to the severity of the winter, so that many deciduous-leaved plants which are usually in leaf by the commencement of September have hardly yet begun to show swelling of the leaf-buds. This is not an evil, for mild winters followed by cold springs do far more damage to vegetation. While thus delaying vegetation the lateness of the season seems to make little or no appreciable difference to the breeding season of the birds, and several of the native species nest this month.

In all bush districts which are not too near the abodes of men, under the shelter of a tree fern, in a bunch of Parsonsia, or in the friendly shade of a mass of native bramble, we may now meet with the large loose nest of the tui. The walls are often intertwined with moss or fibres among the slender twigs and stems of which it is constructed, with brown fern-scales shining through them, while in its evenly hollowed cavity on a lining of fine grass three or four delicately-marked eggs are laid. Their colour is nearly always pink spotted with darker red, or, if white, they are streaked and marked with pink and red. They are fairly large eggs-over an inch in length. I do not think that many tuis nest within the Town Belt of Dunedin now, though they visit it for the native Fuchsia which abounds there, and are very fond of eucalyptus blossoms, but they are common enough in the neighbourhood of the town. They are most pugnacious birds and are able to hold their own against any of their bush 
neighbouxs or of the introduced species. The long-tailed cuckoo seems to be one of their pet aversions, and when these birds arrive, later in the season, the tuis frequently advertise the fact and give them a severe hackling.

The korimako is one of our commonest native birds and is a frequent visitor in town gardens. It builds, somewhat later in the spring, in similar situations to the tui, usually at no great height from the gromd, and its nest is nearly always lined with feathers which are often selected apparently for their bright colours. The eggs are generally four in number, smaller than the tui's, and of a white or pink colour marked with streaks, dots, or blotches of red or purple.

Down both sides of the harbour and in all similar localities the kingfisher (Halcyon vagans) is still commonly to be met with. It is one of the most beautifully plumaged birds in New Zealand, but is very shy of men. It always makes its nest in the extremity of a sloping-up tunnel, which it excavates in a bank or near a decaying tree or even in an old sod fence. The tunnel is quite narrow, and from a foot to a foot and a-half long, and in the little chamber at the upper end the bird lays from five to seven rather large glossy white crgs.

One more of our delightful native birds, which unfortunately has disappeared from the neighbourhood of settlement - a victim to its habits of trustfulness, - is the native robin, and this bird commences honsekeeping in the month of September. Mr Potts, whom I have quoted before as an observant naturalist, writes very fully of its nesting habits, and with this quotation I shall close this note:- "The nest is often placed amongst the steeplyridged roots of a mighty tree near a creek, or on a bossy protuberance on the rugged stem, or perhaps it may be observed neatly filling a hollow, matching so well the moss-tinted russet-brown bark with its cleverly selected material that it is difficult for the eye to detect the robin's home. Amongst the different kinds of material that are so 
judiciously chosen may be found moss, roots, hair-like scales of Dicksonia, or the darker scales of Hemitelia and Cyathea (should those beautiful tree-ferns grow near), dead leaves, fine grasses, slender sprays, webs, sometimes a few feathers, on a broad foundation of thick coarse moss. The structure is raised by the careful entwining of the material till, with a sloping front, the nest measures across the top some five or six inches. The cup has a diameter of three inches, while its depth is from an inch and a-quarter to nearly two inches. The eggs vary in number from two to four." They are usually white or creamy in colour, and marked with grey, purple, or brown.

\section{II.}

In connection with the introduction and acclimatisation of all animals in a new land, there is a subject which merits and will well repay investigation-namely, to observe whether they undergo any change themselves under their altered conditions, or cause the indigenous fauna and flora to alter in any way. Leaving out of account the tremendous alteration which has taken place in the insect fauna by the introduction of so many kinds of insectivorous birds - for the subject is too vast and too imperfectly studied to generalise upon-I may point out that so far very little, if any, alteration has yet been observed either in the birds themselves or in their habits. Yet it is probable that such will take place in course of time, and records of them should be made as they occur. Even odd and isolated cases are worthy of being noted. Thus an amusing instance was narrated to me the other day of a tui which was heard in the Town Belt successfully mimicking the song of a thrush on a neighbouring tree. The tui is a noted minic, and seems to take delight in imitating the notes of other birds, and when caged is a very apt learner. The bird I refer to here has been noticed by at least two observers, so that I think there can be no mistake about the facts. Well do I remember a splendid tui which belonged to a Dunedin lady, which used to take delight in barking like a dog at visitors, and then cooeing 
to them as they went away. I was once walking from the house to the gate, when a gentle but persistent coo-ey caused me to turn back to see who wanted me; as soon as the bird saw me coming near the house he began to bark. I did not tumble to the fact, as the Yankees call it, that both sounds came from the same throat, and thinking I had made some mistake went off again once more towards the gate, when at once the rascal began to coo-ey. His actions struck me as very much like a case of reasoning.

When one notices something new to them in the habits of one of the introduced birds, they are apt to think that it is a case due to changed conditions, but such an inference is by no means a safe one. So, in recording one or two which have come under my own notice, or been described to me, it must be borne in mind that change of habit may occur in individuals without becoming at all hereditary. Thus ow skylarks do not always sing on the wing only, as they are credited with doing. They often continue their song even after coming down to the ground, or will sometimes alight on a post and sing. In Europe these birds never alight near their nest, but always at a distance from it, running along to it under cover when they have satisfied themselves that there are no watchers about. Here, with almost no enemies to guard against, it is just possible that their cautious habits might be relaxed to a considerable extent.

Thrushes occasionally sing on the ground (one sometimes doing so on my lawn), or even on a telegraph wire. But there is a most remarkable case-perhaps known to many whose business takes them near the railway stationof one which sits on a chimney-stack on one of the high buildings in the Dunedin Triangle, from whence he pipes his morning song. He is often flecked with soot but evidently does not mind it, resuming his perch each morning. Probably his mate is in one of the bushes down in the shrubbery on the other side of the wide roadway.

It is a common occurence to notice a tui fly from its 
momentary perch on a tree to pussue a moth or a butterfly in the open, and the rapid twists and turns of both pursuer and pursued, the sudden downward swoop of the bird, and the equally rapid side dash of the insect, show that both enter into the struggle very keenly. I have not unfrequently noticed sparrows similarly engaged, and where their prey was some slow-flying moth they were able to secure it, even thongh their movements lacked the flashing rapidity of those of the tui. It would be interesting to learn whether sparrows hawk for moths in the Old Country. I can find no record of the fact, though it may be well enough known.

In this country sparrows build in all sorts of placesamong others they are foud of cliffs, especially of deep clay banks. Thus, in railway and roadside cuttings, especially where these are fissured by water channels, they are fond of burrowing and of picking out holes in which to make their nests. I can well remember, in my old Country days, how various birds used to build on the cliffs abont Arthur's Seat in Edinburgh, and on the sides of the Castle rock. But the sparrows in such localities were not the common birds. Swifts, stonechats, winchats, and, on the more precipitous and inaccessible parts, various kinds of hawks and other birds of prey were the chief occupiers; while on sand cliffs and quarries we used to see numbers of the long narrow burrows of the sand-martins. But in New Zealand the sparrow utilises all such localities; he is the most accommodating of birds in his habits, and his motto seems to be "I fear no foe." In the limestone country behind Oamaru pigeons had formerly taken up their quarters in various parts of the cliffs, but of late years they have been dispossessed by hordes of starlings and sparrows.

The almost total absence here of enemies may be expected to lead in time to modifications of colour in the birds. Or perhaps it would be more scientifically correct to say, to prevent the suppression of such modifications when they arise. Colour sports are very common, but under the severe conditions which prevail in Europe they are rigorously suppressed. There a white or piebald 
thrush or sparrow has very little chance of coming to maturity, for its change of colour renders it especially conspicuous to its enemies, and it is harried continually and eventually destroyed. But in this favoured land if the young bird escapes the attention of that most destructive animal the small boy, its only enemies are those of its own kind. Apparently these are often formidable enough, for there is no such thing as fashion in Nature, and a thrush which develops a white wing or a white-striped tail, instead of being admired by all other thrushes, is treated more or less as an anomaly - as having transgressed the laws of proper and sober thrush colouring, and is liable to be treated with contumely. The fable of the fox without a tail appear's to receive a great deal of exemplification among the higher animals, and the harsh treatment often meted out to what are known as "sports" in a state of Nature is probably one of the devices whereby specific characters are safeguarded from indiscriminate variation. I formerly collected a good deal of information about such sports among our introduced birds, and found that while they were fairly common yet they did not tend to increase much, except in special localities. For several years there used to be broods of thrushes in the Town Belt and gardens at the foot of Littlebourne which had either white wings or tail, or both, but I saw none last season. Mr R. M. Laing has told me that in one portion of Christchurch white-feathered and very light-coloured sparrows were becoming common. This was several years ago, and if such sports are anywhere tending to become permanent an interval of a few years would give them time to assume a marked character. I have always noticed that such conspicuously-coloured birds were unusually wild and shy, their markings making them objects of undesirable attention to various kinds of bipeds.

This fact of colour-variations among birds tending to be so constantly eliminated may account for the uniformity of colour which characterises the individuals of the various species. In the case of rabbits there appears to be no repression of the tendency to vary, nothing to repress the 
colour sports which arise. In Europe any rabbit which departs from the normal colour becomes more or less markedly conspicuous to its numerous enemies. Among birds there are falcons, hawks, ravens, carrion crows, \&c., by day, and owls by night, to pursue them; while foxes, stoats, and weasels prey on them constantly. The slightest departure, therefore, from the dull gray in the colour of their fur renders them more easily seen, and thus such sports are constantly weeded out. But in New Zealand there are very few enemies except man (an enemy against whom natural selection is almost powerless), and in consequence variously coloured rabbits - black, buff, and white-are not rigidly suppressed. I was particularly struck with this fact the last time I was in the Wanaka district-fancy-coloured rabbits seemed to be almost as common as the greys.

In pondering all such questions there are, of comrse, other considerations to be taken into account besides the single one of the enemies of the species. Perhaps grey rabbits, as the most rigidly-selected form, are more hardy or more fertile than other varieties-we cannot tell ; all we know is that our ignorance on such points is colossal, and that we are apt to generalise on very insufficient data.

If a Rip Van Winkle among naturalists could arise here, one who had known the natural conditions in 1849, and if he could be dropped down in Dunedin now, he would be astounded at the changes which have taken place during the interval in the aspect of Nature. A very large proportion of the indigenous flora and fauna has disappeared. The ferns and other delicate plants which formerly filled the bush are nearly all gone-dried up and exterminated. The big trees have disappeared long ago. The undergrowth consists very largely of European plants, the birds are those of the old land, the whole face of Nature is altered. I felt this very distinctly the other evening when walking up a narrow valley ainong our southern hills. The hillsides were ablaze with the golden bloom of the gorse, and the air was heavy with its fragrance. As the sun went down behind the western uplands lying beyond Lake Waihola 
the air became vocal with the songs of the thrushes. Everything, except the tussocks and the blue gums, suggested a valley among the hills of old Scotland. Long after the stars were peeping out, and even when the half moon was throwing my shadow strongly on the road before me, the melody was still kept up. Gradually it died out, and one belated bird came flying down the valley, and as it passed overhead it poured out a stream of song-surely another new habit for a thrush, learned in this land of changed conditions. 


\section{Chapter XII.-October.}

I.

THE early settlers in this colony greatly missed - that is, 1 those who had eyes for such things - the change of the seasous which marked the year in the land of their birth, and which helped so greatly to diversify their life in the old home. They noticed here that the weather got colder as the Autumn waned and the Winter came on, and again as the days lengthened there was the gradual increase in warmth; but the erratic nature of our climate, which often gives us an Indian summer in mid-winter and then freezes us up in the middle or end of spring, took away from the sharpness of the impression, and Nature lielped but little to deepen it. The native bush does grow duller in its sombre green as the old leaves lose their freshness, and on the other hand some of the trees put on a fresh flush of foliage as the sun's rays come more directly down on them; but old New Zealand shows little signs of a real spring time. The deeper bush is just about as beantiful in mid-winter as in Summer, the ferns and mosses are nearly as fresh and green. The chief difference is that the groumd is wetter and colder. But as cultivation and tree planting have spread in this new land, and as gardens have been increased, so the signs of the seasons are becoming more marked, and with this change there comes a greater diversity in our views and aspects of life. It is said to be one of the charms of American rural life that the changes of the seasons are so sharply marked, and it is equally one of the drawbacks of a residence in the tropics that the monotony even of its luxuriant vegetation palls on the senses.

This fact of an increasingly well-marked Spring season has come home to many of us during the fine weather which prevailed during the greater part of last month. It has 
been rendered increasingly patent by the number and beauty of the spring flowers - especially the narcissi and primroses - which have brightened our borders for some weeks past, by the white tresses of our orchard trees now brightening into a pink flush as the apple blossoms are opening, and by the varying hues of green which have been displayed by the unfolding foliage of the trees and hedgerows. The development of bud and leaf is beantifully exemplified in the introduced decidnous trees, and it is wonderful to note the protective devices of the various species, and the economy of space in many a bud in which the young leaves are being quietly folded close together waiting the advent of the warmer weather and the longer days. Lubbock has published a book on Buds and Stipules, and it is worth anyone's while who has sufficient interest in the subject, and who will take the time to do so (and who has not the time, unless it be the person who has nothing to do?), to examine those examples quoted by him, which are now to be commonly found here. The ash and lilac, with their scale-like outer leaves covering their now-opened winter buds; the maple leaves, covered by the former leaf stalks; the beech, oak, elm, poplar, and chestnut, with their covering stipules; the horse chestnut buds, with their coating of gummy secretion and hairthese and many others are to be met with, and now is the time to see their unfolding.

The native bush shows but little of this diversity. The same causes which have given us an evergreen vegetationthe comparatively equable climate and the derivation of most of our trees from those of warmer zones-have tended to produce simplicity of bud structure. Here the need of protection during a severe winter season is not universally felt as in the northern hemisphere. Most of our trees and bushes grow together and mutually protect one another. 'Their thick foliage and branches prevent radiation and consequent cooling of the surface of the earth, and thus, while the buds on the lower branches are protected by those above, those on the upper branches are out of the range of all but very hard frosts. So it comes about that 


\section{A NEW ZEALAND NATURALIST'S CALENDAR.}

only a few of our native plants have their buds specially protected. The mapaus, black and white, are now unfolding their long slender buds, covered by brown-edged scale leaves, which increase in size from the outermost till we come to the fully-formed leaves on the opened branches. The white mapau has had its fragrant clusters of yellow flowers open for two or three weeks, while the black is now putting forth its solitary brownish-purple flowers. The Panax, too-sometimes named the New Zealand gum tree -has its buds protected, but in these it is the dark purple sheaths of the old leaf-stalks which cover the delicate young blades. How closely packed these young leaflets are! When so young they are soft and flaccid, but they thicken and harden with age, and then the frost touches them not. The hina-hina is now beginning to bud again after its recent sharp defoliation, but its buds have no special protection; the young leaves have their two edges just rolled in towarls each other. The pepper trees simply have their young leaves folded together; the veronicas and coprosmas cover each pair of young leaves by the preceding pair. These and many other plants testify by various details of their structure to the fact that the struggle for existence in these islands has not been so keen as it has been in the widespread lands of the northern hemisphere. Here in past days there has been no glacial epoch to drive our plants into nearer proximity to the tropics. The conclusions of the geologists-drawn from a consideration of the plants and animals which formerly flourished here and left their remains in our sedimentary rocks-are that this country at the time of the development of its present flora was on the whole warmer than it now is, and that its plants had mostly a sub-tropical or warm-temperate character. The Nikau Palm is now placed in the genus Rhopalostylis, but was formerly known as Areca sapida. The southern spread of the palms of the genus Areca, which still maintain a slight foothold in Banks Peninsula, the occurrence of Hakea or some closely-allied form of Proteaceous plant in the lacustrine clays of St Bathans, and many similar facts, all point 
in the sane direction. Our climate has probably got very gradually colder during recent ages. If anyone fears the gradual coming on of a cold epoch, they may comfort themselves with the fact that it will not refrigerate them dming their time, and they may further remember that the dominant races, not only of plants, but especially of men, have come out of the cool regions of the earth.

This year (1901) the season is considerably behind its usual time-on the average, I think, quite a fortnight. It is difficult to assign general dates for the unfolding of buds and flowers. The only way to arrive at a true estimate of the earliness or backwardness of a season is to keep a record of the plants in one locality. Thus the hedgerows and deciduous trees growing on the summit of the ridge at Roslyn are at an elevation of over 600 feet above those in the Botanical Gardens, and it would be valueless to compare the two localities. Again, those on a slope with a northern exposure are often weeks earlier than those facing south. But taking an average from my own garden and the surrounding neighbourhood, I find the thorn hedges, plum and pear trees, and the gorse bushes are fully a fortnight behind their usual time of coming out.

The absence of a well-marked season of arrival of life and growth would soon make itself felt in the literature of the land, for the spring charms us not only because it restores Nature after the rest and sleep of winter, but because also it is the time of reproductive activity. It is the season of blossom, when tree and bush and humble herb break out into flower, offering their stores of nectar and pollen in their temptingly-coloured and fragrant envelopes to their insect auxiliaries. It is the season when the birds awake their song, and when their efforts to charm their mates vender the groves vocal. It is the season which has called forth much of the sweetest raptures of the poets :-

"In the spring a fuller crimson comes upon the robin's breast, In the spring the wanton lapwing gets himself another crest, In the spring a livelier iris changes on the burnish'd dove, In the spring a young man's fancy lightly turns to thoughts of love. 
Now, apart from the altered forms of life to be met with, even a Tennyson conld not have written those lines in New Zealand. I am not referring to the young men and their fancies, but to the lack of a marked spring season. The introduction of so many European forms of life tends to remove this impression. And thus, while regretting the disappearance of much that is unique and umreplaceable when our native vegetation disappears before the "improving" hand of man, we should yet welcome the sweet change which transforms the face of the country and brings to us promise of the season of summer fruits and harvest bounties.

\section{II.}

It is a common subject of remark this spring that the season is a late one. After so mild a winter-for since June there was no frost worth speaking of - it might have been expected that all plant life would have sprung more rapidly into activity, and that the foliage and the blossom would have developed mich earlier than has actually been the case. That this has not taken place would seem to show that the cold of winter has little or no retarding action on vegetation, or perhaps, to state it more accurately, that the development of plant life in spring is scarcely dependent upon the winter climate at all. When the foliage is fully developed then lack of heat tells on plants at once. Their function is to use up, as food material, as much carbon dioxide as they can assimilate, and to store up the carbon in the form of starch, sugar, gum, or other similar substance. This they do under the influence of sun's light and heat alone. If these are wanting or are deficient in quantity the plant cannot store up the same amount of reserve. Thus if cold and sunless weather prevails during the growing season of the year the growth of the following season is retarded, and will appear later than usual, as the store of reserve material from which the new leaves and flowers are to be produced is not sufficient. Our late spring, then, is due primarily to the absence of heat during last summer and autumn, so that the plants 
were not able to fully develop their buds before the season's growth was arrested. Should we have a warm summer this season the following spring will be an early one, however' severe and cold the winter may be.

These remarks apply only to plants whose duration of life is longer than one year. Annuals make no store of food material, except such as they lay up in their seeds, and in consequence their gelmination is affected directly by the conditions of warmth and moisture which prevail. I do not find, for example, that my crop of chickweed $o r$ of bitter cress is any later of dereloping this year than it was last season--indeed it seems to be more luxuriant and vigorous than ever; but that is only the usual appearance which the persistent weeds of a garden present to us as we face them afresh with the vain determination to exterminate them.

Innumerable matter's of interest meet us in the garden at this time of year: this question of annual plants is one of them. To many amateur gardeners the sowing of a few patches of anmuals is the principal operation of the year, and it is worth while to consider where these flowering plants come from, and, if possible, why they have such a short span of life.

There appear to be two modes in which the annual habit of certain plants has arisen, or rather, perhaps, we might say, two causes which have led to the production of annual plants. The first is the occurrence of a cold season during which growth is nearly or quite arrested. Many plants, therefore, have adapted themselves to the conditions which prevail in the cold temperate zones by becoming annual; they grow, flower, and produce seed during the warmer portion of the year, the seed lies dormant during the cold season and germinates on the return of longer days and warmer weather.

It is surprising what a number of our common weeds of cultivation belong to this section. In my garden and lawn there are some thirty-six kinds of weeds (not more than other people's, however), and of these twenty-one are ammal or live less than a year. It must be a great 
advantage to a plant in its warfare with man, or rather in the mode in which it utilises his labours in stirring the soil, to be able to grow to maturity and to scatter its seeds in a very short period of time. In the world of Nature it is not the individual which is the important unit, it is the race, and those plants and animals which most rapidly come to maturity and reproduce their kind in vast numbers in a limited period of time are the forms which become the most abundant and dominant. Indeed, it is this annual habit and rapid individual development which causes these plants to be such troublesome weeds.

The second class of annuals come from lands where they are subjected to a warm climate, and especially to a dry season, when all vegetation which is not deep-rooted tends to be killed off by drought. Such plants in their native habitats germinate with the moisture of spring, rapidly come to maturity, bear flowers and fruit in the early summer, and scatter their seeds before the ground becomes completely parched. To this class belong many of our cultivated annual flowers, especially those which we call half-hardy, and which have been raked together from distant parts of the earth. Thus Phlox Drummondi from Texas, Zinnias from Mexico and Peru, Saponaria from Southern Spain, and many other genera and species, are all short-lived plants in their native countries, living out their short gay life in the earlier months of the year. In this part of New Zealand, with its moist and equable climate (which it really is, though we sometimes seem to get summer and winter in the same day), many of these plants have a pretty long lease of life, but few of them survive into the second year.

A very interesting period in plant life, and one which is very easy of study at this time of year, is the germination of the seed. It is worth while watching some of these as they come up in the seed beds, and noting the curious differences which they present. And if one will take the trouble to soak a few seeds, such as those of beans and peas, radish and cress, lay them on the surface of damp soil in a pot and cover them so as to keep their moisture 
from evaporating, various details in the process of germination may be noted.

The first portion of the seed which developes is the rudimentary root or radicle, which bursts out of the enveloping skin and turns downwards to penetrate the soil. It is essential that this should be the first organ produced, because by it the future plant is to be attached to the ground and also the nutriment required by the growing plant is to be absorbed by it. After a time a fine dense felt of most delicate white hair appears towards the growing end of the radicle, and it is through these extremely slender closed tubes that the water filters into the tissues of the plant. Plants have been designated synthetic organisms, in contradistinction to animals which are analytic organisms, for the former feed on water and salts dissolved in it and on carbon dioxide, and from these simple materials they build up their very complex tissues, while animals feed on the highly organised substances produced by plants in the first instance, or by other animals, and reduce them to water and carbon dioxide. All the absorbing parts of roots are covered with these root hairs, but it is not easy to see them unless by growing seeds under the conditions suggested, when they are readily studied.

After the radicle has elongated into the soil the seedleaves open out. In regard to all the four plants named by ne, it is interesting to notice that in the adults the leaves are alternate in their arrangements-that is, they are produced singly along the stem, while these first seedleaves are produced in a pair opposite one another. In peas and beans these first leaves do not fulfil the functions of ordinary leaves - that is, absorb carbon dioxide and build up new tissues with evolution of oxygen; they act only as reservoirs of nutritive materials and yield up to the young growing plant the concentrated food stuff which is stored in them. It must be remembered that the seed is not strictly the new plant or the new generation, though it always contains the embryo. The seed is really a stage in the development of the new generation, when its activities 


\section{I78 A NEW ZEALAND NATURALIST'S CALENDAR.}

become dormant for a time in order that the individuals may be distributed. Nearly all plants are fixed organisms, but in order that the race may be distributed, so that individuals of the same kind may enter as little as possible into competition with each other, there must be some stage or period of their life when the organism can be carried hither and thither without injury. This is the stage represented by the seed. The embryo is developed while it is still in the parent plant, and the extent to which its development is carried in the seed is extremely varied. Thus in the parsnip the embryo is only slightly developed, and a relatively large quantity of food material has to be stored up beside it to feed it when germination commences, until it can produce its own root and leaves. So a parsnip, as every gardener knows, takes some six weeks to show its leaves above ground after the seeds are sown. A pea, on the other hand, is all embryo, and it only takes a short time to show its point above the soil; but its first leaves are only store organs and do not rise above the surface. Lastly, a radish or similar crucifer is most highly developed of all; its leaves are folded up in the seed, are already green and prepared at once to enter on the work of digestion of the food, so that as soon as the radicle has penetrated the soil the young plant lifts these two leaves into the air and the light. It is therefore only the question of a few days between the sowing and the springing of the seed of the radish. These three common plants well illustrate the differences of degree of development shown by seeds.

\section{III.}

Late as the present season is-and it is about three or four weeks behind the average of the past two decadesflowers begin to be more abundant, and with the lengthening of the days it is more easy to find opportunities to examine them. Indeed, objects of interest in both the animal and vegetable world now crowd upon the attention of the lover of nature, and the difficulty is not what to look for but what to select for observation. 
Both species of Clematis come now into flower. There are considered to be five species in the immediate neighbourhood of Dunedin, but for any but botanical specialists we may confine our attention to the large white form C. indivist and the fragrant yellowish kind misnamed by Raoul Clematis foetida. All the New Zealand species of Clematis have flowers which are strictly dioecions in function-that is, one set of plants bears male and the other set female flowers. Thus, while the large male flowers have only a great tuft of stamens and no carpels,

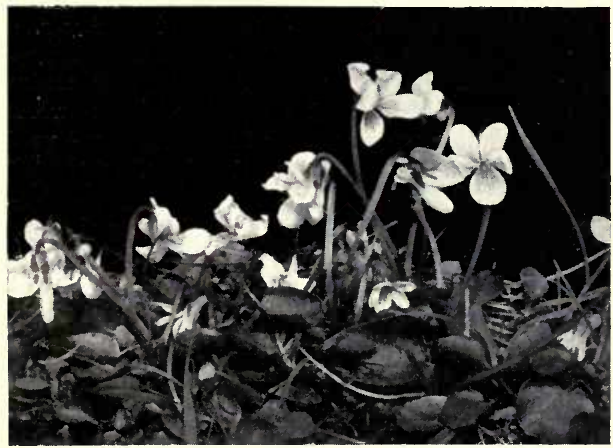

Native Violets-Viola Cunninghamii.

the female flowers have a central mass of carpels surrounded by a row of stamens, but the latter are functionless, having no pollen in their anthers. This sort of incomplete structure is not at all uncommon in New Zealand flowers. The large white Clematis is scentless and destitute of nectar; the smaller yellow one is very fragrant, but I do not think it has any nectar. Both are visited for the sake of the large quantity of pollen which they produce. Clematis resembles Anemone in having petaloid (that is, brightly coloured) sepals but no petals, and also in the fact that the style grows after the flower 
has withered, and acts as a means of distributing the seed through the agency of the wind. By the way, I think that the usual pronunciation of Clematis is not correct; the "a" should be short, not long, as the word is derived from the Greek "Klema," a vine shoot. There is no absolute rule in these cases, but I take it that without being pedantic the pronunciation should as far as possible follow the derivation.

Both the native violets* begin to flower in October. Both are white-flowered, with streaks of blue or purple on the lower petal, these lines acting as honey-guides to the small insects which probably fertilise the flowers. Our native violets have a character which is common to most plants of the genus-that, namely, of producing later in the season a second set of imperfect flowers; so that if the ordinary conspicuous blossoms do not produce seed these later ones, which are closed and self-fertilised, may do so.

The common ribbon-wood (Plagianthus betulinus) gets its specific name from its general resemblance to the birch (Betula) in habit and size of leaves. I have been struck with a peculiar feature which characterises two young trees in my own garden. They have been quite deciduous for the last three or four years; but the interesting thing is that their foliage when they were very young was that of the closely allied genus Hoheria. It is only of late years that they have begun to develop the true Plagianthus leaves, and this only in their upper branches. Indeed, I planted them as young Hoherias and did not find out my mistake for some years. The flower's of this plant are very small, but are crowded into dense panicles. The sexes are quite separate in different trees, but from the fact that the flowers are very fragrant and contain nectar they must be visited and crossed by insects.

Round the shores of the Harbour may be found specimens of another Plagianthus ( $P$. divaricatus) very different in appearance from the common ribbon-wood.

\section{*Viola filicaulis and V. Cunninghamii.}


It is a small branching shrub with small narrow leaves and solitary flowers, but these have the same structure and are very fragrant. The plant seems unable to grow away from salt water.

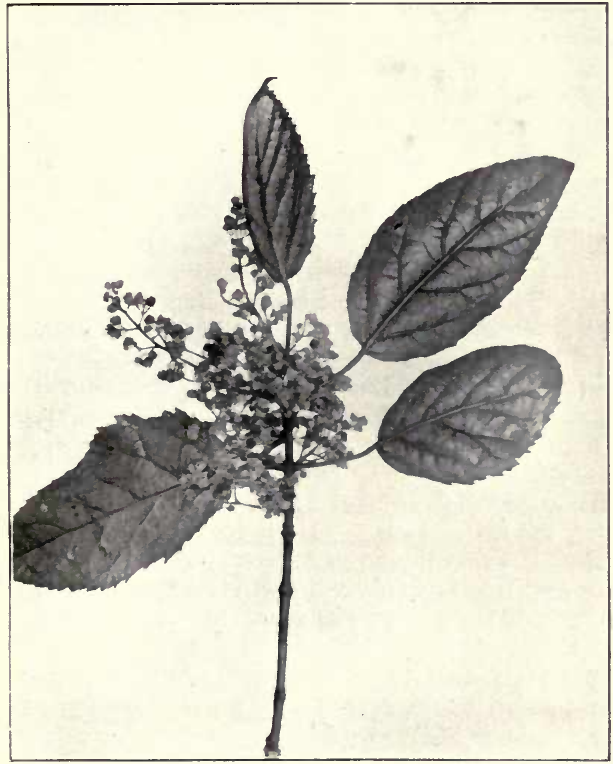

Mako-mako (Aristotelia racemosa).

Another common plant in our bush is the native currant or mako-mako (Aristotelia racemosct). It is usually quite or nearly deciduous in this part of New Zealand, though evergreen in the North Island at all low levels. The species is interesting from the perfect gradation which it exhibits in its flowers between those which 
are completely hermaphrodite and others which are dioecious. In the latter the male flowers have twelve stamens in four groups of three each, and have no trace of a pistil. The most complete female flowers have a four-celled ovary but no trace of stamens. Hermaphrodite flowers also occur with twelve stamens and a four-celled ovary, and between these extremes every gradation may be met with, sometimes even on the same plant. The flowers are produced in great numbers, the male particularly, so that the bushes are bright red with them. They have no perceptible fragrance and no nectar, and the pollen is of so light and dusty a nature that $I$ think they are tending to be windfertilised, though no doubt insects have a share in this work. I have often shaken snall beetles out of the flower. clusters, and as these are mainly pollen-feeders they no doubt help in the work of inter-pollination.

There is another species of Aristotelia (A. fruticosa) common in gullies and sheltered ground in the upper and inland parts of Otago, and found on the slopes of Swampy Hill, above the Leith Valley. This is one of those variable forms of plants which appears to me to be undergoing modification into two or more distinct species. It has all its parts much reduced as compared with the other species, and the extreme forms are very different from one another-one forming an erect bush, and the other being a low-growing tortuonsly-branched small-leaved plant with its clusters of blossoms sometimes reduced to single flowers.

The Maoris used to eat the berries of mako-mako in olden times. Another curious and notable thing about these plants is that whenever a piece of bush land is cleared of big trees Aristotelia is among the first to appear and form a grove of small trees.

All three kinds of tutu* usually commence to flower in October. Everyone in New Zealand knows, or ought to know, the common tutu (Coriaria ruscifolia), but the smaller species grow in higher country, and about Dunedin one must go up to the slopes of Swampy Hill, to a height 
of 1500 feet or more, to see them. The Howers are not particularly attractive to look upon, yet to the botanist they are most interesting. They are hermaphrodite in structure-that is, they contain both stamens and pistil, yet they are as incapable of self-fertilisation as if they had been dicecious, which they are in function. This is brought about by a curious device known to botanists as protogyny, one which is not uncommon in plants which are fertilised by the wind. As soon as the little green flowers open the red stigmas expand and project to a very considerable extent. After two or three days' exposure they wither away, and then the stamens are thrust forth, and their pendent anthers scatter ont little clouds of dusty pollen. Nature seems very prodigal in the enormous numbers of germs which are cast forth in the perpetuation of species; but perhaps a more wonderful thing even than the vastness of the numbers which are produced only to die is the immense potentiality which exists in each one of these microscopic germs. The common tutu is always hermaphrodite; the smaller alpine forms are sometimes dicecious.

A few heaths come into flower this month. The commonest and best known of these is the snowberry (Gaultheria antipoda), one of those extremely variable forms which ought probably to be divided into several distinct species, ranging as it does from small creeping shrubs to small trees of erect habit and 20 feet or more in height. It is the only plant of the order known to me which shows a tendency to separation of the sexes in the flowers. In some plants truly hermaphrodite flowers are found, but in these the stamens matme considerably before the stigmas. In others the stamens are in a more or less aborted form until a stage is reached where the anthers are represented by small bent portions on the summit of a diminished filament. The base of the corolla always contains nectar. The stamens are very curious in structure, as is the case in so many heaths; the anthers have as a rule two little horns or awns at the back, and they open to let the pollen 
out by a small pore or hole at the top. The same mode of opening is better seen in the rhododendron, in which the flowers are so much larger.

Another very common heath, which grows abundantly in dry grassy ground on the Town Belt and elsewhere, and which is perhaps best known by its small orange-coloured and orange-smelling fruit, rejoices in the name of Leucopogon Frazeri. The name of the genus is derived from two Greek words meaning “white beard," and its appropriateness is seen by looking into the tube of the corolla and observing how it is nearly quite closed up by hairs. The object is clearly to keep out small insects and all those which are unable to fertilise the flowers. This work is done by moths which have a long and slender trunk. They are attracted to the flowers by their powerful fragrance and by the large drop of nectar at the base of the corolla tube. Their trunk passes easily through the hairs, and in pushing their heads forward they no doubt convey the pollen which they get on the front part from flower to flower.

Besides the plants mentioned, many others are now to be found in blossom. The common white-flowered flax (Linum monogynum) occurs on rocky and sandy ground along the whole sea coast. On Tomahawk Head and similar spots a minute stemless buttercup (Ranunculus acaulis) may be seen thrusting its little golden flowers an inch or so above the sand. Several Olearias, Celmisias, and other composites begin to display their blossoms, as do the little white and blue bells (Wahlenbergia gracilis). Those who are near the bush should now look out for the little clusters of flowers on the pine trees. There are seven different kinds of conifers (so-called) in the neighbourhood of Dumedin, and very few people even seem to know that they flower just as regularly as other trees. They are the cedar (Libocedmus biduilli), red and yellow pines (Dacrydium cupressinum and D. colensoi), and four species of Podocarpus, viz., miro ( $P$. fermugineus), black pine or matai ( $P$. spicatus), white pine ( $P$. dacrydioides), and totara ( $P$. totara). The cedar has small cones, but 
all the others produce one or more naked seeds placed on a swollen peduncle, from which the name of the genus is indeed derived. The miro berry is only the end of a branch swollen up to resemble a succulent fruit, and serving the same purpose-namely, to attract birds to the plants so that they may eat and thus disseminate the seeds.

Before leaving the subject of flowering plants, it may be noted that the large Astelias - those handsome flag-leaved plants like New Zealand Flax-which grow so commonly

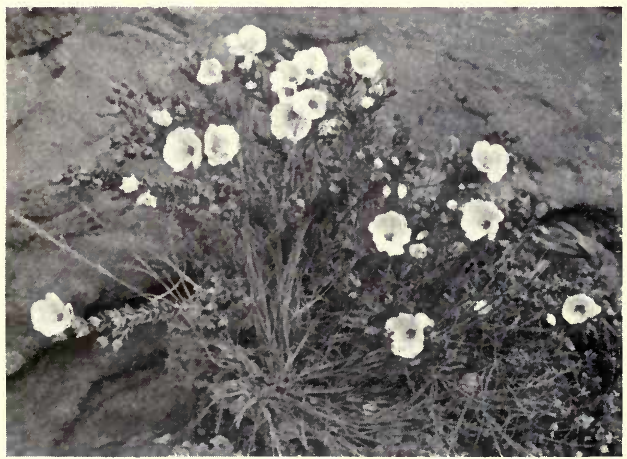

Linum monogynum.

on the edge of the bush and which flower about this time of year, exhibit the same peculiarity of structure which has been already referred to. The flowers are hermaphrodite in structure but are quite dioecious in function. The nale flowers have small and imperfect pistils, but these never ripen to berries. The female flowers, also, have stamens, but they are apparently always destitute of pollen. Probably the same thing occurs in the common pink-flowered Mesembryanthemum or fig-marigold, which grows so commonly on rocks near the sea. Hooker says 
it is unisexual, but I have always found it to be complete in all its parts. It may be, however, that the organs are not fully and equally developed in the different flowers. Then there is no doubt also that the same species may be hermaphrodite in one part of the country and in anotherperhaps a warmer portion - it becomes distinctly unisexual. This is certainly the case in the white mapau (Pittosporum eugenioides), which is always hermaphrodite in and about Dunedin but is diœcious in most parts of the North Island.

As all forms of vegetable life tend to grow with increased vigour as the weather gets warmer, it will be found that now is the time to note and, if possible, combat those parasitic fungi which so often attack cultivated plants. For some year's past a mildew has made its appearance on the thorn hedges, and nearly always its attacks are noticeable early in October. The chief objection to it is the unsightly effect it has on the plants if it is strongly produced. It only shows itself on the young shoots, and when these are pruned off they should always be burned. When such parasites attack roses and fruit trees-which being semi-artificial productions are much more liable to suffer from fungoid diseases than plants grown direct from seedthey seriously diminish the vitality of the plants and thus impair the production of flowers and fruits. One of the most effective modes of destroying or at least impairing the vigour of these pests is to spray the plants with a weak solution of calcium sulphide (nade by boiling lime and sulphur together in a kerosene tin and diluting the solution with a considerable quantity of water). A very thin film of ealcium sulphide is thus left on the surface of the leaves and this decomposes on exposmre to the air and leaves a skin of calcium carbonate and sulphur. It is the latter substance which seems to be so obnoxious to the fungi.

In some gardens a curious fungus, a species of Puccinia, attacks the leaves of anemones and prevents the plants flowering. The leaves become thick and yellowish and are covered, especially on the lower side, with dark spots. 
These eventually burst out like miniature craters, having an orange-yellow cup with fringed margins, and they scatter forth quantities of spores. Similar rust fungi attack the buttercup and the common groundsel, while another form produces great thickenings on the flowering panicles of the Clematis. 


\section{Chapter XIII.-Moeraki.}

A FTER a year's close application to work there is nothing so restful to mind and body as to get right away from the scenes and associations of everyday life and indulge in a little idleness. It was said of the late Lord Randolph Churchill that after the stress and excitement of his parliamentary work he used to run down to Brighton to a favourite quiet hotel and keep his bed from Saturday to Monday, returning to the arena refreshed and invigorated. Chacun à son gout. Most of us under the same circumstances would prefer to go to some quiet seaside resort, where, unbending from the conventional stiffness of our daily life, we can abandon ourselves to the pleasures of doing nothing. Our coast line abounds in charming nooks and retreats, the only drawback being that in many of them we have to dispense with a good deal of comfort, and have to rough it more than is compatible with thorough rest. But there are numerous exceptions, spots where one ean have plenty of the material comforts which help so largely to make up much of the pleasure of daily life, and at the same time indulge in the negligent freedom which is part of the charm of a thorough holiday.

Moeraki is one of those favoured spots. I believe its Maori name means "sleep all day" or something analogous to that, and its air on a fine summer's day suggests the appropriateness of the term. It has the reputation of being too often dry and dusty, cut off as it is by the Horse Ranges from most of the prevailing westerly rain-bearing winds; but this damp summer has just suited it and given the place an ideal aspect. The eye never wearies of green grass, setting off as it does the more sombre hues of the bush, and on a calm afternoon when

\section{"All the sky}

Is flecked with soft white fleecy clouds which cast Bewildering charms of shadow, and beyond" 
the placid summer sea lies in alternate bands of emerald and purple, the mind can drink in the beanties of Nature without feeling wearied or satiated.

Wherever comparatively recent volcanic action has left its mark Nature has toned down her roughnesses and hidden her angry work under softened outlines. Moeraki lies in a bay formed by a mass of eruptive rock which has been thrown out seawards in comparatively recent times. If we surmount the rounded hills which lie behind the point we find hard straight walls and dykes of lava running out to sea, thus breaking up the coast line into an ever-varying succession of headlands and reefs alternating with sandy bays. Between and over these dykes of hard trap rock lie masses of tufas and volcanic debris, which have crumbled under the influence of the ages into a rich brown soil, in which, wherever there is sufficient moisture, everything grows luxuriantly. Some, however, of these beds of volcanic ash have broken down into a peculiarly tenacious clay, and by the lodgment of water in the hollows of the high ground this has oozed down every here and there, causing extensive landslips, so that the whole face of the hillside towards the bay is broken by these slides. Wherever this clay is exposed and dried it becomes very hard, but in wet weather it is a revelation to all newcomers, who perhaps incautiously step on it once when going down to the beach, but who usually take care not to repeat the experiment. Probably the clay contains a certain admixture of hydrated magnesium silicate, a substance which connunicates a slippery or soapy consistence to minerals in which it is present.

A change has come over the regetation of Moeraki since I saw it first, which was early in the seventies. Introduced plants have nearly quite crowded out all the smaller indigenous plant life. The common Hedge Mustard,* a rather harsh-looking crucifer, has taken possession of very considerable areas, and grows most luxuriantly, throwing up long nearly straight stems against which its stiff 
rounded pods are closely pressed. It is not an attractive plant as a rule, except under most favourable conditions, and as at Moeraki it seems to be very commonly attacked by a fungus which distorts and blackens its stems and leaves, it is apt to become rather an eyesore than otherwise. It is quite common to find it growing to a height of four feet or more, especially in the bush, where it forms troublesome tangles and thickets. The Barley Grass,* a coarse prickly species, with a partiality for the seaside, is another abundant invader, often to the exclusion of more desirable grasses. Three thistles, including the handsome Cardums marianus, which has probably escaped from the garden of some enthusiastic North Briton, and the small pink-flowered C. pycnocephalus, are common. One or two other introduced plants which are not yet spread over other parts of Otago here find a congenial home, such as the Hedge Parsley (Caucalis nodosa), which I have not net with in this colony before, and one of the wild cresses (Lepidium muderale). It was curious to find that the ground between the grassy patches near the sea was at the time of $11 y$ visit in late Summer everywhere covered with small black spiny pods, suggestive of curled-up caterpillars. These proved to be the seed vessels of the Spotted Medick, $\uparrow$ a species of yellow-flowered clover, which must have covered the ground in Spring-time, and after flowering and fruiting has almost died out for the season, being largely replaced by grasses. Besides this, the common yellow clover (Trifolium procumbens) was abundant and luxuriant. In the remains of bush now found in the reserve it was interesting to notice that wild gooseberries were spreading so thickly as in places to form quite a dense undergrowth. These have originally escaped from gardens, and have been spread by the birds, just as is being done with the elderberry in the Town Belt of Dunedin. I cannot say whether it was due to the specially damp season or not, but the fruit was in many cases as large and fine as one gets in a garden, and there seemed to be a large quantity of it. I

* Hordeum murnum. + Medicago maculata. 
noticed a patch of the Cape Gooseberry, or Tipari,* as it is called in India, growing wild in the bush. This would be an interesting acquisition if it would increase and grow as it does further north in this colony, for its fruit makes most beautiful and excellent jam. But it is here near its southern linit of growth, and only ripens its berries in war'm seasons. The Ngaiot (usually mispronounced Kaio in the southern part of the colony) is the tree which seems to thrive best along the coast. Many fine specimens occur near the roadsides, and it might be more extensively planted with advantage to the landscape and for the sake of its usefulness. Its wood, though not produced of a large size, appears to be of excellent quality, and we were interested to see that it was being made use of in the building of a large boat intended for the local fishing trade. Besides ngaio, the pretty Hoheria was found in fine flower in the Maori reserve. This is a tree which should be found in every suburban garden; both flowers and foliage are beantiful, and it has a very graceful habit. The common hedge plant at Moeraki is the African Box-Thorn, which makes a pretty shrub when its branches are covered with their fine coral-red berries.

A seaside place would be of little interest if one could not go at low water and poke among the rock pools. The reefs on the ocean face of Moeraki Headland form an excellent hunting ground for the naturalist, as they run out for a considerable distance, exposing at low water long flat shelves of seaweed-covered rocks full of large and small pools. Such places are a never-failing source of interest. After a storm, when the waves have torn off great masses of tangled weed and sea-wrack and hurled them up with all their living freight on to the sandy beaches above the reefs, the collector can get a harvest of material. But if he comes on the beach some days after a gale he will find how rapidly a heap of seaweed is attacked and removed once it is out of the reach of the waves. If a frond be seized and dragged away so as to open up a heap, myriads

* Physalis Peruvzana. + Myoporum latum. 


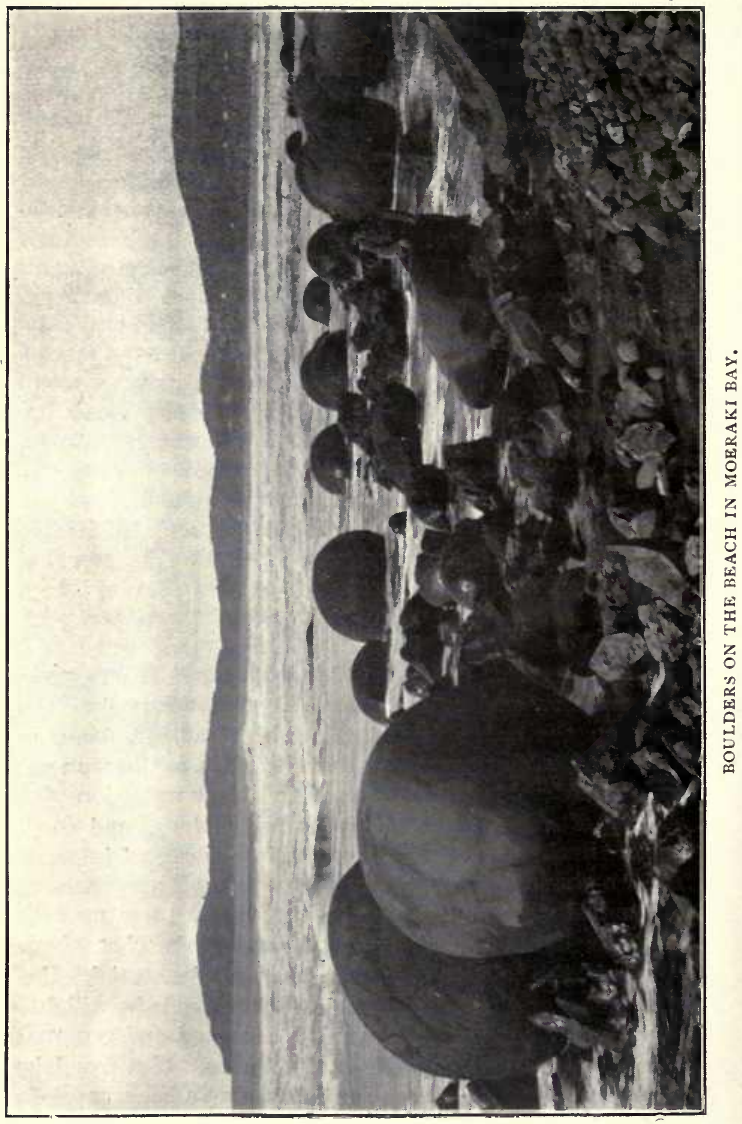


of flies are exposed all busy feeding on the decaying weed. The number of these flies is marvellons; they seem to form living masses in suitable localities. If we drag away the weed till the sand is bare we meet with crowds of shore-hoppers, which skip away briskly or burrow rapidly into the sand. Among these may be found large black earwigs, some of the curious staphylinid beetles with their short wing-cases which only cover half their bodies, and also small black ants. The flies and the hoppers mainly feed on the weed, though the latter are as thorough going cannibals as can be met with, while the earwigs and the ants are carnivorous and help themselves to the other scavengers.

But the pools are the chief somce of attraction. They are seen at their best after a few days of quiet weather, when the various animals which live in the shallow coastal zones of the sea are tempted to come shorewards without the risk of being pounded to death by the unceasing pitiless surge. Shrimps and prawns of several kinds, hermit-crabs, sea-slugs, and other curious denizens of the deep, creep up at high-water on to the weed which covers the reefs, and as the tide recedes they are left, along with various species of shore fishes, in the pools. It is interesting to notice how much protective colouring comes into play among these creatures. The fishes of the rock pools are nsually blackish or dark gray with whitish stripes or markings, so that when they lie still in the weed-fringed clefts of the rocks they may be looked straight at without being seen. It is only when they move that their presence is revealed, and then with a dart they dash through the limpid water for a foot or two and again become invisible. The shrimps and worms which are exposed are frequently of a greenish hue so as to harmonise with the prevalent weed. There is a common red shrimp also found on these reefs-a peculiar little species* which progresses by active leaps when disturbed, but this always takes care to hide under stones. Similarly, the reddish worms, which are always snapped up quickly by fishes when exposed, dwell mostly in tubes, and only put their

\section{* Betceus aequimanus.}


heads out to see what is going on in the outside world. The sea-slugs are usually very brightly coloured, and are really most elegant creatures when seen in the pools, with their pearly white or clear lemon-yellow bodies and their beautifully plumose gills. They are so conspicuous that we must suppose that they are not very good eating, otherwise they would be quickly decimated. Sea-anenones of many hues and sizes often line the cracks between the rocks in the pools, opening out their wide tentacles like the petals of a cactus. If we drop a worm or a bit of meat into the centre of the flower the arms close rapidly and engulf the morsel.

One reason why pools on a rock-bound coast are so interesting is no doubt the constant element of change which they manifest. Not only are the objects very numerous, and often very peculiar, but there are constantly new forms appearing, and the variety is infinite. It is this unceasing changefulness of aspect which makes the sea itself so interesting, and which keeps one from wearying when contemplating its protean moods.

No reference to Moeraki would be complete which omitted to notice its boulders. These singular spherical masses of rock really lie on the beach half way to Hampden. They are not so numerous now as they were a score of years ago, the smaller ones having been constantly carried away as curiosities or mementos. Some of them may be seen fractured by the action of the sea. They are found to contain cavities lined with crystals of calcite or calcium carbonate. Geologically these singular stones are known as septaria, and they are concretionary structures derived from the blue sandy clay which here forms the predominant rock. The formation is a sedimentary one, and is, of course, quite different from the volcanic rock of which the headland is formed. As their scientific interest is great, it is fortunate that there are still many of these boulders left, and of such size that no collector, however enthusiastic he may be, or however destructive his propensities, can succeed in doing away with them. 


\section{Chapter XIV.}

\section{Rambles round Dunedin.*}

' THE study of geography should begin at our own doors, 1 and the immediate surroundings of om home and neighbourhood can furnish abundant material for a whole course of lessons on every branch of natural science.

This proposition was frequently strongly emphasized by Huxley, and his book, entitled Physiography; an Introduction to the Study of Nature, published in 1877, was an attempt to realise the idea, and lead other's to what he considered the right lines of study in this direction. starting from London as a centre, he sought to lead his readers to consider the varions agencies which had been at work during the preceding ages to produce the present contour and surface features of the Thames valley. The work, though professedly only an introduction, was of in extremely suggestive character, and it led me some years ago to apply the ideas - in part-- to the surroundings of our own romantically situated town. It seemed to me that an attempt to sketch out the main features of the watershed in which Dunedin stands would interest me and other's also, and all the more, perhaps, that the areathough of a very diversified nature - was a limited one. My notes on the subject were used as the basis of a course of lessons in Physiography, and I thought it would be an appropriate and interesting subject to bring under the notice of the members of this Institute. The whole ground included in the survey is readily accessible, and all of it abounds with most charming walks and views.

A good walker--that is, a man who can do thirty miles in a day without feeling any the worse of it - can walk round the crest of this watershed in a day. He will, of course,

* Delivered as a Presidential Address to the Members of the Otago Institute. 
exclude from his pedestrian journey the whole of the Peninsula and the North-east Harbour. Let us follow his course-it is not one for a bicycle, which is a very excellent machine for merely getting over the ground, but does not conduce to the cultivation of the observational faculties, as its rider is chiefly concerned with the inequalities and grade of the surface on which he travels.

Starting from the cliffs above St Clair, and always keeping to the very crest of the ridge, he follows down the coast in a due westerly direction for about two miles and a-half, and then turns N.-N.-E., so as to circumvent the heads of all the gullies which run into Caversham at Corstorphine. This will bring him to look-out Point, from whence he will walk along the road behind the Industrial school, along the back of Mornington and the main High Street of Roslyn, nearly to the top of Iriver's Road in Maori Hill. Part of the way the road does not quite follow the ridge, but it is very near its crest, and the general direction is N.-F. Now he turns in a westerly direction across the end of the Golf Links, past Balmacewen, out to the Half-way Bush. After walking on for about a mile and a-half he turns again nearly dne north, and follows the leading ridge till he reaches the summit of Flagstaff Hill, an elevation of 2192 feet. Nearly all this way, since leaving the coast, the watershed of the Kaikorai Stream has beell on his left hand. On the right he has had only the drainage basins of the numerous little streams which formerly meandered across the flats now occupied by South Dunedin and the south end of the town, but which now, confined in subterranean brick channels, constitute large and sometimes dangerous sewers. Walking along these suburban ridge-roads we have many a glorious view of wide-stretching landscape, but we find it difficult to realise that only half-a-century ago the first settler's looked down from the flax- and tussock-covered heights into ravines such as that now forming Maclaggan Street, down which ran clear and abundant rivulets, and whose banks were shaded with beautiful thickets of small trees and shrubs. After reaching Maori Hill, and until his 
ramble terminates, our pedestrian has the watershed of the Leith on his right.

Flon the summit of Flagstaff Hill the course continues in a nearly due northerly direction, going down hill, to cross at a height of about 18.50 feet a wide saddle which dips into Nichol's and Morrison's Creeks on the right, and to a feeder of the Silverstream on the left, and then it rises up the long slopes of Swampy Hill, and keeps along the summit, among its lagoons and peat mosses, at a height of some 2195 feet, for about two miles. All the high ground to the left since rising up the slopes of Flagstaff Hill drains into the Silverstream, a small part of the wide watershed of the Taieri River. Now the traveller. turns nearly due east, and comes down hill once more to (ross the saddle between the Leith and the Waitati, then up-hill to the summit of Mount Cargill, which stands 2232 feet above sea-level. From here, if he wished to encompass the whole watershed of the bay, that is, of Otago Harbour, his course would be across the North Road at about the eighth milestone, along the high ground to the summit of Mihiwaha, and out by the crown of the ridge to near the North Heads. But taking the shorter route, he would make a rapid descent to the North Road just about the junction of the old road to Port Chalmers, would keep along the crest of Signal Hill, and descend to the harbour side at Black Jack's Point. I have walked the whole of this course, with the exception of the portion between the crest of Swampy Hill and the summit of Momnt Cargill, and even part of that was formerly traversed by me on several occasions.

This is a bare ontline of the route to be traversed by anyone seeking to walk round the watershed of the Dunedin district, and it seems just a record of heights and howes, ridges and ravines. So incleed it would chiefly be to the man who did it all at one streteh, mless he had his eyes very wide open, and took a long summer's day to it. Even then he would not have mnch time to study what was under his feet, though he could hardly fail to enjoy the contimul change of scene which would greet his eyes as he 
moved from height to height. There is no walking so refreshing to mind and body as is met with on the crest of a ridge, where the view is not continually shut in, and as long as the wind is not too much in evidence. But to appreciate some of the salient features of the route trarersed-the geological formations crossed, the changes which have left the contours as we now see them, the vegetable life which has helped to make the surface what it is-we must go over the ground more slowly.

Let us mount the hill at St Clair and, before again setting out along the high ground, sit down on the greensward, and, with our outlook towards the mid-rlay sun, survey the landscape before ns. Surely it is one of the fairest that we can look upon in this fair land. Away to our right lies the illimitable stretch of the well-named Pacific Ocean, its waves lapping the foot of the basaltic cliffs which form the Forbury Head, now still and blue reflecting the deep vault of the heavens, now dark and sombre as the clouds throw their heary shadows over it, and then again green and white-topped as the fresh breeze tosses its waters in the bright and uncertain glory of a summer's day. There is monotony in the roll and ripple of the sea, but it is an unwearied and unwearying monotony, always the same in its rising and falling and yet protean in its unceasing movement. In front of us stretches "the long low dune and lazy plunging sea," the line of beach and sandhills reaching to Lawyer's Head and the foot of the Peninsula Hills, whose bold sea front is formed of cliffs nearly similar to those under our feet. These sandhills mark the rise of the coast line as they have been slowly gained from the sea by the blowing inland of the sand from off the reaches exposed at low water. Again and again have the waves tried to win them back, the wild waters beating at their base and sweeping masses of them under their dominion, but all in vain; the coast is slowly rising, and we see repeating itself here, as elsewhere in all this neighbourhood, the gradual building up of a sand barrier which some day may harden into a rock as it is already doing on the Lawyer's Head. 
But the mind dwelling on the past history of this stretch of dunes goes back in imagination to the time when the peninsula was an island separated from the mainland by a somewhat deep channel. We cannot say how long ago this was, but the fact is incontrovertible. The Flat, as we now call it, is only a little above high-water mark, and no loubt some of us can recall the time when it was a succession of lagoons and morasses which in time of heavy rain and high tides used to form a continuous sheet of water. I remember that shortly after houses began to spring up in South Dunedin there came such a conjunction of wind and weather that the inhabitants had to be got away from their dwellings in boats.

When the first settlers came to Dunedin they found a tract of low-lying alluvial land covered with bush in many parts forming the Harbour shores north of Bell Hill. Standing on this rocky eminence, near where the First Church now stands, and looking north to another hill of which a portion still remains between North Dunedin and Pelichet Bay, they saw a marshy tract of land, passage through which was very difficult. First a large stream with deeply cut bed came down from Roslyn, passing near the site of the present Boys' High School, down by the line of York Place and St Andrew Street. Then another passed down near Frederick Street, and besides a number of smaller channels and déep swamps there was finally the Leith itself. Looking south-east there were many fine streams, one down the line of Maclaggan Street emptying itself into the bay near the site of the Customs House, and up to this point boats came for some time after the settlement was founded. Indeed they used to be taken up at high-water to the back of what is now Wood's Hotel. Another large stream flowed down the Glen, and still another down the middle of Caversham. These and many others brought debris from the higher land, and deposited it at the lower levels till they filled up the shallow arm of the sea at the foot of the hills and thus gradually formed the flat portion of our town site. It is not many years ago since a line of borings 


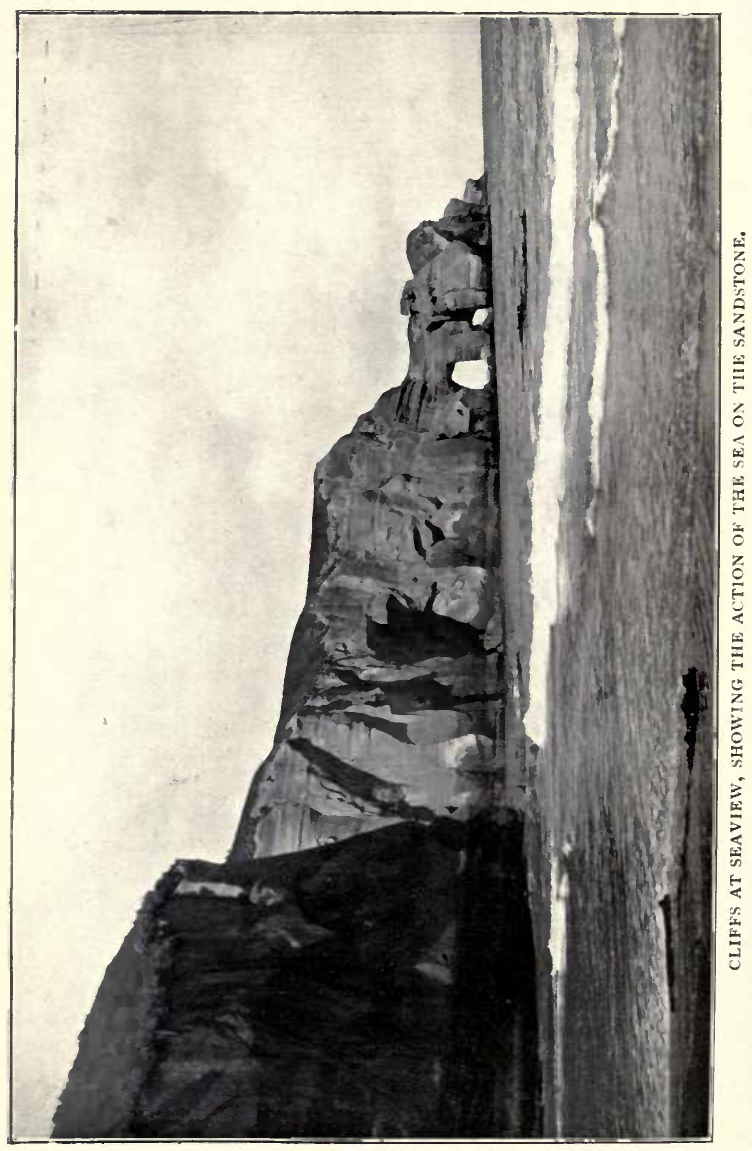


was taken across from the Anderson's Bay Road to the Ocean Beach, and this disclosed only beds of blue clay and shells runuing out on the ocean side into fairly deep quick-sands full of salt water.

But the insulation of the Peninsula was not within historic times. It has been affirmed that Captain Cook either brought his ship the "Endeavour" through this channel to where Dunedin now stands, or that he sent a boat in. But neither Cook nor Banks make any mention of the fact. Here is a passage from the diary of $\mathrm{Mr}$ Sydney Parkinson, one of the draughtsmen on board the "Endeavour." He says :-- "Having beat to windward for several days without gaining any way, with the weather gloomy and very cold, on the 24th (February 1770) we had a fresh breeze from the $\mathbf{N}$. which carried us round the outermost point of land we had seen, which we called Cape Saunders, beyond which the land tended away to the S. W. On the 4 th March, after having beat about near a week, we got sight of land again, and saw the appearance of a harbour, which we named Molineux's Harbour, after the name of the master of our ship." This is pretty conclusive evidence that Cook never came here, and I question if there was a channel deep enough for a boat to pass through 130 years ago. On this point, however, it is almost idle to speculate, for there are no data to go upon, as is often the case in old-settled countries.

From our point of vantage on the Forbury Head, looking up the coast - that is, in a due-easterly direction - a curious feature of the Peninsula presents itself. The basaltic rocks lie in parallel waves or sheets across the Peninsula, some three or four such great masses being visible from where we sit. These slope somewhat gently to the west, but drop sharply - in many cases almost precipitously - on their rastern face. The first and least perfect of these sheets or dykes ends its abrupt seaward face at Lawyer's Head; the third is the steepest and most pronounced; the fourth runs out to the sea near Sandymount. This last projecting promontory cuts off the further view of the coast.

The cliffs at St Clair are formed of basalt, showing 
columnar structure on the sea-face, while the superficial portions are often highly vesicular. A very short distance down the coast and we find the basalt rumning out, and can see that it overlies the massive strata of nearly levelbedded sandstone. This latter is a marine formation, containing shells, and takes us back to a period antecedent to that in which volcanic action became so pronounced in this neighbourhood. Our course along the water-parting takes us over this bed of sandstone till we approach Mornington, when again we pass on to the basalt. There is one considerable area of clay here, at a height of about 450 feet above the sea, which Captain Hutton considers to be of pleistocene age. As this rests on the top of the volcanic rocks it implies a very great subsidence in recent geological times, and although other beds of apparently similar age occur in other parts of Otago, along the east coast, it is rather remarkable that this isolated patch should be the only one occurring in this immediate neighbourhood.

The narrow crest of the ridge between Mornington and Roslyn rises in the latter suburb to a height of over 700 feet, and then dips steadily to the brow of Maori Hill, where it ends abruptly in basaltic cliffs some 200 feet or so above sea-level. But the underlying rock is not of uniform material throughout. A little to the north of the line of Ross Street in Roslyn there is a change in the formation. To the south-west of this line the superficial beds appear to consist of lava flows of very vesicular basalt with what I take to be beds of volcanic ash, all so porous that water cannot be got by sinking wells, and which weathers to a warm, friable, dark red (ferruginous) soil. To the northeast of this line of demarcation there is a colder more hungry soil with a retentive clay subsoil in which springs occur, and which before the days of close settlement yielded wells of good water. This soil is improved by liberal applications of lime, and is altogether less satisfactory to cultivate than the other. The transition from the one to the other soil is again readily seen on the road between Balmacewen and Halfway Bush, where one passes from the cold clay to a bed of volcanic ash or weathered 
basalt, characterised by its deep reddish-brown tint and more profuse surface vegetation.

Before leaving this ridge to turn away to the ascent of Flagstaff Hill, it is worth noting that the contour of the country forming the background of Dumedin is probably due to two chief agencies: first, the lateral flows of lava, perhaps alternating here and there with beds of ash; and second, the denuding action of water. The streams of water flowing down to the harbour have cut down to the rocks along the lines of least resistance, flowing in between the sheets of lava in many cases, and in others across them, according to the hardness and compactness of the rocks met with. As already pointed ont, this denuding action has washed down the softer parts of the hills into the harbour and formed the present flat. But as the area of the town became settled and the surface was broken by roads, cuttings, and excavations for houses, the rate of denudation would increase. The amount of material carried down into the bay by surface water is much greater to-day than it was fifty years ago. We have only to stand on Roslyn ridge on any day following heavy rain and look at the colour of the water flowing out along the foreshore to realise that one deluge of rain will sweep more mud into the harbour than the dredge can take out in a year. One is tempted when standing here and looking down to the harbour to moralise on the rapid filling up which is going on; but the harbour will ontlive our time, and I must resist the temptation and carry you off to other ground.

Walking from Maori Hill to Halfway Bush, and from thence by the summit of Flagstaff Hill to the crest of Swampy Hill, we have on our right hand the various tributary streams which flow into the Leith. The first of these is known as Wakari, or School Creek, so called because it rises behind the old school at Halfway Bush, now known as the Church of the Good Shepherd. This little stream flows into Ross's Creek a short distance below the Reservoir. Its course used to be very beautiful, and its thickly-wooded banks were favourable exploring grounds 
for many interesting plants, some of which, e.g., Melicytus lanceolatus, and its still rarer relative $M$. macrophyllus (the sarge-leaved hina-hina), have completely disappeared of late years. The ground behind Balmacewen, some of it now belonging to the Golf Club, was formerly in the hands of a butcher, and through this fine bush cattle used to roam and destroy the undergrowth. The finishing touch was the establishment of a fell-mongery or wool-scouring place near the head water's of the stream, by which the whole course of what was once a charming bush rivulet has been poisoned and polluted. Would it not be worth the while of the citizens of Dunedin and its suburbs to buy back such rights, and so redeem this beanty spot to aesthetic uses? I think it would.

The little bush at the head waters of the stream behind the school has completely disappeared, and over a great part of the slopes from the Halfway Bush Road, half way to the top of Flagstaff Hill, the native vegetation has been totally supplanted by gorse and broom. The growth of these plants has been phenomenal, and in the spring of the year when in full bloom they are beautiful beyond description. There are many people who cannot see beanty in anything that is common, but to those who can appreciate a work of Nature at its intrinsic worth I can appeal as to the magnificence of a heavily-flowered branch of either gorse or broom. No orchid, lily, or iris can excel it. Yet, I fear, we do not appreciate these plants. The farmer. cannot utilise them successfully, and owing to their enormous abundance they form a perfect shelter for vast numbers of rabbits, which, in spite of the numerous dogs and guns employed against them, manage to hold their own very well. Leguminous plants commonly enrich the soil on which they grow by the peculiar root-tubercles which they possess, and which are the abode of and are produced by nitrogen-fixing bacteria. These tubercles may frequently be found on the young roots of broom and gorse, so that if the superficial vegetation of these hills could be returned to the soil the latter would be greatly improved in quality. Unfortunately both plants are always cleared 
from the ground by burning, and thus the very element by which they might enrich the soil is largely dissipated into the atmosphere. What a wealth of honey seems to be wasted in the flowers of these plants! You may "watch the laden bees amid the honey flower's" of the garden, but you will not find them much among these plants. The hive-bees do visit the broom flowers, which explode on their pushing into them, and throw a clond of pollen over the intruders; thus they are fertilised. But the gorse, with its magnificent trusses of golden bloom, making the verual air heavy with their fragrance, is seldom visited. As a matter of fact there is no nectar in either of these flowers, and they are only visited by insects for their pollen.

As we get near the top of the hill we pass on our right hand several deep hollows, open towards the south-east, which are the collest parts of the whole countryside; and here. just where it can easily be seen from many parts of the town and its suburbs, the snow lies longest in Winter. During this year (1901), the severest perhaps on record, the snow lay continuously for over five months. A heary fall as early as April 27th soon disappeared off the whole of the surrounding country except in these hollows, where it lay till July 4th and 5th, when another deep fall again buried all the uplands in a white sheet. Renewed from time to time, it gradually melted off the hills, until in the first week of October only five drifts were visible, and these daily decreased in size till the storm of October 5th-6th once nore whitened the surface and gave them a fresh coating. There were one or two patches still to be found on October 13th, but the warm wind of the following day dissipated the last of them.

All the ground on this side of Flagstaff Hill drains into Ross's Creek, the second of the tributary streams of the Leith. The whole of this watershed is about 1000 acres in extent; and when the necessity of obtaining a permanent water supply for Dunedin became apparent this stream was selected, and its waters were arrested by a solid dam. At that time nearly the whole area was covered with dense bush. Since I first came to Dunedin I 


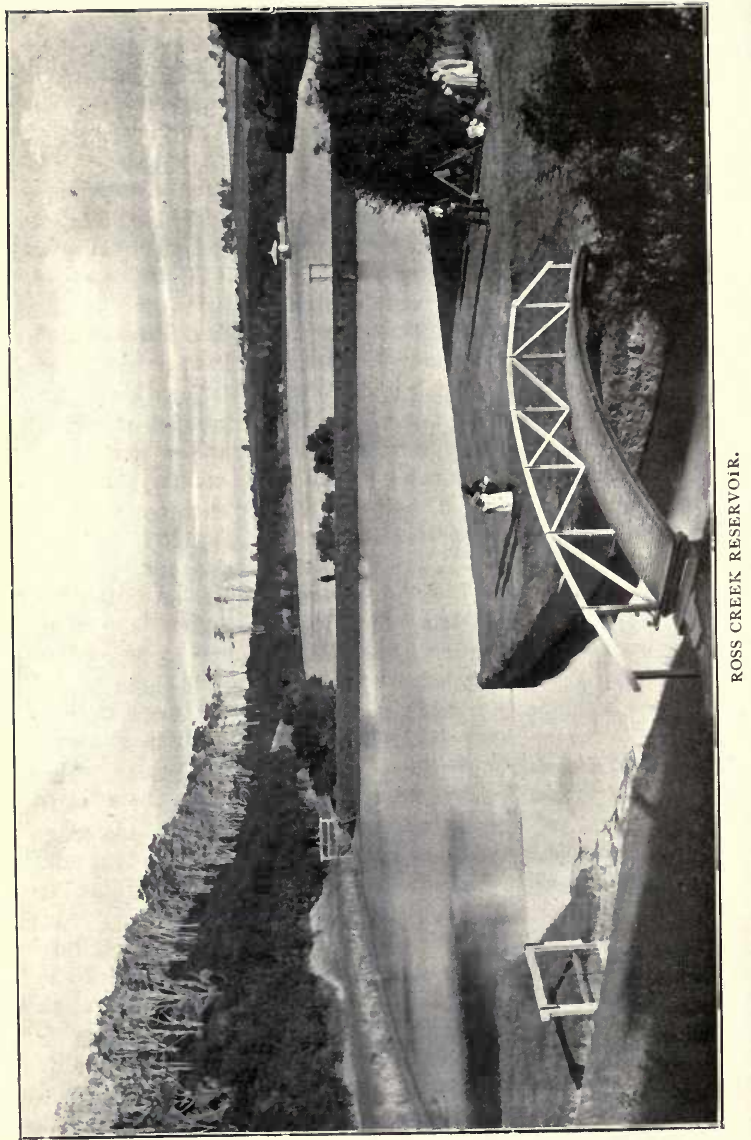


have never ceased to be amazed at the want of knowledge and of foresight displayed in connection with this reservoir -and this not by the municipal authorities alone but by the residents generally. Let me just state a few facts for your edification, for though we have come to find "books in the running brooks," we can hardly avoid finding a good many other things as well, and these things must be spoken about sooner or later. The reservoir when full holds some 51,000,000 gallons, and the water passes directly, without any attempt at filtration, into a 12-inch cast-iron pipe. This main pipe can deliver at the city boundary without any extra pressure about $4,000,000$ gallons in twenty-four hours. It is not, of course, run at this rate. Thus, as a case in point, I made inquiry in former years, and found that in August and September of 1884 about 4,000,000 gallons per week, or 570,000 gallons per twenty-four hours, were withdrawn from the reservoir. The working level of the water in the valve tower is 372 feet above the lowest point of Dunedin, so that the highest levels of the city are not reached by the water. Now, I do not wish to bore you with statistics, and yet a few figures are necessary if we would justify the statement that we have been lacking in foresight. If we take the average rainfall of Dunedin at 45 inches per annumand probably it is a good deal more on the slopes of Flagstaff Hill than our records of past years give for the town - then there fall into the watershed of Ross's Creek every year somewhere about 1,650,000,000 gallons of water. If we make a very liberal allowance for evaporation and overflows in heavy rains, and assume that only one third of the total fall passes into the reservoir, we should find nearly 550,000,000 gallons as the annual supply, or over $10,000,000$ gallons per week. The anount actually supplied in 1884 was estimated at 202,000,000 gallons, or much less than half the estimated amount, and the supply has diminished during these last years very considerably. The water is simply not there to draw out. No steps appear to have been taken, as should have been done from the outset, to so secure the whole area of the watershed 


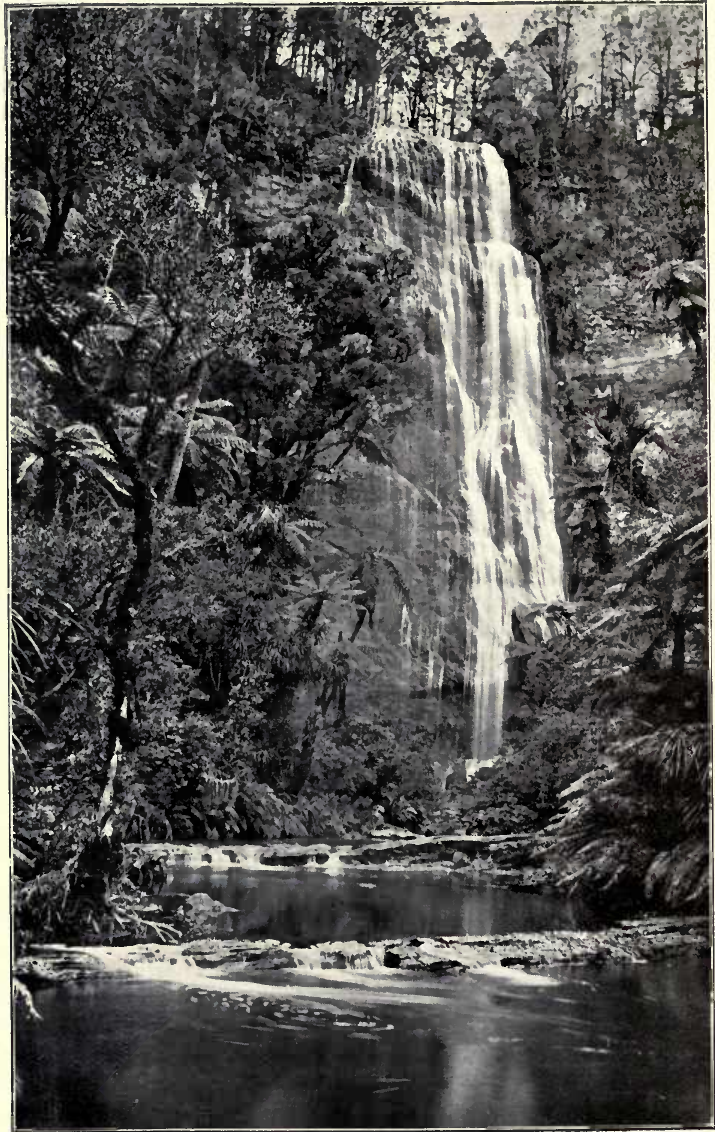

A TYPICAI, BUSH CREEK. 
that it could never be alienated from its main purpose, viz., that of catching water for the town supply. But year by year the bush disappears, the forest-clad areas are a steadily diminishing quantity, and the surface becoming bare. Water is not caught and held by the bush, and allowed to percolate slowly out of it, to anything like the extent which was formerly the case. Heavy rain falls on the hard dry surface and mushes off it, so that the value of the whole as a catchment area has been seriously impaired by the mere fact of clearing the surface. But this is only one bad feature of the case. Settlement has been allowed to take place all over it. Mr Ross's own house formerly stood on the banks of the stream at a considerable height above the reservoir, and although it was abandoned, other houses were allowed to spring up lower down and on other arms of the stream, and for years their drainage has either flowed directly or indirectly into the town water supply. The other day the corporation authorities took action against one of the residents for allowing the drainage of his pigsty to run into the stream, and the public awoke to the fact as if it were something new, when in reality it has been going on for a score of years.

Now the first cost of this water supply to the city was over $£ 140,000$, on which the ratepayers have paid interest ever since, and have got a property that is daily losing its value. But it would not be a difficult matter to arrest the destruction of this valuable asset. In my opinion it would pay the city well to buy out every owner in the whole area - the land is not in the Taieri Plain - and to plant it once more with the native bush and let it run wild. We should soon once more have a clean water supply and much more of it, and the community would be benefited in every way.

The next stream up the Leith is Nichol's Creek, which drains the north-eastern slopes of Flagstaff Hill and part of Swampy Hill. What is one to say of it? "A thing of beauty," says Keats, "is a joy for ever"; pity, then, that it cannot always remain a thing of beauty. When first I wandered up the bed of this streamlet it was a typical 
bush creek. The vegetation grew so thick and overarching that one could barely get a glimpse of the sky. Trees and shrubs, their stems and overhanging branches laden with epiphytes, crowded down to meet each other over the narrow bed of the streamlet. The walls of the gorge were loaded with the dark green dripping fronds of the Lomaria. The very stones in the rushing water were almost hidden by their dense mantle of mosses and liverworts, creepers and orchids, the quaint purple flowers of the latter relieved by the delicate green of the Oxalis-representative and counterpart here of the pretty Wood-sorrel of the old Homeland, and like it starred over with tender and fragile white blossoms in the later Spring. Then in Autumn the bright green Nerteras were covered with little scarlet berries, looking so charming in the fugitive glimpses of sunshine which penetrated these umbrageous retreats. It was inevitable that as people crowded up the stream to see the lowest of its five falls some of these things should disappear: but why did we allow the bush to be cleared and the abominations of barbed-wire fences cut us off from one of the finest beauty spots near town?

I hope you will excuse these digressions as being not without relevance and importance in such a desultory and vagrant paper as this is.

And now let us once more get back to the top of Flagstaff Hill and have a seat on the very summit before resuming our northward walk. We may with advantage descant on the beauty of the landscape which, turn where we will, spreads out before us in all directions. Away in front stretches the boundless ocean, its northern aspects cut off by Swampy Hill and Mount Cargill, but its coast-line far to the south only limited by the Nuggets some 60 miles off. Below us lies the Taieri Plain-" tracts of pasture sunny warm" mingled with fields of golden corn, the very Garden of New Zealand, into which so many of the early settlers looked and, dreading its deep swamps and lakes, and its streams "gleaming silvery in the shallows, glooming darkly in the pools," stopped short, and built their humble dwellings on the cold hillsides. How many have since lamented 
the lack of foreknowledge which caused them to halt on these Pisgah heights and forbade their advance into the deep rich soil of the plains. Away south-west, beyond the Waihola Hills, we see the high ground behind Waiwera. Maungatua stands up to a height of 3000 feet and bars our western view, but northwards of it rises the long line of the Lammerlaws and the Rock and Pillar Range, their 4000 feet wall barring further vision. To the north-west and north lie Mount Allan and the Silver Peaks, while the Kakanui Mountains bound the view almost to the sea again.

It is a wide prospect, stretching over a hundred miles, and very beautiful in many directions, especially down the harbour and over the Peninsula, but it just lacks what Ruskin considered the essential feature of a landscape, the historic association. Think of the view from the terrace of Windsor Castle, with its rich and lovely champagne country; or from Salisbury Crags over Edinburgh, how every inch of ground is alive with memories of the past; or that noble landscape from the brow of Kinnoul Hill, with the fair city of Perth and the beautiful sweep of the Tay at one's feet, across to the wooded slopes of Moncreiff Hill, up Strath Earn to the right and down the famous Carse of Gowrie to the left; or, again, the lovely view from the hill behind Heidelberg across the vine-clad valley of the Neckar and away down the Rhine. How the poet and the historian make these and other well-known spots live again in our imaginations! But here there " is no storied past"; the human element which gives such a charm to these old lands is wanting, and even nature is not seen at her best in this our age of transition.

The bareness of the surface to-day and the lack of animal life give little indication of the conditions which prevailed half a century ago, before guns and fires, cattle, sheep and rabbits, had so altered the state of affairs. Masses of flax and speargrass, intermingled with tussac, matagori scrub, snowberry, and anise, covered the open ground, and among these grew a great profusion of smaller heaths and nerteras, yielding abundant food for birds. In spring and early 
summer the open spaces were yellow with native buttercups and Maori onion, followed later by white Gnaphalium and violets, pink Epilobiums, yellow Senecios, and numerous small orchids. Still later, as the summer advanced, the blue orchids (Thelymitra) and the star-like Herpolirion brightened the gromd, to be followed by the white and red snowberries and the orange drupes of Lencopogon. Kakas were abundant in those days both in the bush and in the open, where they dug at the roots of the speargrass and flax for the large grubs and beetles to be found there, or visited the flax flowers for nectar and the snowberry and ground tutu for their fruit. Parakeets also fed freely on the berries, while tuis and korimakos visited the flowers for nectar and made the air vocal with their belllike notes. Wekas, grass-birds, and quails (now, alas! quite extinct) were abundant on the open ground or in the dense scrubby undergrowth; while native canaries, saddlebacks, wrens, warblers, robins, tomtits, and flycatchers, were as common as sparrows are to-day. In still earlier days Moas and perhaps Notornis roamed over these hillsides, for the former have left their mark in many parts of Swampy Hill in the heaps of gizzard stones which show the spots where they lay down to die. Lower down, in the bush-clad slopes, and in the denser vegetation of the ravines, kiwis, grom thrushes, and crows were abundant, and, no doubt kakapos also occurred; while in the upper foliage the silent wood-pigeons were very common, feeding in spring and early summer on the kowhai leaves and later in the season on the berries of mistletoe and the turpentiny fruits of the miros and other pine trees. The smaller birds, too, fed on the berries of the hina-hina, pepper trees, mako-mako, and poro-poro, and thus spread their seeds far and wide. Where are all these birds gone? Ask last year's snow. It was perhaps inevitable that they should disappear before the advent of man and his accompaniments; but the change has left us infinitely poorer.

Thus moralising on the past, let us again address ourselves to our northward path, and walking down the sunny slope cross the saddle at the head waters of Nichol's Creek and 
mount the ascent before us. Quickly the nature of the ground changes, becoming soft and yielding under foot. Swampy Hill is so named because its surface is in so many parts covered with a dense growth of Sphagnum moss, which has produced large beds of peat, in which are situated considerable lagoons and pools of brown bog water. These deep sphagnum beds, which hold water like a sponge, and into which one sinks halfway to the knees, are among the most interesting botanising grounds in the neighbourhood of Dunedin. Only the upper portions of the plants are alive. The tips of the branches are pale green, and they chiefly grow by a process of mere vegetative reproluction, new buds constantly giving rise to new branches, but spore capsules being difficult to find. At a depth of a few inches the stems appear white and blanched, and as we penetrate lower into the mass we find them turning yellowish, and then brown, till finally we pass into the blackish half-formed peat. Its mode of growth raises the whole level of the surface, and as water accumulates in the mass it often happens that the centre of a wide bed of sphagnum dies away or is drowned, while the outside continues to grow till a lagoon is formed. Such peat mosses, with their contained lagoons, are common in many parts of Otago, and are not infrequently found on the highest ground, as on the summit of Maungatua, of the Blue Mountains near Tapanui, and here on Swampy Hill. They must have been even more abundant in former epochs, for much of the brown coal or so-called Lignite of this part of New Zealand has been formed from peat.

The peat-forming plants are not all sphagnum, though this is the basis. We meet with species of Coprosma, Gaultheria, Nertera, and many sub-Alpine Sedges, while the beds are gay in midsummer with numerous small orchids (species of Caladenia, Chiloglottis, and Lyperanthus), Helophyllum, Forstera, and other pretty Alpines. Upon this high ground, which owing to its very wetness has not been swept by the fires which have destroyed so much of the vegetation all round, we are on an outlying spur of the mountain vegetation of Central Otago; and here we 
meet with a few examples of the Alpine flora of New Zealand. Here, and on the top of Maungatua (which, however, is nearly a thousand feet higher), are several plants of the Antarctic type, similar to those which are found on the granite peat-covered country about Port Pegasus, in Stewart Island. Down the slopes, too, of this hill occur beds of both forms of the Alpine tutu-Coriaria thymifolia, identical with the Andean form, and $C$. angustissima, the delicate-leaved ground tutu of Otago, together. with the mountain species of mako-mako (Aristotelia frutecosa). On a still hot summer's day the abundance of insect life on this hill is surprising, - moths rise from the vegetation in myriads as one walks over the damp cool and springy surface. Formerly the drier ground used to be alive with grasshoppers, but the starlings appear of recent years to have nearly exterminated these and some other insects. The hill to-day is a much more desolate and a less interesting spot than it must have been half a century ago, when both animal and vegetable life were more abundant. To-day - with the exception of a few patches of bush-it is the only outlier of the native vegetation within many miles of Dumedin which has not been utterly invaded and occupied by the introduced flora.

The top of Swampy Hill is not a pleasant spot to be on when a thick north-east mist comes over it, as it fiequently does. The ground is sufficiently level to be utterly puzzling without a compass, and the comparative uniformity of the vegetation and the uncertain character of the footing combine to make it most difficult to find one's way over in a fog. Yet it must be remembered that in the early days of this settlement this high and wide tract of open country was the only route by which cattle could be taken from north to south, as the whole coast line was densely bush-clad. I have heard old settlers and drovers describe their experiences when bringing large mobs down from Waikouaiti to the Taieri Plain and the open south country, and finding the whole hilltop covered with a dense bank of fog for several days. Truly we who live comfortably in our town houses can hardly realise the severe conditions which 
prevailed when the Otago pioneers undertook those arduous labours, whose results we now inherit.

To walk from Swampy Hill to Mount Cargill across the low saddle between the Leith and the Waitati necessitates even yet the only bit of bush scrambling on our route. As late as ten or fifteen years ago this bush was intact, and was the abode of those lovely and delicate ferns which are so characteristic of the unbroken forest land. But it is now being rapidly swept away-one wonders what for, for of all occupations that of destroying the native bush for the sake of the firewood, and leaving in its stead the bare hard clay-seamed hill-sides on which the very grass is apt to be replaced by sorrel and other weeds that a few poor cows can hardly get a living on except in the summer months, seems to me one of the poorest that a working man can take to. Just look across from Maori Hill to the slopes of Pine Hill and Mount Cargill in the months of December and Jamuary. It is not grass that we see. The ground is not so much green as greyish-white from the abundance of daisies, marguerites, and stitchworts (Stellaria graminea) which are then in flower.

The complete barrier of hills which encircles Dunedin seriously interferes with its expansion, just as the natural silting up of its harbour has affected its position as a port. There are only about two routes by which railway communication with the country north and south could be obtained - in both cases by selecting the lowest and narrowest cols or recks in the surrounding hills, and piercing them by tunnels. One of these has provided the western outlet at Caversham. The other, at the saddle of the Leith and Waitati, was not utilised as it should have been, but with that cursed political bias which dominates so many men and schemes in this new country, the line was taken by an almost impracticable roundabout road to make it pass Port Chalmers. The increased cost due to interest on construction and five miles of extra haulage must always make the Dunedin-Waitaki section of the northern railway an extravagant one. And the price the community has to pay for this political job-the selling 
of a principle for the sake of a few votes-is that it is saddled with an incubus for an indefinite time.

Mount Cargill appears to be geologically very different from Swampy Hill. Both the main peak and the lower one to the north-east of it show the naked basalt projecting into precipitous cliffis, and the same formation occurs on its slopes and on Pine Hill, and away to the eastward again on Mihiwaha. But Swampy Hill must have been submerged since the elevation of its main mass, for pretty high up on its western slopes are beds of lignite and other sedimentary deposits. Perhaps they have some connection with the clay bed at Mornington already referred to.

My first ascent of Mount Cargill was made through deep bush, thick with crape and filmy ferns. The little bog just under the cliffs at the summit was full of Alpines and slender-leaved Astelias. My last ascent, more than twenty years after, was through fields covered with a poor growth of Yorkshire fog and sorrel and roughly fenced with fallen trees; then up through broken muddy ground poached deep by wandering cattle, which evidently, from the number of their footprints, had to travel far for bare sustenance among scattered remnants of scorched and blasted skeletons of old trees; and, finally, through a patch of burnt scrub, from which we emerged black and grimy to meet the smoke of a bush fire on the western side of the mountain, and which was sweeping over its summit in thick and hot puffs. We might well say "Ichabod," for the glory had indeed departed.

From the top of Mount Cargill to Signal Hill, and so down to Black Jack's Point, we are once more on familiar ground, but after a long day's walk one is not inclined to pause and examine its features. I have generally found that while everything is fresh and full of interest at the commencement of a long walk, it takes something of very special character to arouse any interest at the close of it. Yet here is the same tale of disappearing vegetation and its replacement by cosmopolitan weeds - half-a-dozen species of natives, which I could formerly gather on this ridge, had now completely disappeared. 
I N D E X. 



\section{N D E X.}

Acæna . . $\quad 56,74,84$ Acclimatisation of Birds . 153 Acridotheres . . . $\mathbf{1 5 2}$ Adder's Tongue $\quad$ 27, 120 Alpine Flora . . . 49 Alsophila . . . . $5^{8}$ Anemone . . . 55 Angelica . . . . 120 Annual Plants . . . 175 Anthornis . . . 23 Anthus . . . . 4I Ants . . . II5, 193 Apples . . . . 12 Araucaria . . . . $9 \mathrm{I}$ Areca . . . . 172 Aristotelia . $\quad$ 26, I81, 2 I 4 Arthropodium . . 49, 149 Aseröe . . . . 104 Ash Tree . . . $\quad$. 85 Asplenium . . . 113 Astelia . . . 160,186 Azolla . . . . I 10 Balsam . . . . 69 Barley Grass . . . 190 Barracouta . . 35,98 Bat - . . 73,98 Bees, Humble . 14, 82, 98, 102 ,, Native . . . 56 Beetles . . . I15, 193 Bell-bird . 23, I45, I47, 152 Betaus 193 Bid-a-bid . . . . 74 Birds, Disappearance of . 212
Bitter Cress

PAGE Blackberries . • . 73 Blackbirds

$37,62,71,91,126,141,152$ Black Pine . $\quad 72,185$ Blight Birds . . 39,67 Blue-Bells . . . 49, I 84 Blue Gum . $\quad$. $\quad$. 88 Boletus . . . . 103 Botrychium . . 27, 120 Boulders at Moeraki . $\quad$ I94 Box Thorn . . . I9I Brachyglottis . . . 77 Bramble . . . . 73 Broadleaf . . . 2 I Broom . . 55, 69, 204 Buds . . . . $17 \mathbf{I}$ Bulli-bulli . . . 66,77 Bunting, Cirl • • $\quad 154$ Buttercup . 106, 157, I84, 212 Butterflies . . 68, 83,98, I 17 Cabbage Tree . . $\quad 3^{8}$ Caladenia. . . 49, 213 Calceolaria . . . 148 Canaries, Native . I5I, 2 I 2 Cape Gooseberry . . I9I Caper-Spurge . . . II3 Cardamine . . . $8 \mathrm{I}$ Carduus . . . 190 Carpodetus . . . 46 Carrot, Native . . . 49 Caterpillars . . . 6 Cancalis . . . 190 


\begin{tabular}{|c|c|c|c|c|c|c|c|}
\hline & & & & PAGE & & & PAGE \\
\hline Cedar & - & - & . & 90,184 & Desmoschenus & . & . 113 \\
\hline Celmisia & . & . & . & 49,184 & Dianella . & . & . 27 \\
\hline Centaury & . & . & . & . 66 & Distribution ot & Plants & \\
\hline Chaffinch & . & . & 40 , & $67,1_{54}$ & 10, 19, & 24,27 , & $, 33,74,84$, \\
\hline Chalcococc & & . & . & - $4 I$ & 124,17 & & \\
\hline Cheilanthe & & . & . & . $12 \mathrm{I}$ & Distribution of & Seeds & $54,69,80$ \\
\hline Cherry & & . & . & . $7 \mathrm{I}$ & Doliolum . & . & . $\quad 36$ \\
\hline Chickweed & & . & . & & Dracophyllum & . & . $12 \mathrm{I}$ \\
\hline Chiloglotti & & . & . & 49,213 & Drimys & . & . $\quad 2 \mathrm{I}$ \\
\hline Clathrus & . & . & . & . 103 & Drone Flies & . & . $67,82,98$ \\
\hline Claytonia & . & . & . & . $\quad$ I 57 & Duckweed. & & . $\quad 110$ \\
\hline Clematis & . & . & 2,55 , & $, 85,179$ & Earina . & . & . 66 \\
\hline Clover & . & . & - & - 190 & Earwigs & . & I15, 193 \\
\hline ,, Fer & rtilisa & ation & & & Eels . . & . & . 134 \\
\hline Coast Line & & . & . 1 & 106,112 & Elderberry & . & 55,71 \\
\hline Colour Var & ariation & $\mathrm{n}$ in & Birds & . 166 & Epicarpurus & . & . 119 \\
\hline Convolvulu & & . & • & 31,113 & Epilobium . & . & 85,211 \\
\hline Copepoda & . & . & . & - $\quad 138$ & Eristalis . & . & 82,98 \\
\hline Coprosina & . & 71, & 143, & 172,213 & Erythraa & . & . 66 \\
\hline Cordyline & . & . & . & . $\quad 38$ & Encalyptus & . & . $\quad 88,162$ \\
\hline Coriaria & . & & 72,1 & 183,214 & Euphorbia. & . & . $\quad 113,126$ \\
\hline Corynocar & pus & . & . & - 148 & Euphrasia. & . & . $\quad 49$ \\
\hline Corysanthe & & & 27, & I 19, I 57 & Eyebright . & . & . 49 \\
\hline Crabs & . & . & . I & 100,132 & Fagus . & . & . 127 \\
\hline Crayfish & . & . & . $\mathrm{I}$ & $100,3^{8}$ & Fall of the Lea & f , & . $\quad 75$ \\
\hline Cress & & 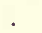 & & 81,190 & Ferns $\quad \cdot 4^{8}$, & $63, \mathrm{IC}$ & 03, I1 2,118 \\
\hline Crow, Nat & tive & . & . & . 212 & Fertilisation of & Flower & rs \\
\hline Cryptozoic & c Faur & & & . 78 & $\mathrm{I}, 9, \mathrm{I} 5, \mathrm{I}$ & $7,23,3$ & $31,124,143$, \\
\hline Cuckoos & . & . 4 & $0,4 \mathrm{I}$ & $, 53,163$ & 145,157, & 160,17 & 79,183 \\
\hline Cupressus & . & . & . & . 88 & Fish, Eggs of & . & . $\quad .139$ \\
\hline Curlew & - & . & . & . 53 & Flax . & . & . 184 \\
\hline Cutting-gr & rass & . & . & . 113 & ,, New Zeala & and & $47,55,211$ \\
\hline Cyanorhan & mphus & & . & . $4 \mathrm{I}$ & Flycatchers, $\mathrm{Fa}$ & antail & \\
\hline Cydonia & . & . & . & 40 & 39,102 & $117, I_{4}$ & $42,151,212$ \\
\hline Cypripedin & & . & . & I8 & Fly, Stinging & . & . $\quad 67$ \\
\hline Cystopteris & & . & . & . 120 & Forstera & . & 49,213 \\
\hline Dacrydium & & . & • & . 185 & Foxglove . & . & . 54 \\
\hline Dactylocne & emis & . & . & - 128 & Frogsmouth & . & 55 \\
\hline Dandelion & & . & , & . 55 & Frost & . & 149 \\
\hline Daucus & . & . & . & 49 & Frost-fish . & . & 133 \\
\hline Dendrobiu & & . & . & II & Fruit Trees & . & 10 \\
\hline
\end{tabular}


PAGE

Fuchsia

$21,55,75,77,102,123,148$ Fungi . . 103, 145, r87 Gastrodia . . . . 120 Gaultheria $\quad 73,183,213$ Gaya. . . . 26, 45 Germination of Seed . . 176 Gerysone . . . . 142 Gnaphalium . . . 2 II Godwit .

Goldfinch . $\quad$. $\quad 39,152$

Gooseberry . . 71, 190

Gorse

55,204

Grafts

Greenfinch

I 2

Griselinia .

Gulls.

Halcyon . . . . 163

Hedge, MIustard . I89 Parsley . . 190

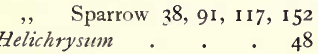

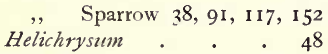
4 I, I 54 - $2 \mathrm{I}$ I 6 ,, Parsley Helophyllum . . 49, 213 Herpolirion . . . 212 Heterograpsus . . 132 Hina-hina

$56,73,120,148,16$ I $, 172,212$ Himeola

- 146 Hoheria . . 44, I80, I9I Hoppers . . 60, I I5, 193 Hordeum . . . . 190 Houhere . . . . 44 Hygrophorus . . . 104 Hymenophyllum . . 119 Hypolepis . . . . 48 Idotea . . . . 108 Impatiens. . . 70 Iris . . . . . 106 Jew's Ear Fungus . . 146 Kaio . . . . I9I Kaka. 47, 66, 72, 122, 151, 212
Kakapo . . . 212

Kamai . . . . 46

Karaka . . . . 148

Kingfisher . . . . 163

Kiwi . . . . 212

Korimako

23, 40, 47, 66, 91, I02, II I $51,163,212$

Kowhai . . IO3, I23, 212

Lagenophora . . . 49

Lamprocolletes . . . 55

Leaf-buds . • . . I7I

Leaf, Fall of the $\quad$. $\quad 75,89$

,, Stomata in . . 25

Lepidium . . . . 190

Lepidopus . . . . $\mathbf{3} 33$

Leucopogon . . I84, 212

Libocedrus. . . . 185

Linnet . . . . I54

Limum . . . . 184

Liverworts - 103, I I8, 2 I0

Lizards . . . 98, 128

Lomaria . . . I05, 210

Longueville Pear . . II

Loranthus . . . . 127

Lyperanthus . . . 213

Macrocystis . . . 130

Magpie . . . I 53

Mako-mako 26, I8I, 21 2, 214

Manuka . . . . 145

Maori Onion . . . 212

Mapau . 21, 160, 172, I 86

Maple . . . 85

Matai . . . 72, 184

Medicago . . . . 190

Melicytus . 56, 73, 120, 148,160 Mentha . . . . 49

Mesembryanthemum

33, I I 3, I I 4,185

Microtis . . . I I, 49

Migration of Birds $\quad$ 40, 4I, 42 


\begin{tabular}{|c|c|c|c|c|c|c|}
\hline \multirow{2}{*}{\multicolumn{3}{|c|}{ Migration of Fishes }} & \multirow{2}{*}{$\begin{array}{r}\text { PAGE } \\
. \quad 35 \\
. \quad 144\end{array}$} & \multirow{3}{*}{$\begin{array}{l}\text { Partridge . } \\
\text { Pear-trees . }\end{array}$} & \multirow{3}{*}{. } & \multirow{2}{*}{$\begin{array}{r}\text { PAGE } \\
\text { - } \quad 155\end{array}$} \\
\hline & & & & & & \\
\hline Mika-mika & & . & . 144 & & & . $\quad 13$ \\
\hline Milk-tree & . & . & . $\quad 119$ & Peat Mosses & . & 213 \\
\hline Mimulus & . & . & 32 & Pepper Tree & . & $21,172,212$ \\
\hline Mint, Nat & ive & . & . $\quad .49$ & Peripatus . & . & 79 \\
\hline Miro & $\cdot$ & . & $72,184,212$ & Petrels . & . & I 16 \\
\hline Miro-miro & . & . & . $\quad 1_{142}$ & Petroica . & - & 39 \\
\hline Mistleto & . & . & $127,160,212$ & Petrolisthes & . & . $\quad 132$ \\
\hline Moon-wor & & . & . $\quad 27,120$ & Pheasant . & . & . $\quad \mathrm{I} 55$ \\
\hline More & . & . & . $\quad 41,152$ & Phormium & . & . 47 \\
\hline Mosses & . & . & $103,118,210$ & Phronima . & . & $35, \quad 135$ \\
\hline Moth & · & . & $7,166,2$ I 4 & Phyllosoma & - & . 100 \\
\hline Mountain & Ash & . & $62,71,221$ & Physalis . & . & . 191 \\
\hline Muhlenbec & kia & . & . $21,26,73$ & Physiculus & · & 35 \\
\hline Munida & . & . & $\begin{array}{ll}\text {. } & \text {. } 98\end{array}$ & Pigeon . & 72,1 & $122,151,212$ \\
\hline Mynah & . & . & . $\quad . \quad{ }^{1} 53$ & Pilchard . & $\cdot$ & $\begin{array}{l}\cdot \quad \\
\cdot \quad 99\end{array}$ \\
\hline Myoporum & & . & $148,162,191$ & Pine Trees & . & 72,184 \\
\hline Myrsine & - & . & $\cdot \quad \cdot 21$ & Pinus & . & . 88 \\
\hline Myrtle & . & . & . 47 & . & . & . $\quad 41,142$ \\
\hline Myrtus & . & . & 47,120 & Piri-piri . & . & - $56,74,84$ \\
\hline Nertera & . & . & . $\quad 210,213$ & Pittosporum & $\cdot$ & . $\mathrm{I} 59, \mathrm{I} 86$ \\
\hline Nestor & . & . & . $\quad 47$ & Plagianthus & . 26, & $45,122,180$ \\
\hline Nettle & . & . & $\cdot \quad \cdot 8_{3}$ & Plover . & $\cdot$ & $\cdot \quad \cdot$ \\
\hline Ngaio & . & . & $148,162,191$ & Plum. . & . & . $\quad 71$ \\
\hline Ninox & . & . & . $\quad 4^{1}$ & Podocarpus & . & 72,185 \\
\hline Norway M & Aaple & . & 55 & veed. & . & . 110 \\
\hline Nyctemera & $x$ & . & 7 & Poplars . & . & 85,143 \\
\hline Octopus & . & . & . 98 & Poppy & . & . 55 \\
\hline Olearia & . & . & . 184 & Porcellio . & $\cdot$ & $\begin{array}{ll}. & \\
\text {. } & 59\end{array}$ \\
\hline Ophiogloss & sum & - & 27,120 & Poro-poro . & 66 & $71,148,212$ \\
\hline Orchestia & · & . & . $\quad . \quad 59$ & Porpoise . & . & . $\quad 99$ \\
\hline Orchids8, & 50,66 & I 19 , & $9,157,210,212$ & Potato - & . & . 13 \\
\hline Owls & . & . & $\cdot \quad 4 \mathrm{I}$ & Prasophyllum & . & I I, 49 \\
\hline Oxalis & . & . & $76,119,210$ & Pratia & . & . 49 \\
\hline Panax & $\cdot$ & $\cdot$ & $21,145,172$ & Prawns & . & 193 \\
\hline Parakeet & - $4 \mathrm{I}$ & ; 47 , & $66,152,212$ & Primrose : & . & - \\
\hline Paramith, & & $\cdot$ & . $\quad .132$ & Prosthemadera & & 23 \\
\hline Parson Bir & & . & - 23 & Protective Colou & uring & - 130 \\
\hline Parsonsia & . & . & 85,162 & Pterostylis. & . & . 9,49 \\
\hline
\end{tabular}


PAGE

Puccinia . . - . $\mathrm{I} 87$

Puzzle Monkey . . . 9I

Quail

155,212

Rabbits

I 68

Ragwort

Rangiora

Ranunculus

Raoulia

Red Cod

,Pine

, Pole

Rhipidura.

Rhopalostylis

Ribbon-fish

-wood 26, 44, 75, 77, 180

Robin, Native . I 5 I, I63, 2 I 2 Redbreast . 67, I55

Rock-pools

- 130

Rowan

$62,7 \mathrm{I}$

Rubus

Ruppia

Saddlebacks

73,145, I6I

Salius

Salpa

Sandhills

Sandpiper .

Sarcochilus

Sceloglaux .

Scirpus

Seaweed

Sea Wrack

Sedges

Seed, Germination of .

$84,113,213$

Senecio . . 7, $48,148,2$ II

Sequoia

Shamrock. . . . 70

Shrimps

Sisymbrium
Skylarks

PAGE

Snipe.

40, $102,152,165$

Snow

Snowberry .

Solanum

Sophora

26, 90, I 47

$73,183,211$

Sparrows.

66, 7 I

Sparrows

- 123

Speargrass .

$37,152,166$

Sphagnum .

- 2 II

Spiders

- 213

Spinach, N. Z. .

. IO. 42 , II 5

Spores

34

Squirting Cucumbers . $\quad 70$

Starling

38, I 52,2 I 4

Stellaria

- 215

Stick-insect . . . 105

Stinkwood. • . 71, I44

Stomata . . . . 25

Stomoxys . . . . 67

Succulent Fruits 25, 126

Swans, Black . . . 155

Tetragonia. . . . 34

Thelymitra . . 49, 212

Thistles . . $55,85,190$

Thrush

$37,62,7$ I, 91, I17, 1 26, 141, I47, I 52, I 64

Thrush, Ground. ․ 212

Thrysites . . . . 35

Tipari . . . . I9I

Tits 39, IO2, I I 7, I42, I 5 I, 2 I 2

Tomahawk Lagoon . . IO5

Totara . . . $72, \mathbf{1} 84$

Trifolium . . . . 190 Tui

23, 40, 48,66, I 52, I 62, I64, 2 I 2 Tupeia $\quad . \quad \therefore 127,160$ Tutu . 27, 72, 162, I82, 21 2, 214 


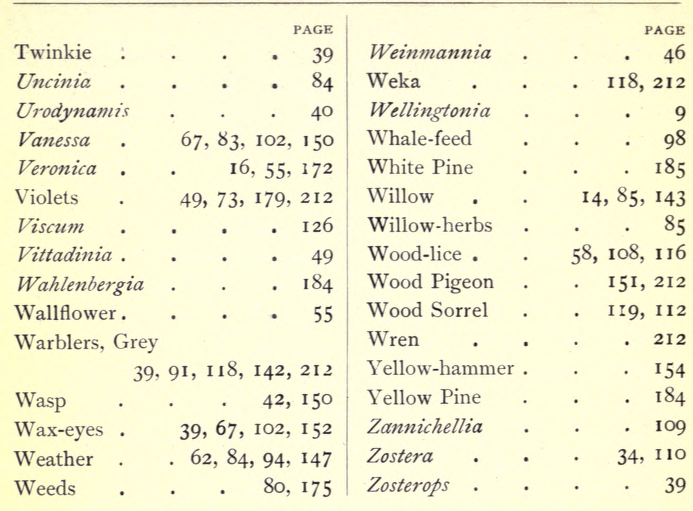


UNIVERSITY OF CALIFORNIA LIBRARY

\section{Los Angeles}

This book is DUE on the last date stamped below.

IDPG 971 REC'D LD-URL

谒

\section{DEC1019974}

Wish JUN L 1902

แมพ 171982 


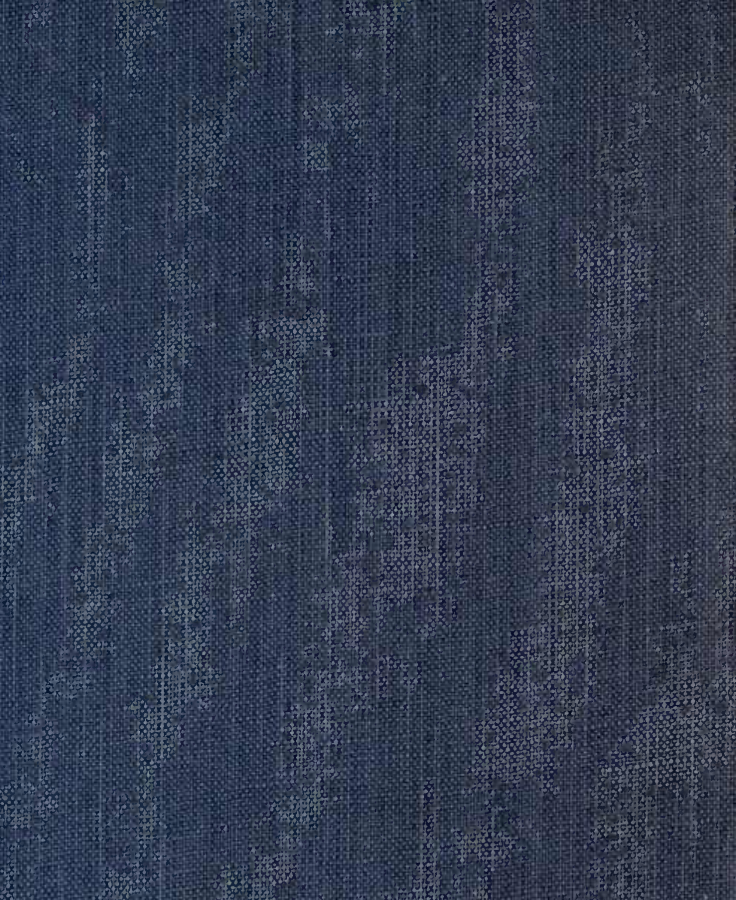

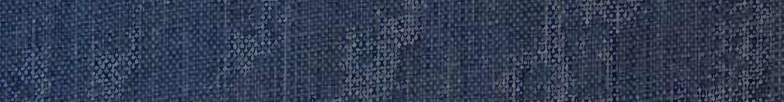

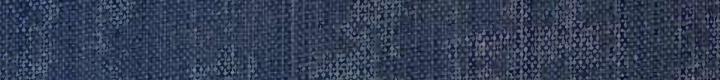

1.

H.

y.t.

Q

\begin{tabular}{|c|c|c|c|c|}
\hline & &
\end{tabular}

\begin{tabular}{|c|c|c|c|c|}
\hline & &
\end{tabular}

2.

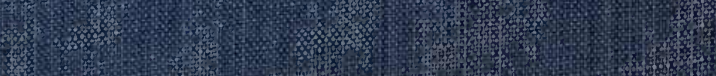

* 